\title{
IG \\ Understanding Migration Aversion Using Elicited Counterfactual Choice Probabilities
}

\author{
Gizem Koşar \\ Tyler Ransom \\ Wilbert van der Klaauw
}

Working Paper 2019-037

$06 / 2019$ 


\title{
Understanding Migration Aversion using
}

\section{Elicited Counterfactual Choice Probabilities*}

\author{
Gizem Koşar $^{\dagger} \quad$ Tyler Ransom ${ }^{\ddagger} \quad$ Wilbert van der Klaauw ${ }^{\S}$
}

March 31, 2019

\begin{abstract}
Residential mobility rates in the U.S. have fallen considerably over the past three decades. The cause of the long-term decline remains largely unexplained. In this paper we investigate the relative importance of alternative drivers of residential mobility, including job opportunities, neighborhood and housing amenities, social networks and housing and moving costs, using data from two waves of the NY Fed's Survey of Consumer Expectations. Our hypothetical choice methodology elicits choice probabilities from which we recover the distribution of preferences for location and mobility attributes without concerns about omitted variables and selection biases that hamper analyses based on observed mobility choices alone. We estimate substantial heterogeneity in the willingness-to-pay (WTP) for location and housing amenities across different demographic groups, with income considerations, proximity to friends and family, neighbors' shared norms and social values, and monetary and psychological costs of moving being key drivers of migration and residential location choices. The estimates point to potentially important amplifying roles played by family, friends, and shared norms and values in the decline of residential mobility rates.
\end{abstract}

JEL Classification: J61, R23, D84

Keywords: Migration, Geographic Labor Mobility, Neighborhood Characteristics

\footnotetext{
*Nicole Gorton provided excellent research assistance. We are thankful to participants at the 2nd IZA Junior/Senior Symposium (Austin, TX), the 2018 European Society for Population Economics meetings, the 2018 European association of Labour Economists meetings, the 2018 Workshop on Subjective Expectations and Probabilities in Economics (CESifo Group Munich) and seminar participants at Ohio State University for valuable comments. The opinions expressed herein are those of the authors and not necessarily those of the Federal Reserve Bank of New York or the Federal Reserve System. All errors are our own.

†Federal Reserve Bank of New York. E-mail address: gizem.kosar@ny.frb.org

$\ddagger$ Oklahoma and IZA. E-mail address: ransom@ou.edu

$\S$ Federal Reserve Bank of New York and IZA. E-mail address: wilbert.vanderklaauw@ny.frb.org
} 


\section{Introduction}

Residential mobility rates in the U.S. have fallen steadily over the past three decades. While $19.6 \%$ of U.S. residents changed residence within the United States in 1985, only $9.8 \%$ did so in 2018, its lowest level since 1948 when the Census Bureau began tracking mobility. ${ }^{1}$ As shown in Figure 1, the decline in the annual mobility rates - which actually seems to have started sometime before the most recent peak in 1985-has been persistent through business cycles and has occurred at different levels of geographic detail. While $3.0 \%$ and $6.5 \%$, respectively, moved to a different state or county in 1985 , only $1.5 \%$ and $3.6 \%$ did so in 2018. Mover rates within the same county also declined from $13.1 \%$ in 1985 to $6.2 \%$ in 2018.

There is growing concern about the implications of declining mobility for labor market efficiency, economic dynamism, and economic growth. The dynamic reallocation of resources is important for productivity growth, requiring labor and other resources to be able to move from low productivity places to high productivity places. Moreover, given the importance of migration for upward mobility, the especially large declines seen in residential mobility among lower skilled workers, with many no longer willing or able to leave declining urban and rural areas, is particularly worrisome and is likely contributing to reduced economic mobility, increased inequality, political polarization and the growing urban-rural divide.

Rather than being reasons for moving, poverty and low incomes may become reasons for not moving, contributing to increased geographic sorting with a concentration of high-skilled workers in high-wage, high-cost states and low-skilled workers in low-wage, low-cost states (Ganong and Shoag, 2017). Declining mobility may also be consequential for persistence in poverty and intergenerational mobility and inequality, given the importance of neighborhood effects on child development early in childhood (Chetty and Hendren, 2018a,b; Chetty, Hendren, and Katz, 2016). Evidence suggests that increased opportunities for families to move to wealthier areas may improve upward mobility while also being cost-effective (Chetty, Hendren, and Katz, 2016).

The causes of the long-term decline in mobility remain largely unexplained. A sizable and

\footnotetext{
${ }^{1}$ While there exists variation in computed mobility rate levels based on different data sources, they all show a declining long-term trend (Molloy, Smith, and Wozniak, 2011; Kaplan and Schulhofer-Wohl, 2012).
} 
growing number of studies, focused primarily on interstate migration, have investigated the role of changes in demographics, housing and labor market characteristics, location-based government policies and changes in cultural values and norms.

In this paper, we investigate determinants of migration and residential location choices using a novel empirical approach in the migration literature. We use two waves of the New York Fed's Survey of Consumer Expectations (SCE) to accomplish two separate but related purposes: $(i)$ to measure general migration attitudes; and $(i i)$ to elicit location choice probabilities in several hypothetical scenarios. ${ }^{2}$ We use the migration attitudes to measure people's propensity to move, such as by asking them to classify themselves as "mobile," "stuck," or "rooted" (Florida, 2009). We use the elicited probabilities to estimate individual preferences for various attributes of location choice and allow preferences to take on unrestricted forms of heterogeneity. ${ }^{3}$ We use our preference estimates to quantify the importance of each attribute by computing individuals' willingness-to-pay (WTP) for each.

Our main findings are that individuals face substantial non-pecuniary costs to moving (over $100 \%$ of annual income on average), and that they also place high value on proximity to family (30\% of income) and on agreeableness of local social and cultural norms (11\% of income). Preferences are markedly heterogeneous across demographic groups in ways that conform well with economic theory and previous empirical findings in the literature. For example, psychological moving costs and preferences for family and local norms all increase with age and residency tenure. Psychological moving costs are remarkably large for a nontrivial fraction of the population.

Unlike existing studies which rely on revealed preference data, our approach is to investigate the importance of various determinants of migration and residential choice decisions using a stated preference approach. This approach has important advantages over existing methods in measuring individual preferences and the willingness to pay for various housing and location attributes. Our approach addresses the simultaneous nature of household deci-

${ }^{2}$ This type of analysis has been successfully used in the industrial organization (Blass, Lach, and Manski, 2010) and labor and education literatures (Arcidiacono, Hotz, and Kang, 2012; Arcidiacono et al., 2014; Wiswall and Zafar, 2015, 2018), but not to our knowledge in the migration literature.

${ }^{3}$ Our hypothetical scenarios cover many of the proposed determinants of location choice and mobility, including income, housing costs and attributes, local amenities, and non-market factors such as proximity to family, agreeableness of local cultural norms, and psychological costs of moving. 
sions regarding community choice and housing services, capturing the influence of personal and site characteristics jointly. Furthermore, our choice model captures the likely dependence between the decision to stay or move away from a specific home and community and the decision to move to a particular community, by jointly modelling the decision of moving and destination.

Assuming that preferences are stable over time, our findings that individuals place substantial value on family and local norms suggest that these factors may be acting as migration multipliers. That is, a secular decline in migration (for any of a variety of reasons) would reduce a household's migration likelihood, but would also reduce the migration likelihood of that household's family and friends, as well as of those who share similar social values. Thus, the secular decline operates through both direct and indirect channels. ${ }^{4}$

The remainder of this paper proceeds as follows. The next section details existing explanations for the decline in migration and places our findings in the previous literature. Section 3 describes our data, reports descriptive statistics, and introduces our experimental setup. Section 4 describes our model and estimation method. Section 5 presents our findings on location and mobility preferences and explores the willingness-to-pay for different location attributes. The final section offers concluding remarks.

\section{Background \& Related Literature}

This section provides further background on previously proposed reasons for the decline in migration, as well as where our study fits into the literature on internal migration in the United States.

\subsection{Reasons for the decline in migration}

In recent years a large and growing number of studies have investigated potential reasons for the long-term decline in mobility. The role of demographic changes in age, education, and household structure were analyzed by Molloy, Smith, and Wozniak (2011) and Kaplan and Schulhofer-Wohl (2012). As mobility rates decline at older ages, the general aging of

\footnotetext{
${ }^{4}$ See Karahan and Rhee (2017) who explore migration spillovers of aging.
} 
the population has contributed to the mobility decline, but the shift in the age distribution can only explain a modest part of the observed decline. ${ }^{5}$ Mangum and Coate (2018) propose an alternative demographic explanation: migration has decreased at different rates across locations in the US. Cities with historically high population turnover traditionally had fewer residents born in that location. As migration has declined, and as the in-migrants to highturnover areas have put down roots and had children, these historically high-turnover areas have seen an increase in the fraction of their residents that are born there. This secular increase in "rootedness" of these locations has caused them to have lower turnover. Multiplied over many high-turnover areas, Mangum and Coate (2018) conclude that this channel of rising "rootedness" explains nearly half the decline in migration.

Housing-related factors include the growing geographic divergence in the growth of housing costs, and the contributing roles of zoning laws and land use regulations in limiting the supply of housing in some of the most innovative and productive cities, driving up home prices and making moving there unaffordable (Ganong and Shoag, 2017; Hsieh and Moretti, forthcoming). Additional proposed explanations involving the housing-market include the role of home-lock in the wake of the housing bust that left many homeowners with negative home equity (Chan, 2001; Ferreira, Gyourko, and Tracy, 2010; Modestino and Dennett, 2013; Foote, 2016; Bricker and Bucks, 2016), and location-dependent government housing subsidies through mortgage interest tax credits and low-income housing support (Schleicher, 2017). Other location-dependent benefit programs, such as Medicaid and welfare benefits that vary across states, may also have played a role.

Among labor market-related factors, attention has been paid to the role of two-earner households, job-lock associated with rising health care costs, the expansion of telecommuting and flexible work schedules, and an increase in state-level occupational licensing and reduced transferability of seniority across states (Molloy, Smith, and Wozniak, 2014; Johnson and Kleiner, 2017; Kaplan and Schulhofer-Wohl, 2017). According to a White House (2015)

\footnotetext{
${ }^{5}$ A recent paper by Karahan and Rhee (2017) finds that while the direct effect of an aging population accounts for 20 percent of the decline in interstate migration decline, there are additional migration spillover effects. They argue that as older workers have higher moving costs the increase in their share in the local labor market causes local firms to recruit and hire more heavily in that market, thereby raising the local job finding rate and lowering the mobility of all workers in that local labor market. Their analysis suggests that when these equilibrium effects are incorporated, population aging can explain a somewhat larger share of the mobility decline.
} 
report, more than $25 \%$ of the U.S. workforce in a wide range of occupations-including lawyers, doctors, teachers, barbers, cosmetologists, bartenders, florists - were covered by state licensing laws by 2008, with the rate having grown roughly five-fold since 1950s.

Other proposed labor-market related explanations include a decline in American geographic specialization and diversity in production, and a convergence in job opportunities that reduces the need to move to another state for a job (Kaplan and Schulhofer-Wohl, 2017). A general decline in job switching (Davis, Faberman, and Haltiwanger, 2012; Hyatt and Spletzer, 2013), with job reallocation rates having fallen more than a quarter since 1990, also represents a potential contributing factor to reduced mobility, although the reason for the decline in job switching is itself unclear (Molloy, Smith, and Wozniak, 2014).

Finally, rising student debt and its positive impact on parental co-residence may also have played a role in declining mobility (Bleemer et al., 2017), as well as several cultural changes including increased geographic segregation of people by beliefs and political views, changing attitudes about living in cities, suburbs, and rural areas, and an increased importance of or reliance on extended network of friends, family, and church.

Except for potentially important roles for aging, rising "rootedness" and changes in the labor market, strong support appears lacking for the relevance of most factors in explaining the broad-based longer-term decline in mobility over the past decades. Migration rates have fallen since the 80s for nearly every sub-population: within age, gender, race, income, home-ownership status, marital status, own and spouse employment status. Moreover, the composition of the population has not shifted in a way that would affect aggregate migration appreciably (Molloy, Smith, and Wozniak, 2011, 2014). ${ }^{6}$ While the declines in job- and employer switching and migration appear related, current evidence on this interrelationship, as well as on the roles of most factors discussed above is based primarily on analyses of interstate mobility. The similarly large declines in geographic mobility within state and within counties suggest that there are other drivers besides aging and job changing at work.

The absence of clear predominant driver(s) is consistent with relative stability in the reasons respondents provide in the CPS for moving since 1999. Figure 2 shows a slight increase

\footnotetext{
${ }^{6}$ For example, the share of households with two earners has been quite stable over the last 30 years, and while increasing, only $2.9 \%$ of workforce in 2017 worked from home at least half of time.
} 
in the share moving for family- and employment related reasons and a slight decline in moving for housing-related reasons. Figure A1 in the appendix provides a further breakdown of work-related factors, such as a job transfer or job loss, and wanting to be closer to work. Housing factors include wanting to own a home rather than rent, seeking a better home or better neighborhood, or wanting cheaper housing. Additional mobility factors include changes in marital status or wanting to establish one's own household. Again, we see no clear shift in reasons for moving between 1999-2018 except a slight increase in the share moving to establish their own household and declines in the shares wanting to move for a new or better home or because of wanting to own instead of rent.

\subsection{Internal migration literature}

Our study relates to the extensive economics literature on the determinants of migration and residential location choice. To our knowledge, all previous studies make use of observational data at either the aggregate, individual, or household level. Our study contributes to this literature by providing preference estimates based on an individual-level stated-preference choice experiment, which we detail in the next section.

Much of the econoimes migration literature has focused primarily on the importance of employment opportunities and job search in the decision to move or stay in a current location. Bartel (1979) studied the relationship between migration and job mobility, while Tunali (2000) investigated the earnings-enhancing benefits of migration by analyzing movestay decisions without distinguishing between different destinations. Dahl (2002) extended this analysis by incorporating the choice of state to move to as a one-time lifetime migration decision. Kennan and Walker (2011) extended the analysis further to a fully dynamic discrete choice model of migration to different states, focusing on forward-looking households with expected income as the main economic influence on migration. While their estimates show the importance of income prospects in migration decisions, they also find that, despite large potential income gains, most individuals do not migrate due to large estimated migration (utility) costs. Moreover, while young, welfare-eligible women are found to be responsive to income differences in their migration decisions, they find that even large differences in welfare benefit levels provide surprisingly weak migration incentives (Kennan and Walker, 
2010). ${ }^{7}$ Gemici (2011) further extended this dynamic framework by modeling migration as an optimal joint job search problem for married couples, with different locations defined as census divisions.

While early research on residential location choice relied mainly on aggregate-level data, most modern research has used individual- or household-level data to describe residential location choices using the discrete choice framework of McFadden (1978). Residential alternatives in these studies are characterized by the characteristics of residential units (unit cost/value; unit size; housing type) and location attributes (including population density, school quality, crime, housing costs, labor market opportunities, property and income tax rates, transportation network). For example, Quigley (1976) studies the role of housing characteristics in determining a household's location choice, while Quigley (1985) and Rapaport (1997) analyze the importance of public services. Nechyba and Strauss (1998) investigate roles of community characteristics and local public services, including public school spending. Similarly, Bogart and Cromwell (2000) analyze the impact of schools on the residential location decision of households. Cullen and Levitt (1999) investigate the responsiveness of location choice to differences in crime rates. Several studies have analyzed the importance for location choice of preferences for the average characteristics of residents in a location. Bajari and Kahn (2005) estimate the willingness to pay for housing attributes and community attributes, including the share of black households and share of college educated households in the location. Similarly, Bayer et al. (2016) adopt a dynamic framework that provides estimates of the marginal willingness to pay for several non-market amenities including neighborhood air pollution, violent crime and racial composition. Bayer, Ferreira, and McMillan (2007) uses a similar framework to estimate household preferences for school and neighborhood sociodemographics in the presence of sorting.

In addition to housing and neighborhood characteristics, a number of studies of location choice have examined the importance of income and employment opportunities and of demographic factors. Chen and Rosenthal (2008) consider the role of job opportunities, and more generally high-quality business environments on residential location choices of singles and

\footnotetext{
${ }^{7} \mathrm{~A}$ recent paper by McCauley (2018) attributes the lack of welfare-induced migration to a general lack of awareness of differences in welfare benefits across locations.
} 
couples over the life cycle. Clark and Onaka (1983) and Nivalainen (2004) analyze changes in residential location choice through the life cycle, with changes in household size, ages of household members, and marriage status. Malamud and Wozniak (2012) show that earning a college degree increases one's likelihood of moving. Several studies include the household's previous location and distance from the current location as determinants, capturing a preference for proximity to the previous location, or through reference-dependent preferences (de Palma, Picard, and Waddell, 2007; Habib and Miller, 2009; Kennan and Walker, 2011). Similarly, a number of studies have tried to capture a desire to maintain social contacts, by including distance to social contacts as a determinant (Gordan, 1992; van de Vyvere, Oppewal, and Timmermans, 1998).

Finally, a recent and growing number of studies have looked at the role of regional economic shocks on migration. Yagan (2014, Forthcoming) examines migratory responses to the Great Recession shock, while Bartik (2018) analyzes the impact of two specific economic shocks (trade exposure with China and the fracking boom), and Wilson (2018a,b) focuses on migratory behavior and information frictions in response to the fracking boom. Oswald (2018) and Ransom (2019) each incorporate regional economic shocks into the Kennan and Walker (2011) dynamic framework. ${ }^{8}$

While adopting a different approach, our analysis incorporates many of the determinants of migration and location choice decisions discussed in the studies above. Unlike most previous studies we account for the simultaneous nature of location choice and mobility decisions, and their dependence on community and housing characteristics and moving costs.

\section{Data}

To describe our approach and findings, in this section we begin with an outline of the data set used in our analysis, present descriptive patterns, and explain our experimental setup.

\footnotetext{
${ }^{8}$ Oswald (2018) focuses on the decision to buy versus rent a house (and estimates moving costs separately for owners and renters), while Ransom (2019) focuses on job search frictions (and estimates moving costs separately by employment status).
} 


\subsection{Survey of Consumer Expectations}

Our data come from the New York Fed's Survey of Consumer Expectations (SCE), which is a monthly online survey of a rotating panel of individuals. ${ }^{9}$ The survey is nationally representative and collects data on demographic, household, education, health, and economic variables for a sample of household heads. It also elicits individual expectations about macroeconomic and household-level outcomes related to inflation, the labor market, household finance, and other variables. Each month, approximately 1,300 people are surveyed. Respondents participate in the panel for up to 12 months, with a roughly equal number rotating in and out of the panel each month. Our data set uses two waves of the SCE: January and September 2018. In those waves we supplemented the core SCE questionnaire with a special survey module designed to study migration and residential location decisions.

Our survey module first asks respondents about their most recent move and their probability of moving within the next two years. It then asks respondents to rate the relative importance of several determinants of migration and location choice decisions, asking separately about factors in favor of and against moving over the next two years. ${ }^{10}$

In contrast to these qualitative measures of relative importance, we then designed a set of questions as part of a choice experiment to obtain a quantitative assessment of importance. ${ }^{11}$ Specifically, we collect data on individuals' probabilities of choosing from a set of hypothetical locations, including their current location. We experimentally vary the characteristics of the locations in order to identify individuals' preferences for various location attributes. The attributes that we vary are those known to affect migration and residential location choice: income prospects, housing costs, proximity to family and friends, taxes, community social norms, crime, and "box and truck" moving costs. The answers to these questions can then be used to measure the willingness to pay, or required compensation costs, for different location attributes.

We elicit preferences for migration and residential location using two different choice

\footnotetext{
${ }^{9}$ The survey is conducted on behalf of the Federal Reserve Bank of New York by the Demand Institute, a non-profit organization jointly operated by The Conference Board and Nielsen. Armantier et al. (2017) provides a detailed overview of the sample design and content of the survey.

${ }^{10}$ These two questions were asked only in the January wave.

${ }^{11} \mathrm{~A}$ full list of our supplemental questions is available in Online Appendix B.
} 
experiments. In one experiment, individuals are asked to consider among three destination neighborhoods in a hypothetical situation where they cannot stay in the current location and have to move. In a second experiment, individuals are asked to consider their status quo relative to two alternative options, each of which would necessitate a move.

Before discussing the experiments in greater detail, we first present some descriptive evidence on the representativeness of our sample, and how migration considerations and expectations vary across individuals.

\subsection{Descriptive patterns}

In Table 1, we list characteristics of our SCE sample compared with the 2017 American Community Suvey. From a demographic standpoint, our sample matches up well with the general US population of household heads. ${ }^{12}$ Some $35 \%$ of household heads are college graduates while $70 \%$ own the home they live in. In addition to demographics and education, we also collect information on individuals' health status. About half of our sample classifies themselves as being in very good or excellent health. Prior to moving to the current residence, $64 \%$ lived in the same county, $20 \%$ lived in the same state but different county, and $16 \%$ lived in a different state. Finally, following Florida (2009) we ask people to classify themselves by their ability and willingness to move, as being "mobile," "stuck," or "rooted." "Mobile" individuals consider themselves to be open to, and able to move locations if an opportunity comes along, while "rooted" individuals consider themselves strongly embedded in their community and able but unwilling to move. "Stuck" individuals have a desire to move but face insurmountable constraints in doing so. ${ }^{13}$ Just under half of our sample reports being rooted, while just over one third classifies themselves as mobile and about one in seven classify themselves as being stuck.

In addition to matching well the demographic and economic distribution of the United States population, our sample also matches well the migration distribution. Specifically, we

\footnotetext{
${ }^{12}$ For further details on the representativeness of the SCE, see Armantier et al. (2017).

${ }^{13}$ The precise wording of the question, which was asked at the very end of the interview, was "In terms of your ability and willingness to move, which of the following best describes your situation? [Please select only one]. Mobile - am open to, and able to move if an opportunity comes along; Stuck - would like to move but am trapped in place and unable to move; Rooted - am strongly embedded in my community and don't want to move.
} 
document low observed and expected migration rates, and migration rates that decline with distance. In Table 1, we find that $15 \%$ of household heads changed residence in the past year, compared with $13 \%$ in the ACS. In Figure 3, we show the distribution of individuals' self-reported likelihood of moving within the next two years. Nearly $25 \%$ of the sample report a $0 \%$ chance of moving while $5 \%$ report a $100 \%$ probability of moving. The median person reports a $10 \%$ chance of moving, with the average person reporting a $25 \%$ chance of moving. The average and median subjective likelihood of moving is in the same range as the observed actual frequency of moving.

In Table 2, we examine the self-reported probability of moving and other demographic characteristics of those self-identified as mobile, stuck, and rooted. As expected, those who identify themselves as rooted have the lowest average subjective migration likelihood (15\%), while those who report being mobile have the largest average subjective likelihood of moving over the next two years $(39 \%)$. The rooted tend to be disproportionately white, older, married, and homeowners, and also are more likely to live in rural areas. The rooted and stuck are also more likely than the mobile to live within 50 miles of family. Those who report being stuck have lower education and worse health and are more likely to live in cities. Interestingly, the mobile and the rooted have similar levels of education and income, although those mobile are more likely to live in cities.

To get a sense qualitatively of different reasons for why people may not want to move, we asked respondents to rate the importance of a set of possible reasons for not moving to a different primary residence over the next 2 years, on a rating from 1 (not at all important) to 5 (extremely important). Table 3 shows the number of respondents who find each factor very (4) or extremely important (5), ordered from highest to lowest average importance in our overall sample. Among the factors rated most important for not moving are satisfaction with the current home, neighborhood and job, proximity to family and friends, the unaffordability and undesirability of alternative locations, and a high perceived cost of moving. Several determinants discussed in the literature, such as state licensing requirements, a potential loss of welfare benefits, mortgage rate lock-in, and difficulty in qualifying for a new mortgage are rated low on average as factors for not moving. Those self-identified as rooted rate satisfaction with their current home and neighborhood, living near family and friends, and 
involvement in local community or church as the most important reasons for not moving. In contrast, those who describe themselves as stuck rate the unaffordability of homes in alternative locations, the high cost of moving, and difficulty in qualifying for a new mortgage as more important, compared to the other two groups. They also express less satisfaction with their current job and are less optimistic about job prospects elsewhere.

In Table 4 we asked respondents to similarly rate the importance of various factors as reasons in favor of moving to a different residence over the next two years. Improvements in home quality and affordability, a desire to live closer to family and friends, a more desirable and safer neighborhood, and better jobs are considered most important. Gaining Medicaid coverage, higher welfare benefits and reductions in commuting time are considered relatively less important. Those self-identified as mobile on average rated a more desirable neighborhood, job opportunities and improved local amenities higher, while those stuck rated reducing housing costs as a more important reason for moving. Finally, those identified as rooted rated all factors as less important reasons for moving to another residence.

A comparison of the levels of importance in Tables 3 and 4 sheds light on migration attitudes in the US. The average respondent has much stronger views about reasons not to move than about reasons to move. Additionally, the large number of reasons that are rated as important by at least $20 \%$ of respondents points to the multidimensional motivations and high degree of preference heterogeneity in migration decisions. We now describe our experiment which is able to appropriately measure such preference heterogeneity.

\subsection{Experimental Setup}

An important drawback of qualitative measures of relative importance of reasons to move or not move is that different respondents may use different rating scales, impeding interpersonal comparisons. In order to assess the quantitative importance of different determinants of migration and residential location choice decisions on a common interpersonally comparable scale, we use a hypothetical stated choice methodology to estimate preferences for different migration and location choice attributes (Blass, Lach, and Manski, 2010). More specifically, we ask respondents to assign a probability of choosing among a fixed set of alternatives. The elicitation of choice probabilities provides respondents an ability to express uncertainty 
about future behavior while simultaneously allowing individuals to rank their choices, providing more information than if they had been asked only about their most preferred choice alternative.

Importantly, as will be discussed in the next section, our approach permits identification of the distribution of preferences under weak assumptions about the form of preference heterogeneity. Furthermore, no explicit assumptions need to be made about the equilibrium migration outcome mechanisms. Perhaps most importantly, unlike revealed preference approaches to identifying preferences from observed migration and location choice behavior, our approach avoids omitted-variables and endogeneity biases due to unobserved location attributes or circumstances that are correlated with any included observed characteristics.

Before we describe our approach for estimating preferences using stated choice data, we first discuss the experimental setup used. In the first experiment (fielded in the January wave) respondents are asked to consider three destination neighborhoods in a hypothetical situation where they cannot stay in the current location and have to move. We provided a total set of 16 different choice scenarios, of which respondents are randomized to answer eight.

More specifically, in the January survey we ask a respondent to imagine the situation where she/he were forced to move today to a location some 200-500 miles away, and had to decide which neighborhood to live in, in which they would intend to stay for at least 3 years. ${ }^{14}$ In each scenario, the respondent is given a choice among three neighborhoods and asked to report the percent chance (or chances out of 100) of choosing each neighborhood. Across the different choice scenarios, we exogenously vary different attributes associated with the three choice locations, including the cost of housing, local crime rate, state and local tax rates, the household's income prospects, distance from current location, "box and truck" moving costs to the new location, home quality as measured by the size of the home (square footage), agreeableness of local cultural values and norms, and family and friends moving with to the new location. While varying a limited set of attributes, respondents are told that all locations are identical in all other aspects. Two such choice scenarios are shown in

\footnotetext{
${ }^{14}$ Those who currently own their home are asked to assume that they are able to sell their current primary residence today and pay off their outstanding mortgage (if they have one).
} 
Figure 4.

Similarly, the second experiment (fielded in the September wave) contains 24 different choice scenarios, of which respondents are randomized to answer 16. Unlike the scenarios presented in the January 2018 survey, respondents were given the option to remain in their current location as one of the three choice alternatives. More precisely, participants are told that "In each of the scenarios below, you will be shown three locations to live in where each is characterized by: [3 different migration or location attributes]. Suppose that the locations are otherwise identical in all other aspects to your current location, including the cost of housing. In each scenario, you are given a choice among three neighborhoods and you will be asked for the percent chance (or chances out of 100) of choosing each. Neighborhood A represents your current location." Two such choice scenarios are shown in 5.

In total, our sample includes 1,988 different individuals and either 8, 16, or 24 choice scenarios. 237 individuals participate in both waves of the survey and respond to 24 choice scenarios. ${ }^{15}$ A summary of the distribution of person-scenarios is included in Table A1 in the Online Appendix.

Figure 6 lists distributions of the subjective choice probabilities by SCE wave. Panels (a) and (b) show that probabilities tend to be rounded to numbers ending in 0 or 5 , as well as mass points at 0 and 100. Panels (c) and (d) report the average tendency to choose each alternative in each wave, averaged across individuals and scenarios. Panels (a) and (b) show that our estimation will need to be robust to rounding errors. Panels (c) and (d) show that our estimation should include fixed effects for the order of the alternative shown as a way capture respondents' tendency to assign more probability to certain alternatives based on the order, regardless of the alternative's characteristics. Finally, the large mass on alternative 1 in panel (d) signifies that moving is costly, since alternative 1 in the September wave always corresponds to staying in the current location.

Overall, our descriptive results show that location preferences and likelihood of moving contain a great deal of heterogeneity. In particular, preferences and behavior appear to starkly differ across the "mobile," "stuck," and "rooted" groups, and there are many reasons

\footnotetext{
${ }^{15}$ Participation in the migration survey module was restricted to those who had participated in the SCE at least once.
} 
to move and not to move that are rated as important by at least $20 \%$ of our sample. The model that we introduce in the next section will account for heterogeneity across individuals in preferences for location. Estimation of the model will also account for rounding of probabilities and potential alternative-order effects across different choice scenarios.

\section{Model \& Estimation}

This section introduces our theoretical and empirical framework for estimating location preferences from hypothetical choice sets. We first introduce a canonical random utility model, followed by our empirical model which makes use of the hypothetical choice data that we have collected. We then discuss how the model's parameters are identified and describe our estimation procedure.

\subsection{Random utility model of migration and neighborhood choice}

We now consider a model of location choice, where individuals are indexed by $i$ and locations are indexed by $j$. Utility is a function of $X_{j}$, which is a vector of attributes describing the location, and $M_{j}$, which is an indicator equal to unity if choosing $j$ requires moving and zero otherwise. Utility for a given location is also a function of an idiosyncratic preference shock $\varepsilon_{i j}$, which captures any additional location-specific preferences of individual $i$ for location $j$. The idiosyncratic part of the preferences is observed by the decision maker at the time of the choice decision, but not by the econometrician. This idiosyncratic term reflects all the remaining attributes that might affect the preferences. We assume that preferences take the usual linear-in-parameters form with additive separability between the observed attributes and idiosyncratic shocks:

$$
u_{i j}=X_{j} \beta_{i}+\delta_{i} M_{j}+\varepsilon_{i j},
$$


where $\beta_{i}$ is a vector of individual-specific preference parameters and $\delta_{i}<0$ represents the fixed cost incurred from mobility with $M_{j}$ defined by:

$$
M_{j}= \begin{cases}1 & \text { if distance }>0 \\ 0 & \text { otherwise }\end{cases}
$$

An individual $i$ makes a location choice after observing attributes $X_{1}, \ldots, X_{J}$ and $\varepsilon_{i}=$ $\varepsilon_{i 1}, \ldots, \varepsilon_{i J}$ for all available locations and chooses the location with the highest utility such that individual $i$ chooses location $j$ if and only if $u_{i j}>u_{i j^{\prime}}$ for all $j^{\prime} \neq j$. We can then quantify the probability of this by assuming the $\varepsilon_{i}$ 's are distributed i.i.d. Type I extreme value conditional on $X_{j}$, yielding the following familiar formula for the probability of choosing location $j$, given the location attributes $\left(X_{1}, X_{2}, \ldots, X_{J}, M_{1}, \ldots, M_{J}\right)$ :

$$
\begin{aligned}
q_{i j} & =\operatorname{Pr}\left(u_{i j}>u_{i k} \forall j \neq k\right), \\
& =\int \mathbf{1}\left\{u_{i j}>u_{i k} \forall j \neq k\right\} d G\left(\varepsilon_{i}\right) \\
& =\frac{\exp \left(X_{j} \beta_{i}+\delta_{i} M_{j}\right)}{\sum_{k=1}^{J} \exp \left(X_{k} \beta_{i}+\delta_{i} M_{k}\right)} .
\end{aligned}
$$

One can further assume that $\widetilde{\beta} \equiv\left[\begin{array}{ll}\beta^{\prime} & \delta\end{array}\right]^{\prime}$ is independent of $X$ and $M$ and has population density $f(\widetilde{\beta} \mid \theta)$, where $\theta$ is the vector of parameters describing distribution function $f$. This yields the McFadden and Train (2000) mixed logit model and the population fraction choosing location $j$ can be expressed as:

$$
q_{j}=\int \frac{\exp \left(X_{j} \beta+\delta M_{j}\right)}{\sum_{k=1}^{J} \exp \left(X_{k} \beta+\delta M_{k}\right)} f(\widetilde{\beta} \mid \theta) d \widetilde{\beta}
$$

We follow a growing literature that uses data on hypothetical choices and expectations of future choice decisions to estimate preferences (Blass, Lach, and Manski, 2010; Arcidiacono, Hotz, and Kang, 2012; van der Klaauw, 2012; Arcidiacono et al., 2014; Wiswall and Zafar, 2015, 2018). ${ }^{16}$ To our knowledge, ours is the first study to apply this approach to residential

\footnotetext{
${ }^{16}$ Blass, Lach, and Manski (2010) estimate a model of residential electricity demand. van der Klaauw (2012) estimates a model of occupational choice among teachers. Arcidiacono, Hotz, and Kang (2012); Arcidiacono et al. (2014) and Wiswall and Zafar (2015) estimate preferences for choosing college majors and post-college occupations. Wiswall and Zafar (2018) estimate preferences for job characteristics.
} 
migration decisions. We detail our procedure in the following subsection.

\subsection{Empirical model of hypothetical migration and locational choice}

We now introduce our empirical model for hypothetical choices. Individual $i$ reports a probability of hypothetically choosing option $j$ which can be written as:

$$
q_{i j}=\int 1\left\{X_{j} \beta_{i}+\delta_{i} M_{j}+\varepsilon_{i j}>X_{k} \beta_{i}+\delta_{i} M_{k}+\varepsilon_{i k} \text { for all } k \neq j\right\} d G_{i}\left(\varepsilon_{i}\right)
$$

where $G_{i}\left(\varepsilon_{i}\right)$ is individual $i$ 's belief about the distribution of the $J$ elements comprising the vector $\varepsilon_{i}$. We follow Blass, Lach, and Manski (2010) and Wiswall and Zafar (2018) in interpreting $\varepsilon_{i}$ as resolvable uncertainty, i.e. uncertainty at the time of data collection (about factors unspecified in the scenarios) that the individual knows will be resolved by the time an actual choice would be made. This is consistent with our hypothetical scenarios specifying and exogenously varying a limited set of attributes $X$ but leaving $\varepsilon_{i}$ unspecified. We assume beliefs about the utility from different locations $G_{i}(\cdot)$ in equation 4.5 are i.i.d. Type I extreme value for all individuals. The leads to the standard logit formula for the choice probabilities:

$$
q_{i j}=\frac{\exp \left(X_{j} \beta_{i}+\delta_{i} M_{j}\right)}{\sum_{k=1}^{J} \exp \left(X_{k} \beta_{i}+\delta_{i} M_{k}\right)}
$$

Note that we impose no parametric assumptions on the distribution of the preferences, $\beta_{i}$, in this setup. We can then take the log odds transformation of (4.6) which gives us

$$
\ln \left(\frac{q_{i j}}{q_{i k}}\right)=\left(X_{j}-X_{k}\right) \beta_{i}+\delta_{i}\left(M_{j}-M_{k}\right), \forall j \neq k
$$

where $\beta_{i}$ (or $\delta_{i}$ ) is then interpreted as the marginal change in log odds due to some change in the location attributes, $X($ or $M)$. 


\subsubsection{Measurement error due to rounding}

As noted in the literature and shown in Section 3.3, survey respondents tend to round their subjective probabilities to multiples of $5 \%$ and $10 \%$. To combat against potential bias induced by this rounding, we follow the literature and introduce measurement error into the model and estimate preferences using median regression, which can be estimated by the least absolute deviations (LAD) estimator. This is particularly helpful in dealing with respondents whose true subjective probabilities are close to the corner values of $0 \%$ or $100 \%$, but who round their values to $0 \%$ or $100 \%$ exactly. ${ }^{17}$

We formally introduce this rounding behavior by assuming that our observed probabilities $\tilde{q}_{i j}$ are measured with error such that

$$
\ln \left(\frac{\tilde{q}_{i j}}{\tilde{q}_{i k}}\right)=\left(X_{j}-X_{k}\right) \beta_{i}+\delta_{i}\left(M_{j}-M_{k}\right)+\eta_{i j k}, \quad \forall j \neq k
$$

where $\eta_{i j k}$ captures the (difference in) measurement errors. Assuming that the distribution of $\eta$ (conditional on $X$ ) has a median of 0 , we reach the following expression:

$$
M\left[\ln \left(\frac{\tilde{q}_{i j}}{\tilde{q}_{i k}}\right)\right]=\left(X_{j}-X_{k}\right) \beta_{i}+\delta_{i}\left(M_{j}-M_{k}\right), \forall j \neq k
$$

where $M[\cdot]$ is the median operator. When estimated on a sample of individuals from a given population, the parameter estimates from (4.9) will then represent the median of

the population distribution of $\widetilde{\beta} \equiv\left[\begin{array}{ll}\beta^{\prime} & \delta\end{array}\right]^{\prime}$. When we estimate the parameters on small groups of individuals, it will represent the estimated median of the within-group preference distribution.

\subsection{Identification}

The goal of our model is to recover preferences for location attributes and mobility. Here we discuss how the preference parameters in the model are identified, and the advantages of our hypothetical choice data over previous studies that use observed choices only.

\footnotetext{
${ }^{17}$ For a more complete analysis of rounding in self-reported subjective probabilities, see Giustinelli, Manski, and Molinari (2018).
} 
As discussed in Section 3.3, our key insight is that we experimentally manipulate the attributes of each location, while explicitly stating that all other conditions are identical across locations. Sufficient variation in the attributes across choice scenarios allows us to recover the preference parameters. We consistently estimate the preference parameters so long as the preference shocks $\varepsilon_{i}$ are independent of the attributes. This holds in our context by virtue of our randomized experimental design.

There are a number of advantages to this approach over traditional approaches, as discussed in Section 3.3. First, whereas in revealed-preference data one typically does not observe the choice set the individual considered, here we actually know the pre-specified choice set of the individual. Second, we explicitly manipulate the location of family, whereas the vast majority of observational studies only loosely control for proximity to family by considering if a person lives in their state of birth. ${ }^{18}$ Third, we observe full preference rankings with hypothetical data, because we elicit probabilities of choosing each location, rather than binary choices. That is, our elicited probabilities can be though of as capturing the latent underlying location preferences, as opposed to a simple binary indicator for whether that location has the highest utility. Finally, our hypothetical choice data is free from omitted variable (selection) bias. That is, with observational data, a researcher only sees certain people moving to locations with certain attributes. The observed moves may be a function of other, unobservable location characteristics which in turn are likely to be correlated with the observable attributes. Our approach resolves this bias by experimentally varying the characteristics of each location, while keeping all other attributes identical across locations.

\subsection{Estimation}

We estimate (4.9) by LAD, at multiple levels of aggregation. We first estimate populationlevel preferences, followed by preferences that vary by demographic subgroup. Finally, we estimate preferences at a more refined level, where we group individuals into small groups. These small groups are based on a combination of gender, education level, home ownership status, marital status, age, Census region of residence, and mobile/stuck/rooted status.

\footnotetext{
${ }^{18} \mathrm{An}$ exception to this is the PSID, which explicitly tracks the residence location of respondents and their parents.
} 
Individuals in each group have identical combinations of observable characteristics. We end up with 228 groups, each with 7 individuals on average. ${ }^{19}$ We assume preference homogeneity within groups but allow for unrestricted preference heterogeneity across groups.

We use data on all 8, 16, or 24 scenarios that the individual responds to. There are three choice alternatives in each scenario. Normalizing with respect to alternative 2 , we have two probability ratios and two sets of differenced covariates (the $\left(X_{j}-X_{k}\right)+\left(M_{j}-M_{k}\right)$ in (4.9)) for each scenario. This gives us 16, 32, or 48 choice probabilities per individual. On average, each individual has about 24 choice probabilities.

The vector of covariates is made up of attributes of each location that we experimentally vary. These attributes are: income, housing costs, crime rate, distance, a dummy for if family is living nearby, home size, state and local taxes, a dummy for if local cultural norms are agreeable, and a dummy for having to move (i.e. if choosing location $j$ would result in having to move). ${ }^{20}$ In each equation we also include a constant, as well as a dummy for the third choice alternative. These two indicators will capture any systematic rank-order effects in the probability assigned to each alternative that is unrelated to the scenarios we show the respondents (see Panel (d) of Figure 6). In our small-group analysis, we also allow for an individual fixed effect that is interacted with both the constant and the dummy for the third alternative, to capture individual heterogeneity in alternative-order effects.

We estimate standard errors on the preference parameters by bootstrap sampling of the choice scenarios within group, following Wiswall and Zafar (2018). We use 100 bootstrap replicates.

\section{Results}

We now discuss estimates of the model introduced in the previous section. We first discuss estimates of the preference parameters overall, by demographic subgroup, and heterogeneity by small group. We then discuss how to compute willingness-to-pay (WTP) for each location

\footnotetext{
${ }^{19}$ The smallest 12 groups each contain just two individuals, while the largest 12 groups each contain over 20 individuals.

${ }^{20}$ We allow preferences to be concave in household income, by including in $X$ the logarithm of income, thus allowing for diminishing marginal utility in income and implicitly consumption, following Wiswall and Zafar (2015).
} 
attribute and WTP implied by our preference parameter estimates at the three levels of aggregation of the estimates.

Our main findings are that individuals most strongly value proximity to family and friends and agreeableness of local cultural norms, and that non-pecuniary moving costs are substantial. There is also a great deal of heterogeneity in preferences. Individuals value family proximity at about $\$ 10,000-\$ 20,000$, or roughly $20 \%-50 \%$ of income. Non-pecuniary moving costs also vary substantially. Individuals require between 30\%-200\% of income as compensation for a move. Moreover, about one-third to one-half of the population faces non-pecuniary moving costs approaching infinity.

\subsection{Location Preference Estimates}

We now discuss the preference estimates, which are reported in Tables 5 and 6. Each row of the table corresponds to the median preference estimate for each location characteristic that we vary in our experiment: income, housing costs, crime, distance, family proximity, house size, financial moving costs, taxes, cultural norms, and non-pecuniary moving costs. Each column of each table represents a separate vector of median preference estimates for a different subgroup of our sample. Across the two tables, we compare preference estimates for subgroups defined by gender, age (over or under 50 years old), marital status, education (college graduate or not), children in household, health status, home owner or renter, income level (above or below national median of income), urbanicity (city/suburb/rural), tercile of baseline subjective move probability, tercile of tenure in current home, size of current home (above or below median), median housing costs in ZIP code (above or below national median), and mobile/stuck/rooted status.

While we report a large number of parameter estimates, here we point out the most meaningful ones. Overall, our parameter estimates are consistent with economic theory and findings in the literature. First, there is a large, positive, and significant income elasticity for all subgroups (with one exception), although different groups value income differently. This means that migration decisions are based in part on income maximization. Those who report a baseline probability of moving between $0 \%$ and $2 \%$ are the only group that is not responsive to income. Second, preference heterogeneity manifests in intuitive ways. Those 
living in rural areas, those currently living in smaller homes, and those identifying as "stuck" have the strongest distaste for housing costs. Those currently living in expensive areas have a much weaker distaste for housing costs. House size is not a significant driver of migration for many groups, but is particularly appealing to those with children, renters, those living in smaller houses, and those living in lower-cost locations.

Besides income and housing costs, the two most important factors determining migration are proximity to family and friends and non-pecuniary moving costs. Somewhat surprisingly, there is very little heterogeneity in preferences for family and friends. The notable exception is that those identifying as "mobile" have the lowest marginal utility for living close to family. Non-pecuniary moving costs, on the other hand, are quite different across groups. Most notably, two subgroups - those who identify as "rooted" and those whose baseline subjective move probability is between $0 \%$ and $2 \%$-have moving cost parameter estimates that are an order of magnitude larger than those for the other groups. Our estimates of distaste for moving also closely match with theory or with those documented in the literature: they increase with age (Kennan and Walker, 2011; Bishop, 2012; Ransom, 2019), are larger for homeowners than renters (Oswald, 2018), increase with time spent in current location, increase with house size, and are lowest among those identifying as "mobile."

As mentioned in the estimation section, we also conduct our analysis at the small-group level. We impose preference homogeneity (up to an individual fixed effect to account for individual-specific order effects) within each group. ${ }^{21}$ Across groups, we make no assumptions about the shape of the preference distribution. Distributions of each preference parameter are shown in Figure 7. We estimate our model separately for each of the 228 groups we create. This gives us a vector of 228 median preference parameter estimates. We then plot the resulting distributions for each location characteristic. We restrict our attention to the 181 groups for which income positively influences migration. ${ }^{22}$ Depending on the composition of each group, some groups may not appear in all graphs. ${ }^{23}$

\footnotetext{
${ }^{21}$ Results without individual fixed effects are very similar.

${ }^{22}$ For three groups, the income coefficient was negative. For the remaining 46 groups, the income coefficient was numerically zero. In results not reported, we estimate preferences at the individual level. However, when doing this, estimates become less precise and somewhat more frequently include zero or negative income effects.

${ }^{23}$ For example, if a group contains only individuals from the January wave, then that group has no estimate for the non-pecuniary moving cost, because that characteristic was only varied in the September
} 
The results in Figure 7 point to substantial heterogeneity in preferences. For example, while the modal group has a small positive income elasticity, the average group has an income elasticity an order of magnitude larger, and two orders of magnitude larger for the 90th percentile. Similar patterns hold for other characteristics. In all cases, the distributions are not symmetric, implying that preferences are not distributed normally across our small groups. $^{24}$

Overall, our parameter estimates conform with theory and prior empirical work. An exact interpretation of the parameters themselves is complicated, however, due to the model being non-linear, and due to different groups having different income elasticities. In the next subsection, we discuss how we compute willingness to pay (WTP) for each characteristic. WTP is comparable across groups and allows us to quantify how much money people would trade in exchange for obtaining more of a given attribute.

\subsection{Willingness-to-Pay (WTP) for Location Attributes}

The parameter estimates from the previous subsection are difficult to interpret due to the model being non-linear. In order to be able to compare the importance of different attributes for location choices, we use measures of willingness-to-pay (WTP) that translate the utility difference from changing a given attribute to a difference in household income so that the individual is indifferent between accepting the income difference and choosing the location with that attribute.

Specifically, we construct the WTP for a change of $\Delta$ in a given location attribute $X_{j}$

wave of our survey. Similarly, within survey wave, individuals were randomized into different groups and no one respondent answered all scenarios.

${ }^{24}$ In results not reported, we analyze correlates of each group's median preferences by median-regressing the $\beta_{i}$ for each group on the characteristics of that group. We find that women, at the median, have much stronger preferences than men for income and family, and a much stronger distaste for housing costs, crime, distance, and non-pecuniary moving costs. Groups that are "rooted" tend to have a weaker distaste for crime and stronger distaste for non-pecuniary moving costs. Groups that are homeowners tend to have a weaker taste for home size and a stronger distaste for non-pecuniary moving costs. 
(keeping all the other attributes except for income, $Y$, constant) as follows:

$$
\begin{aligned}
u_{i j}\left(Y, X_{j}, \text { other attributes }\right) & =u_{i j}\left(Y-W T P, X_{j}+\Delta, \text { other attributes }\right) \\
\beta_{y} \ln (Y)+\beta_{j} X_{j} & =\beta_{y} \ln (Y-W T P)+\beta_{j}\left(X_{j}+\Delta\right) \\
-\beta_{j} \Delta & =\beta_{y} \ln \left(\frac{Y-W T P}{Y}\right) \\
W T P & =\underbrace{\left[1-\exp \left(-\frac{\beta_{j}}{\beta_{y}}\right)\right]}_{\text {fraction of income }} Y
\end{aligned}
$$

Depending on the unit of the difference $\Delta$, the WTPs give us a measure that is comparable across different location attributes. Moreover, the WTP measure is flexible enough to accommodate both "good" and "bad" location attributes. If $X_{j}$ is a good attribute $\left(\beta_{j}>0\right)$, a respondent would be willing to forego some income to get more of it, leading to a WTP greater than 0 . On the contrary, if $X_{j}$ is a bad attribute $\left(\beta_{j}<0\right)$, the respondent would need to be compensated to agree to have more of it and this will lead to a WTP less than zero. Note that this interpretation assumes that income is a positive determinant of location choices. $^{25}$

We now present WTP estimates for each of the specifications discussed in the previous subsection. These are reported in two forms: dollar amounts (evaluated at the average income level within the subgroup), and percentage of income (the first term on the right hand side of the last formula in equation (5.1)). We consider the following values of $\Delta$ for each attribute:

- $20 \%$ increase in housing costs

- Doubling of (i.e. $100 \%$ increase in) the crime rate

- 100-mile increase in distance

- 1000-square-foot increase in house size

- $\$ 1,000$ increase in financial moving costs

\footnotetext{
${ }^{25}$ This assumption does not hold for some of our small groups. Thus, we focus our small-group WTP analysis on the ones for which the assumption does hold.
} 
- 5-percentage-point increase in tax rate

- Movement from 0 to 1 for the dummy variables (family proximity, agreeableness of cultural norms, and physically having to move)

We report our estimates of WTP in Tables 7 through 10. Tables 7 and 8 report WTP in dollars (evaluated at the average income level of the subgroup), while Tables 9 and 10 report WTP as a fraction of income. We report WTP in both levels and percentages so as to separate a group's willingness to pay from a group's ability to pay because of higher incomes. For example, those above the median level of income have larger WTP than those below the median, but this difference might be precisely driven by the fact that richer households have higher income.

On the whole, our WTP estimates in large part agree with our discussion of the parameter estimates themselves. Non-pecuniary moving costs command the largest WTP, followed by proximity to family, followed by housing costs and cultural norms. Those living in rural areas and those "stuck" have the strongest distaste for housing costs. Those "rooted" require the largest compensation in order to move. A doubling of the crime rate requires anywhere from $7 \%-14 \%$ of income as compensation, with those "stuck" requiring the most. Distance (conditional on moving) and financial moving costs present the lowest frictions to moving. Both have WTP in the range of $1 \%-2 \%$ of income for an additional 100 miles or $\$ 1,000$ in financial moving costs. Those aged 50 or older have the strongest willingness to pay for lower taxes and more agreeable cultural norms. They also have a distaste for a larger home, perhaps indicating a preference for downsizing. As discussed previously, those living in smaller homes or renting, or "stuck" have the strongest preference for larger house size.

A number of papers in the literature use residence in one's state of birth as a proxy for living near family (Gemici, 2011; Kennan and Walker, 2011; Diamond, 2016; Bartik, 2018; Ransom, 2019, and others). Our approach is able to exactly measure preferences for living near family and friends. We find that they are sizable. The median person in our sample will forego $30 \%$ of his or her income in order to stay close to family. This WTP is larger for those who are over age 50 (40\% of income), and those who are "rooted" or whose baseline move probability is less than $3 \%$ (50\% of income for both). Those who are "mobile" have 
the lowest WTP for family at $17 \%$ of income.

Papers in the literature document substantial non-pecuniary moving costs (Kennan and Walker, 2011; Bishop, 2012; Bartik, 2018; Oswald, 2018; Ransom, 2019). Our results echo these papers even though our empirical setting is slightly different. ${ }^{26}$ For the median person in our sample, we estimate the non-pecuniary cost of moving to be $106 \%$ of income. As with the other papers in the literature, this cost of moving increases with age $(273 \%$ of income for those 50 and older, compared with $57 \%$ of income for those under 50), not graduating college (137\% for non-graduates versus $97 \%$ for graduates), home ownership status (137\% for owners versus $62 \%$ for renters), residential tenure $(200 \%$ for those living $10+$ years in the residence, versus $65 \%$ for those living less than 5 years in the residence), and across baseline subjective move probability and mobile/stuck/rooted status. Most notably, those whose subjective move probability is in the lowest tercile (i.e. in the range $[0 \%, 2 \%]$ ) have infinite moving costs ( $\$ 2$ octillion). Those identifying as "rooted" also face exorbitant moving costs at just under $\$ 14$ million. Our findings are consistent with the analysis of Kennan and Walker (2011), who note that the moving costs of movers are much lower than the moving costs of the average person. This is borne out in our data by noting that those in the highest tercile of subjective move probability, as well as those identifying as "mobile," each have WTP to avoid moving of $33 \%$ of income. This is much lower than the overall median of $106 \%$ and orders of magnitude lower than the people who are "rooted" or who will never move.

We can use our estimates to compute the WTP of a move that would involve leaving behind family, traveling 1,000 miles, moving to a location with less agreeable norms, a 5 percentage point higher local tax rate, and 20\% higher housing costs. For the median person in our sample, such a move would incur a cost of about $187 \%$ of annual income, while for the median "mobile" person, it would be much smaller at $97 \%$ of income. In contrast, the median over-50 person in our sample would be willing to pay $387 \%$ of annual income to avoid such a move. In the most extreme cases, the median "rooted" or non-mover faces an infinite

\footnotetext{
${ }^{26}$ Each of the papers cited estimates a life-cycle dynamic discrete choice model. In our setting, individuals decide whether or not to move with an understanding that they would be required to stay in the destination location for at least 3 years. In this sense, our model is dynamic, but with a much shorter time horizon than the dynamic discrete choice models used in the literature.
} 
cost of moving.

Finally, as with our discussion of the parameter estimates, we show in Figure 8 substantial heterogeneity in WTP at the small-group level. In all cases, preferences are asymmetric. For most characteristics, there is a large portion of the population that has weak tastes (or distastes), while a smaller fraction of the population has strong tastes. On the whole, the results in Figure 8 largely echo those in Figure 7.

\subsection{Discussion}

We now discuss how our findings relate to the literature on declining migration. In order to do so, we assume that our estimated preferences are stable over time - that is, our estimated distribution of preferences (conditional on the observable characteristics in our model) is the same as 30 years ago.

Our estimates are compatible with a number of explanations given for the decline in mobility rates. First, we estimate that non-pecuniary moving costs increase with age. Thus, as the average age of the US population increases, our estimates indicate that migration rates would decline. Similar logic applies to our finding that moving costs are largest among the "rooted." Unfortunately, there is no consistent measure of "rootedness" over time, at least how we measure it. But if more people self-identify as being "rooted" today than in the 1980s, that would result in a decline (Mangum and Coate, 2018).

A second way in which our results conform to existing explanations of the decline in migration is through spillovers. We find that most groups of individuals have a high willingness to pay for living close to family and for living in places that have agreeable social norms and values. The importance of family and norms suggests that they may be an important channel through which a secular decline in mobility can be reinforced. Such a decline in migration reduces the likelihood that family members and/or neighbors with similar values will move away, in addition to directly reducing one's own migration probability. When a sibling is less likely to move away, other siblings are less likely to move, which in turn lowers the mobility rate of the first sibling. Thus, one's own migration likelihood is influenced not only through a direct effect (e.g. declining business dynamism), but also through an indirect effect (Karahan and Rhee, 2017). 
Finally, there are other explanations for the secular decline in migration on which our estimates cannot comment. We do not estimate information frictions (Kaplan and SchulhoferWohl, 2017) and we cannot say if there has been a secular increase in the non-pecuniary costs of moving (Cowen, 2017) or a shift in preferences for location attributes over time.

\section{Conclusion}

In this paper we revisit the literatures on the long-run decline in internal migration in the United States and on the determinants of migration and location choice decisions. While many alternative explanations have been proposed for the long-run decline, none seem to be able to fully explain the broad-based nature of the decline at different levels of geography and across diverse demographic groups.

We contribute to this literature by collecting novel measures of migration attitudes in a nationally representative sample of households. We also conduct a survey experiment on mobility and residential location choice. Our stated-choice experiment elicits choice probabilities from which we recover the distribution of preferences for a variety of location attributes and which yields estimates that are free from selection bias that contaminates estimates based on revealed-preference data.

We find that there is a sizable amount of preference heterogeneity for various attributes. The distribution of heterogeneity tends to be asymmetric. Households in our sample most value income, proximity to family, and agreeableness of local cultural norms, while facing substantial non-pecuniary moving costs.

Our finding of strong preferences for family and local cultural norms suggest that these factors may be acting as migration multipliers. This additional explanation for the long-run decline in migration is in line with the findings of two recent papers (Karahan and Rhee, 2017; Mangum and Coate, 2018).

Finally, while illustrating the immense value of data on subjective probabilities, one potential shortcoming of our approach and the stated-choice framework more generally, is that, while we clearly identify preferences, our experiment does not measure constraints. Because

choices of households will reflect an interaction of preferences and constraints, further analy- 
sis of the policy implications of declining migration will require a more careful consideration of constraints. 


\section{References}

Arcidiacono, Peter, V. Joseph Hotz, and Songman Kang. 2012. "Modeling College Major Choices Using Elicited Measures of Expectations and Counterfactuals." Journal of Econometrics $166(1): 3-16$.

Arcidiacono, Peter, V. Joseph Hotz, Arnaud Maurel, and Teresa Romano. 2014. "Recovering Ex Ante Returns and Preferences for Occupations using Subjective Expectations Data." Working Paper 20626, National Bureau of Economic Research.

Armantier, Olivier, Giorgio Topa, Wilbert van der Klaauw, and Basit Zafar. 2017. "An Overview of the Survey of Consumer Expectations." Economic Policy Review 23 (2):5172 .

Bajari, Patrick and Matthew E. Kahn. 2005. "Estimating Housing Demand With an Application to Explaining Racial Segregation in Cities." Journal of Business \& Economic Statistics 23 (1):20-33.

Bartel, Ann P. 1979. "The Migration Decision: What Role Does Job Mobility Play?" American Economic Review 69 (5):775-786.

Bartik, Alexander W. 2018. "Moving Costs and Worker Adjustment to Changes in Labor Demand: Evidence from Longitudinal Census Data." Working paper, University of Illinois at Urbana-Champaign.

Bayer, Patrick, Fernando Ferreira, and Robert McMillan. 2007. "A Unified Framework for Measuring Preferences for Schools and Neighborhoods." Journal of Political Economy 115 (4):588-638.

Bayer, Patrick, Robert McMillan, Alvin Murphy, and Christopher Timmins. 2016. "A Dynamic Model of Demand for Houses and Neighborhoods." Econometrica 84 (3):893-942.

Bishop, Kelly. 2012. "A Dynamic Model of Location Choice and Hedonic Valuation." Working paper, Washington University in St. Louis.

Blass, Asher A., Saul Lach, and Charles F. Manski. 2010. "Using Elicited Choice Probabilities to Estimate Random Utility Models: Preferences for Electricity Reliability." International Economic Review 51 (2):421-440.

Bleemer, Zachary, Meta Brown, Donghoon Lee, Katherine Strair, and Wilbert van der Klaauw. 2017. "Echoes of Rising Tuition in Students' Borrowing, Educational Attainment, and Homeownership in Post-recession America." Staff Report 820, Federal Reserve Bank of New York. URL https://ssrn. com/abstract=3003050.

Bogart, William T. and Brian A. Cromwell. 2000. "How Much Is a Neighborhood School Worth?" Journal of Urban Economics 47 (2):280-305.

Bricker, Jesse and Brian Bucks. 2016. "Negative Home Equity, Economic Insecurity, and Household Mobility over the Great Recession." Journal of Urban Economics 91:1-12. 
Chan, Sewin. 2001. "Spatial Lock-in: Do Falling House Prices Constrain Residential Mobility?" Journal of Urban Economics 49 (3):567-586.

Chen, Yong and Stuart S. Rosenthal. 2008. "Local Amenities and Life-Cycle Migration: Do People Move for Jobs or Fun?" Journal of Urban Economics 64 (3):519-537.

Chetty, Raj and Nathaniel Hendren. 2018a. "The Impacts of Neighborhoods on Intergenerational Mobility I: Childhood Exposure Effects." The Quarterly Journal of Economics 133 (3):1107-1162.

. 2018b. "The Impacts of Neighborhoods on Intergenerational Mobility
Level Estimates." The Quarterly Journal of Economics 133 (3):1163-1228.

Chetty, Raj, Nathaniel Hendren, and Lawrence F. Katz. 2016. "The Effects of Exposure to Better Neighborhoods on Children: New Evidence from the Moving to Opportunity Experiment." American Economic Review 106 (4):855-902.

Clark, W.A.V. and Jun L. Onaka. 1983. "Life Cycle and Housing Adjustment as Explanations of Residential Mobility." Urban Studies 20 (1):47-57.

Cowen, Tyler. 2017. The Complacent Class: The Self-defeating Quest for the American Dream. New York: St. Martin's Press.

Cullen, Julie Berry and Steven D. Levitt. 1999. "Crime, Urban Flight, and the Consequences for Cities." Review of Economics and Statistics 81 (2):159-169.

Dahl, Gordon B. 2002. "Mobility and the Return to Education: Testing a Roy Model with Multiple Markets." Econometrica 70 (6):2367-2420.

Davis, Steven J., R. Jason Faberman, and John Haltiwanger. 2012. "Labor Market Flows in the Cross Section and over Time." Journal of Monetary Economics 59 (1):1-18.

de Palma, André, Nathalie Picard, and Paul Waddell. 2007. "Discrete Choice Models with Capacity Constraints: An Empirical Analysis of the Housing Market of the Greater Paris Region." Journal of Urban Economics 62 (2):204-230.

Department of the Treasury Office of Economic Policy, Council of Economic Advisers, and Department of Labor. 2015. "Occupational Licensing: A Framework for Policymakers." White house report.

Diamond, Rebecca. 2016. "The Determinants and Welfare Implications of US Workers' Diverging Location Choices by Skill: 1980-2000." American Economic Review 106 (3):479524.

Ferreira, Fernando, Joseph Gyourko, and Joseph Tracy. 2010. "Housing Busts and Household Mobility." Journal of Urban Economics 68 (1):34-45.

Florida, Richard. 2009. Who's Your City?: How the Creative Economy Is Making Where to Live the Most Important Decision of Your Life. Basic Books. 
Foote, Andrew. 2016. "The Effects of Negative House Price Changes on Migration: Evidence across U.S. Housing Downturns." Regional Science and Urban Economics 60:292-299.

Ganong, Peter and Daniel Shoag. 2017. "Why Has Regional Income Convergence in the U.S. Declined?" Journal of Urban Economics 102:76-90.

Gemici, Ahu. 2011. "Family Migration and Labor Market Outcomes." Working paper, New York University.

Giustinelli, Pamela, Charles F. Manski, and Francesca Molinari. 2018. "Tail and Center Rounding of Probabilistic Expectations in the Health and Retirement Study." Working Paper 24559, National Bureau of Economic Research.

Gordan, Ian. 1992. "Modelling Approaches to Migration and the Labour Market." In $M i$ gration Processes and Patterns: Research Progress and Prospects, vol. 1, edited by Anthony Gerard Champion and Anthony Fielding. London: Belhaven.

Habib, Muhammad Ahsanul and Eric J. Miller. 2009. "Reference-Dependent Residential Location Choice Model within a Relocation Context." Transportation Research Record $2133(1): 92-99$.

Hsieh, Chang-Tai and Enrico Moretti. forthcoming. "Housing Constraints and Spatial Misallocation." American Economic Journal: Macroeconomics .

Hyatt, Henry R. and James R. Spletzer. 2013. "The Recent Decline in Employment Dynamics." IZA Journal of Labor Economics 2 (5):1-21.

Johnson, Janna E and Morris M. Kleiner. 2017. "Is Occupational Licensing a Barrier to Interstate Migration?" Working Paper 24107, National Bureau of Economic Research.

Kaplan, Greg and Sam Schulhofer-Wohl. 2012. "Interstate Migration Has Fallen Less Than You Think: Consequences of Hot Deck Imputation in the Current Population Survey." Demography 49 (3):1061-1074.

_. 2017. "Understanding the Long-Run Decline in Interstate Migration." International Economic Review 58 (1):57-94.

Karahan, Fatih and Serena Rhee. 2017. "Population Aging, Migration Spillovers, and the Decline in Interstate Migration." Staff Report 699, Federal Reserve Bank of New York. URL https: //www . newyorkfed.org/medialibrary/media/research/staff_reports/sr699.pdf.

Kennan, John and James R. Walker. 2010. "Wages, Welfare Benefits and Migration." Journal of Econometrics 156 (1):229-238.

2011. "The Effect of Expected Income on Individual Migration Decisions." Econometrica 79 (1):211-251.

Malamud, Ofer and Abigail Wozniak. 2012. "The Impact of College on Migration Evidence from the Vietnam Generation." Journal of Human Resources 47 (4):913-950. 
Mangum, Kyle and Patrick Coate. 2018. "Fast Locations and Slowing Labor Mobility." Research Paper 18-05, Andrew Young School of Policy Studies.

McCauley, Jeremy. 2018. "The Role of Information in Explaining the Lack of Welfare-Induced Migration." Working paper, University College London.

McFadden, Daniel. 1978. "Modelling the Choice of Residential Location." In Spatial Interaction Theory and Planning Models, edited by Anders Karlqvist, Lars Lundqvist, Folke Snickers, and Jörgen W. Weibull. Amsterdam: North Holland, 75-96.

McFadden, Daniel and Kenneth Train. 2000. "Mixed MNL Models for Discrete Response." Journal of Applied Econometrics 15 (5):447-470.

Modestino, Alicia Sasser and Julia Dennett. 2013. "Are American Homeowners Locked into Their Houses? The Impact of Housing Market Conditions on State-to-state Migration." Regional Science and Urban Economics 43 (2):322-337.

Molloy, Raven, Christopher L. Smith, and Abigail Wozniak. 2011. "Internal Migration in the United States." Journal of Economic Perspectives 25 (3):173-196.

Molloy, Raven, Christopher L. Smith, and Abigail K. Wozniak. 2014. "Declining Migration within the U.S.: The Role of the Labor Market." Working Paper 20065, National Bureau of Economic Research.

Nechyba, Thomas J. and Robert P. Strauss. 1998. "Community Choice and Local Public Services: A Discrete Choice Approach." Regional Science and Urban Economics 28 (1):5173 .

Nivalainen, Satu. 2004. "Determinants of family migration: short moves vs. long moves." Journal of Population Economics 17 (1):157-175.

Oswald, Florian. 2018. "The Effect of Homeownership on the Option Value of Regional Migration." Working paper, Sciences Po.

Quigley, John M. 1976. "Housing Demand in the Short Run: An Analysis of Polytomous Choice." In Explorations in Economic Research, vol. 3, edited by National Bureau of Economic Research. Boston: National Bureau of Economic Research, 76-102.

— 1985. "Consumer Choice of Dwelling, Neighborhood and Public Services." Regional Science and Urban Economics 15 (1):41-63.

Ransom, Tyler. 2019. "Labor Market Frictions and Moving Costs of the Employed and Unemployed." Discussion Paper 12139, IZA.

Rapaport, Carol. 1997. "Housing Demand and Community Choice: An Empirical Analysis." Journal of Urban Economics 42 (2):243-260.

Ruggles, Steven, Sarah Flood, Ronald Goeken, Josiah Grover, Erin Meyer, Jose Pacas, and Matthew Sobek. 2019. IPUMS USA: Version 9.0 [dataset]. Minneapolis, MN: IPUMS. 
Schleicher, David. 2017. "Stuck! The Law and Economics of Residential Stagnation." Yale Law Journal 127 (1):1-245.

Tunali, Insan. 2000. "Rationality of Migration." International Economic Review 41 (4):893920.

van de Vyvere, Yves, Harmen Oppewal, and Harry Timmermans. 1998. "The Validity of Hierarchical Information Integration Choice Experiments to Model Residential Preference and Choice." Geographical Analysis 30 (3):254-272.

van der Klaauw, Wilbert. 2012. "On the Use of Expectations Data in Estimating Structural Dynamic Choice Models." Journal of Labor Economics 30 (3):521-554.

Wilson, Riley. 2018a. "Moving to Economic Opportunity: The Migration Response to the Fracking Boom." Working paper, Brigham Young University.

—. 2018b. "Moving to Jobs: The Role of Information in Migration Decisions." Working paper, Brigham Young University.

Wiswall, Matthew and Basit Zafar. 2015. "Determinants of College Major Choice: Identification using an Information Experiment." Review of Economic Studies 82 (2):791-824.

. 2018. "Preference for the Workplace, Investment in Human Capital, and Gender." Quarterly Journal of Economics 133 (1):457-507.

Yagan, Danny. 2014. "Moving to Opportunity? Migratory Insurance over the Great Recession." Working paper, UC Berkeley.

. Forthcoming. "Employment Hysteresis from the Great Recession." Journal of Political Economy . 


\section{Figures and Tables}

Figure 1: Long-run trends in geographic migration in the United States

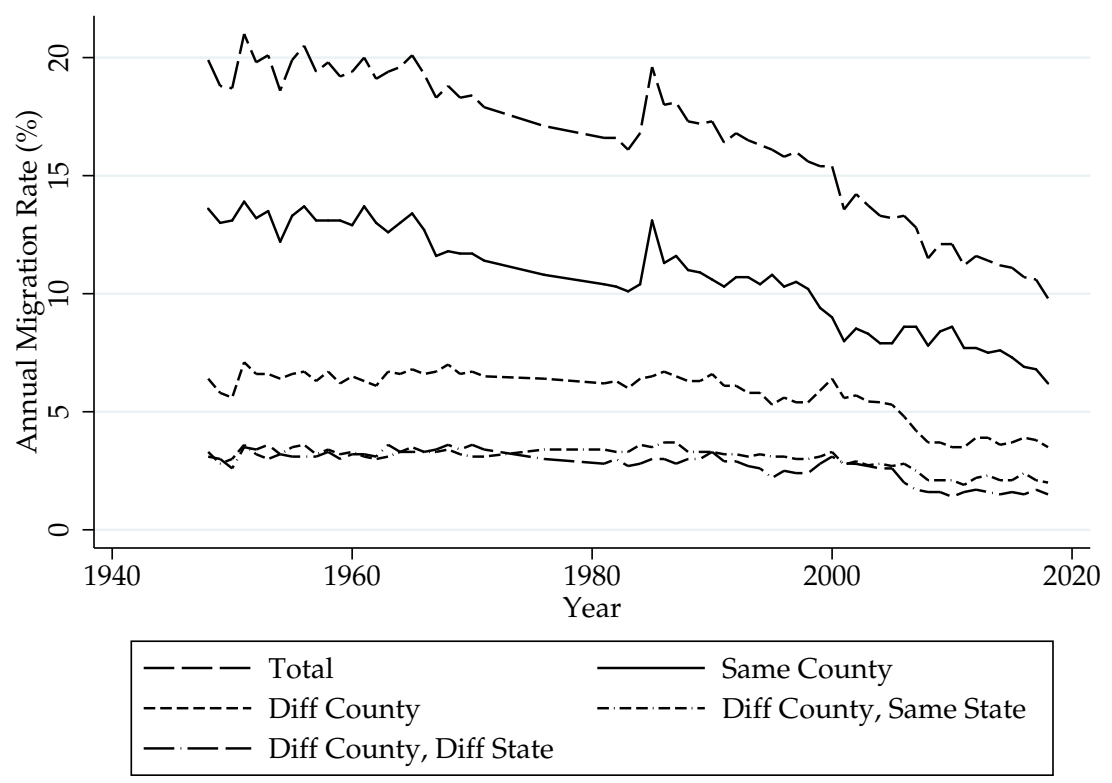

Source: US Census Bureau Current Population Survey (CPS). Mover rate measures share of U.S. residents age 1 and older whose place of residence in March was different from the place of residence one year earlier. https://www. census.gov/data/tables/time-series/demo/geographic-mobility/historic.html 
Figure 2: Reasons for moving, 1999-2018

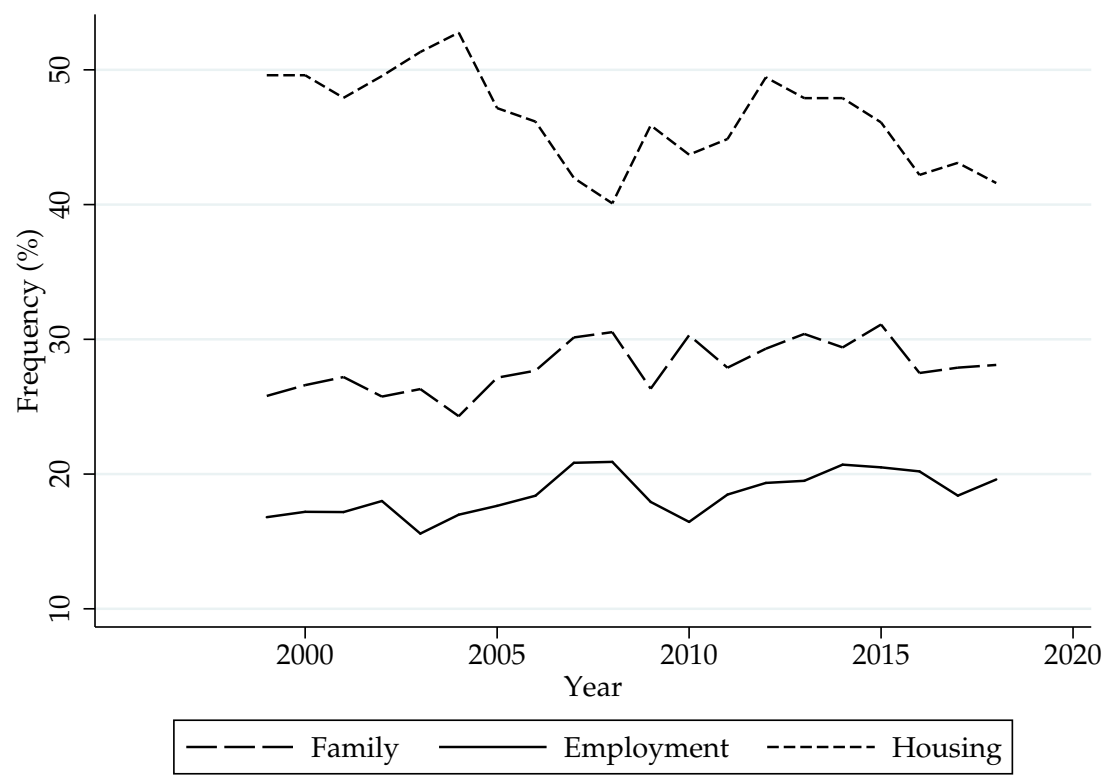

Source: US Census Bureau Current Population Survey (CPS). https://www.census.gov/data/tables/time-series/demo/geographic-mobility/historic.html

Figure 3: Distribution of migration expectations, any distance

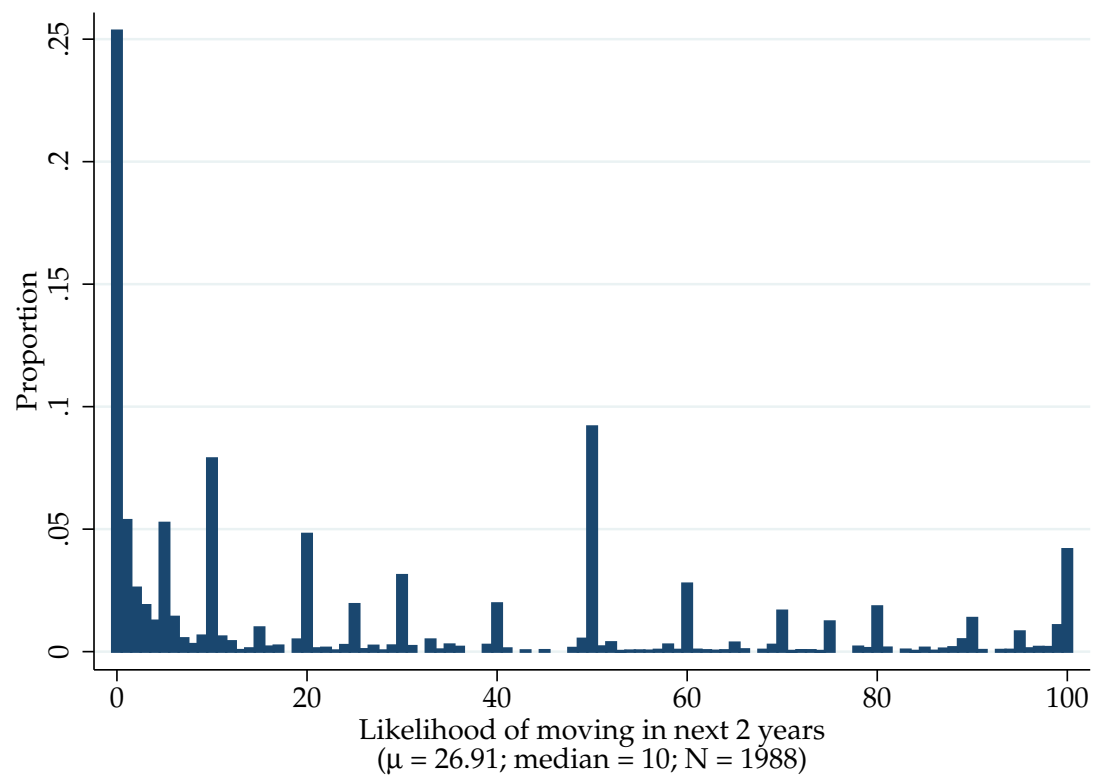

Source: Survey of Consumer Expectations collected in January and September 2018. For details, see Section 3. 
Table 1: Characteristics of SCE sample compared to 2017 ACS

\begin{tabular}{lcc}
\hline & SCE & ACS \\
Variable & Mean & Mean \\
\hline Female & 0.50 & 0.50 \\
White & 0.77 & 0.67 \\
Black & 0.09 & 0.12 \\
Hispanic & 0.09 & 0.13 \\
Asian & 0.03 & 0.05 \\
Age & 50.93 & 52.17 \\
& $(15.33)$ & $(17.17)$ \\
Married & {$[18,96]$} & {$[18,96]$} \\
Lives with children & 0.64 & 0.48 \\
College graduate & 0.42 & 0.39 \\
Owns home & 0.35 & 0.35 \\
Healthy & 0.70 & 0.64 \\
Income (\$1,000) & 0.53 & - \\
& 54.97 & 57.15 \\
Lives near family & $(24.91)$ & $(40.84)$ \\
Pr(move) in next two years & {$[10,246]$} & {$[10,250]$} \\
& 0.77 & - \\
Moved during previous year & 0.27 & - \\
Years lived in current residence & $(0.32)$ & $(-)$ \\
& {$[0,1]$} & {$[-,-]$} \\
Prior to moving to current residence: & 0.15 & 0.13 \\
Lived in same county & 11.91 & - \\
Lived in same state, diff county & $(11.75)$ & $(-)$ \\
Lived in different state & $0,77]$ & {$[-,-]$} \\
Lived in different country & 0.64 & - \\
Lives in city & 0.15 & - \\
Lives in suburb & 0.01 & - \\
Lives in Northeast & 0.22 & 0.25 \\
Lives in Midwest & 0.42 & 0.56 \\
Lives in South & 0.19 & 0.18 \\
Mobile & 0.22 & 0.22 \\
Stuck & 0.37 & 0.38 \\
Rooted & 0.38 & - \\
N & 0.15 & - \\
\hline Sources Strvey Cont & 0.47 & - \\
\hline & 1,988 & $1,243,544$ \\
\hline
\end{tabular}

Sources: Survey of Consumer Expectations collected in January and September 2018, and 2017 American Community Survey (Ruggles et al., 2019).

Notes: Statistics are weighted using the weights provided by each survey. Standard deviation listed below continuous variables in parentheses. Minimum and maximum listed below continuous variables in brackets. For respondents who appear in both SCE waves, we present the characteristics as of January 2018. SCE income is the median income of the Census block group of the household. ACS sample consists of household heads ages 18-96 to match the SCE age ranges. ACS income is individual earnings of the household head and is computed only using household heads earning between $\$ 1 \$ \$ 00-\$ 250,000$. ACS urbanicity is computed only using households whose urbanicity is known. For further details, see Section 3. 
Table 2: Average Characteristics of Mobile, Stuck, and Rooted

\begin{tabular}{|c|c|c|c|c|}
\hline Variable & Mobile & Stuck & Rooted & Total \\
\hline Female & 0.49 & 0.64 & 0.47 & 0.50 \\
\hline White & 0.71 & 0.73 & 0.83 & 0.77 \\
\hline Black & 0.13 & 0.08 & 0.06 & 0.09 \\
\hline Hispanic & 0.10 & 0.12 & 0.07 & 0.09 \\
\hline Asian & 0.03 & 0.03 & 0.02 & 0.03 \\
\hline Age & 47.50 & 46.55 & 55.12 & 50.93 \\
\hline Married & 0.62 & 0.58 & 0.67 & 0.64 \\
\hline Lives with children & 0.42 & 0.50 & 0.39 & 0.42 \\
\hline College graduate & 0.38 & 0.22 & 0.37 & 0.35 \\
\hline Owns home & 0.65 & 0.49 & 0.80 & 0.70 \\
\hline Healthy & 0.60 & 0.33 & 0.53 & 0.53 \\
\hline Income $(\$ 1000)$ & 54.34 & 51.66 & 56.54 & 54.97 \\
\hline Lives near family & 0.70 & 0.82 & 0.80 & 0.77 \\
\hline $\operatorname{Pr}($ move $)$ in next two years & 0.39 & 0.33 & 0.15 & 0.27 \\
\hline Moved during previous year & 0.20 & 0.19 & 0.10 & 0.15 \\
\hline Years lived in current residence & 9.64 & 10.75 & 14.13 & 11.91 \\
\hline \multicolumn{5}{|l|}{ Prior to moving to current residence: } \\
\hline Lived in same county & 0.58 & 0.68 & 0.68 & 0.64 \\
\hline Lived in same state, diff county & 0.21 & 0.20 & 0.18 & 0.20 \\
\hline Lived in different state & 0.19 & 0.09 & 0.13 & 0.15 \\
\hline Lived in different country & 0.01 & 0.00 & 0.00 & 0.01 \\
\hline Lives in city & 0.23 & 0.27 & 0.19 & 0.22 \\
\hline Lives in suburb & 0.42 & 0.42 & 0.43 & 0.42 \\
\hline Lives in Northeast & 0.18 & 0.22 & 0.19 & 0.19 \\
\hline Lives in Midwest & 0.22 & 0.17 & 0.23 & 0.22 \\
\hline Lives in South & 0.39 & 0.37 & 0.37 & 0.37 \\
\hline Sample size & 790 & 243 & 955 & 1,988 \\
\hline
\end{tabular}

Source: Survey of Consumer Expectations collected in January and September 2018. For details, see Section 3 and notes to Table 1. 
Table 3: Most common reasons to not move (\%)

\begin{tabular}{lcccc}
\hline Reason & All & Mobile & Stuck & Rooted \\
\hline Like current home & 73 & 64 & 53 & 87 \\
Like neighborhood and climate & 52 & 38 & 38 & 70 \\
Can't afford to buy home in places I want to move & 50 & 51 & 75 & 39 \\
Closeness to family and friends & 47 & 39 & 39 & 57 \\
Can't afford high cost of moving & 38 & 37 & 64 & 30 \\
Like my current job & 36 & 38 & 23 & 39 \\
Worry about crime rates in other locations & 31 & 31 & 37 & 30 \\
Hard to find job elsewhere & 24 & 25 & 33 & 19 \\
Hard for spouse to find job elsewhere & 22 & 24 & 35 & 17 \\
Good quality of local schools & 22 & 21 & 20 & 23 \\
Very involved in community/church-share values & 21 & 13 & 9 & 33 \\
Locked in low mortgage rate & 21 & 19 & 14 & 24 \\
Difficult to qualify for new mortgage & 19 & 18 & 36 & 14 \\
May lose Medicaid coverage if I move to another state & 13 & 13 & 19 & 11 \\
Am not licensed to work in other states & 8 & 8 & 11 & 7 \\
May lose or receive fewer welfare benefits & 7 & 8 & 14 & 4 \\
\hline Sample size & 1,112 & 448 & 142 & 522 \\
\hline
\end{tabular}

Source: Survey of Consumer Expectations collected in January 2018.

Note: Numbers are percentages of respondents who listed the reason as very important or extremely important. For details, see Section 3. 
Table 4: Most common reasons to move (\%)

\begin{tabular}{lcccc}
\hline Reason & All & Mobile & Stuck & Rooted \\
\hline To be in a more desirable neighborhood or climate & 33 & 43 & 39 & 23 \\
To reduce housing costs & 31 & 35 & 41 & 23 \\
To be closer to family and friends & 29 & 34 & 28 & 25 \\
To be in a safer neighborhood & 28 & 34 & 39 & 20 \\
To upgrade to a larger/better quality home & 27 & 35 & 34 & 17 \\
A new job or job transfer & 18 & 27 & 19 & 10 \\
Better access to amenities (restaurants, theaters, etc.) & 18 & 24 & 19 & 13 \\
To be in better school district/access to better schools & 17 & 22 & 24 & 11 \\
A new job or job transfer of spouse/partner & 16 & 24 & 16 & 10 \\
Don't like my current home & 16 & 20 & 20 & 12 \\
Change in household composition & 16 & 17 & 24 & 13 \\
Cultural values & 15 & 20 & 19 & 10 \\
To reduce commuting time to work/school & 14 & 19 & 13 & 10 \\
To look for a job & 11 & 16 & 15 & 5 \\
May gain Medicaid coverage if I move to another state & 7 & 10 & 10 & 4 \\
May gain or receive more welfare benefits & 5 & 6 & 5 & 3 \\
\hline Sample size & 1,113 & 448 & 143 & 522 \\
\hline
\end{tabular}

Source: Survey of Consumer Expectations collected in January 2018.

Note: Numbers are percentages of respondents who listed the reason as very important or extremely important. For details, see Section 3. 
Figure 4: Sample scenarios from January 2018 wave

Qmv21. Suppose again that you were forced to move today to a location some distance away, and you had to decide which neighborhood to live in. You intend to stay there for at least 3 years. [if own home: Assume that you were able to sell your current primary residence today and pay off your outstanding mortgage (if you have one)].

In each of the 4 scenarios below, you will be shown hypothetical neighborhood characteristics, with each neighborhood characterized by:

- Your household's income prospects

- Distance from your current location

- Family and friends who live in current location moving with you to new location

All neighborhoods are otherwise identical in all other aspects, including costs of housing.

In each scenario, you are given a choice among three neighborhoods and you will be asked for the percent chance (or chances out of 100) of choosing each. The chance of each alternative should be a number between 0 and 100 and the chances given to the three alternatives should add up to 100 .

Scenario 1

$\begin{array}{llll}\text { Neighborhood } & \begin{array}{l}\text { Household } \\ \text { income } \\ \text { compared to } \\ \text { current location }\end{array} & \begin{array}{l}\text { Distance (miles) } \\ \text { from current } \\ \text { location }\end{array} & \begin{array}{l}\text { Family } \\ \text { frien } \\ \text { new }\end{array} \\ \text { A } & \begin{array}{lll}10 \% \text { higher } \\ \text { same }\end{array} & 500 & \text { No } \\ \text { B } & 10 \% \text { lower } & 500 & \text { No } \\ \text { C } & & \text { Yes }\end{array}$

What is the percent chance that you choose to live in each neighborhood? [answers need to add to 100]

A _ percent chance

$\mathrm{B} \_$percent chance

$\mathrm{C} \ldots$ percent chance

Scenario 2

$\begin{array}{llll}\text { Neighborhood } & \begin{array}{l}\text { Household } \\ \text { income } \\ \text { compared to } \\ \text { current location }\end{array} & \begin{array}{l}\text { Distance (miles) } \\ \text { from current } \\ \text { location }\end{array} & \begin{array}{l}\text { Family and } \\ \text { friends move to } \\ \text { new location }\end{array} \\ \text { A } & \begin{array}{l}5 \% \text { lower } \\ \text { same }\end{array} & 500 & \text { Yes } \\ \text { C } & 5 \% \text { lower } & 500 & \text { No } \\ \end{array}$

What is the percent chance that you choose to live in each neighborhood? [answers need to add to 100$]$

A _ percent chance

$\mathrm{B}$ _ percent chance

C _ percent chance 
Figure 5: Sample scenarios from September 2018 wave

Case 3. Suppose again that you [and your household] were offered a few different opportunities to move over the next two years, and you had to decide whether to take any of the offers or to continue living at your current location. The offers to move are contingent on you staying there for at least 3 years. Note that in some scenarios the conditions in your current location (such as household income and whether your family and friends live nearby) may change as well (for example because you or your family and friends move to a different location). [if own; Assume that, if you were to move, you would be able to sell your current primary residence today and pay off your outstanding mortgage (if you have one)]. Neighborhood A represents your current location.

In each of the 4 scenarios below, you will be shown three locations to live in where each is characterized by:

- Distance from your current location

- Family and friends live nearby this location

- Your household's income prospects

Suppose that the locations are otherwise identical in all aspects to your current location, including the cost of housing.

In each scenario, you are given a choice among three neighborhoods and you will be asked for the percent chance (or chances out of 100) of choosing each. The chance of each alternative should be a number between 0 and 100 and the chances given to the three alternatives should add up to 100 .

Scenario 1

$\begin{array}{llll}\text { Neighborhood } & \begin{array}{l}\text { Distance (miles) } \\ \text { from current } \\ \text { location }\end{array} & \begin{array}{l}\text { Family and } \\ \text { friends live in } \\ \text { this location }\end{array} & \begin{array}{l}\text { Household income } \\ \text { compared to current } \\ \text { income }\end{array} \\ \text { A (not move) } & 0 & \text { No } & 10 \% \text { lower } \\ \text { B } & 1000 & \text { Yes } & \text { same } \\ \text { C } & 1000 & \text { No } & 10 \% \text { higher }\end{array}$

What is the percent chance that you choose to live in each neighborhood? [answers need to add to 100$]$

A _ percent chance

$\mathrm{B} \ldots$ percent chance

$\mathrm{C}$

Scenario 2

$\begin{array}{llll}\text { Neighborhood } & \begin{array}{l}\text { Distance (miles) } \\ \text { from current } \\ \text { location }\end{array} & \begin{array}{l}\text { Family and } \\ \text { friends live in } \\ \text { this location }\end{array} & \begin{array}{l}\text { Household income } \\ \text { compared to current } \\ \text { income }\end{array} \\ \text { A (not move) } & 0 & \text { Yes } & 10 \% \text { lower } \\ \text { B } & 500 & \text { Yes } & 50 \% \text { higher } \\ \text { C } & 100 & \text { No } & 20 \% \text { higher }\end{array}$

What is the percent chance that you choose to live in each neighborhood? [answers need to add to 100$]$

A _ percent chance

$\mathrm{B} \_$percent chance

C _ percent chance 
Figure 6: Distribution of subjective choice probabilities, by SCE wave

(a) January, pooled across alternatives

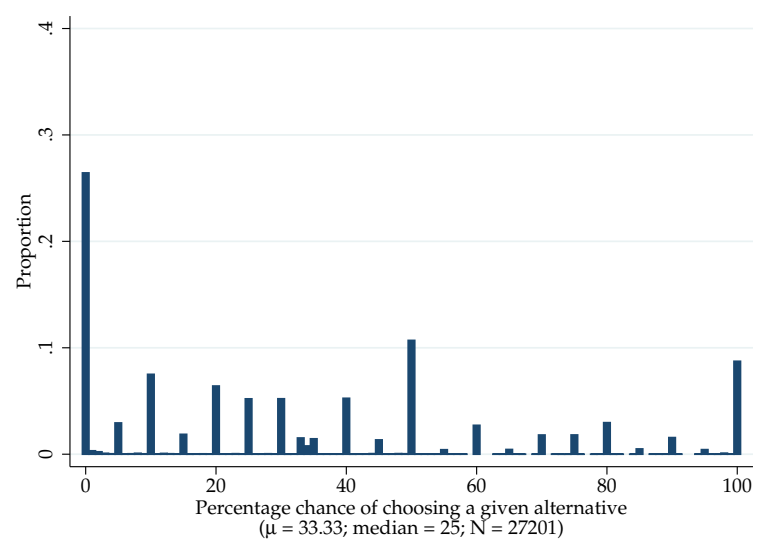

(c) January, average by alternative

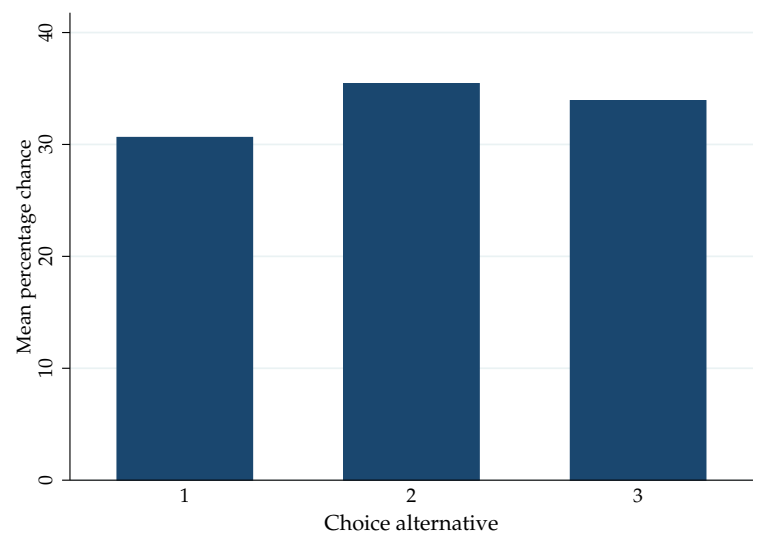

(b) September, pooled across alternatives

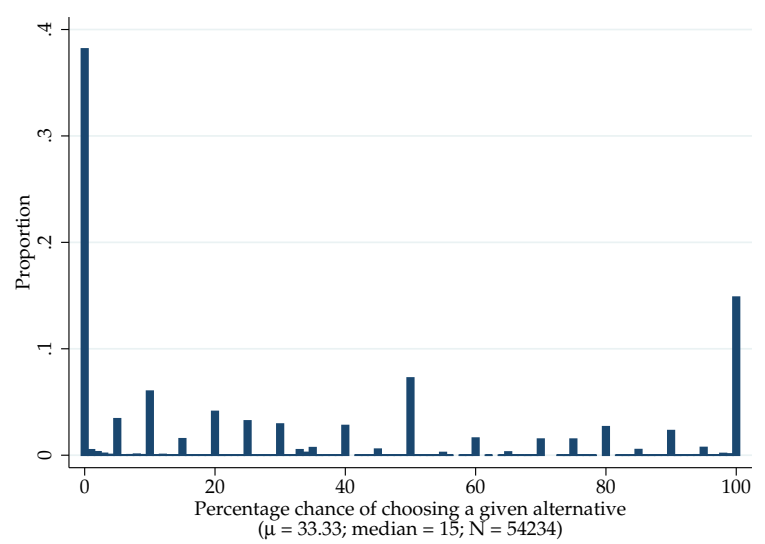

(d) September, average by alternative

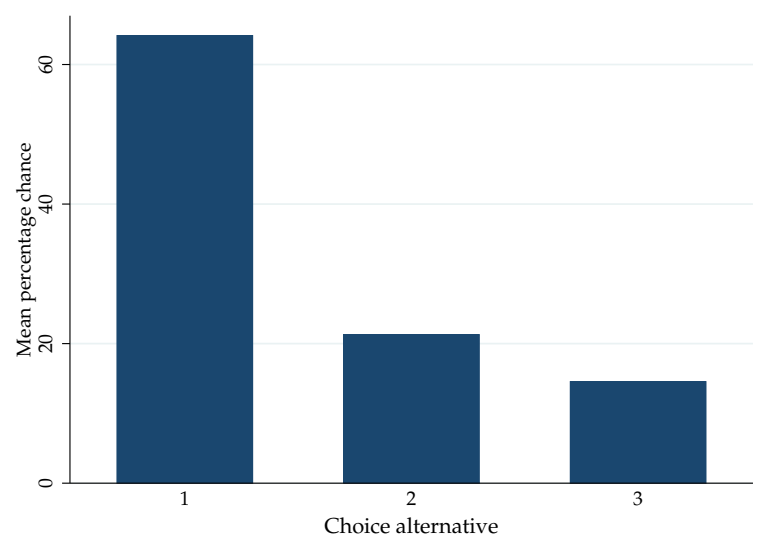

Source: Survey of Consumer Expectations collected in January and September 2018.

Note: Figures are pooled across all choice scenarios. 
Table 5: Choice model estimates

\begin{tabular}{|c|c|c|c|c|c|c|c|c|c|c|c|c|c|c|c|c|c|c|c|c|}
\hline Characteristic & $\begin{array}{l}\text { (1) } \\
\text { all } \\
\end{array}$ & $\begin{array}{c}(2) \\
\text { female }\end{array}$ & $\begin{array}{l}3) \\
\text { ale } \\
\end{array}$ & $\begin{array}{c}(4) \\
\text { young }\end{array}$ & $\begin{array}{l}\text { (5) } \\
\text { old }\end{array}$ & $\begin{array}{c}6) \\
\text { ot married } \\
\end{array}$ & $\begin{array}{c}(7) \\
\text { married }\end{array}$ & $\begin{array}{c}\text { (8) } \\
\text { not coll grad }\end{array}$ & $\begin{array}{c}(9) \\
\text { coll grad } \\
\end{array}$ & $\begin{array}{c}(10) \\
\text { no kids }\end{array}$ & $\begin{array}{l}\text { (11) } \\
\text { kids }\end{array}$ & $\begin{array}{c}\begin{array}{c}(12) \\
\text { healthy }\end{array} \\
\end{array}$ & $\begin{array}{c}\text { (13) } \\
\text { less healthy }\end{array}$ & $\begin{array}{l}(14) \\
\text { renter }\end{array}$ & $\begin{array}{c}(15) \\
\text { owner }\end{array}$ & $\begin{array}{l}(16) \\
\text { poor }\end{array}$ & $\begin{array}{l}(17) \\
\text { rich }\end{array}$ & $\begin{array}{l}(18) \\
\text { city }\end{array}$ & $\begin{array}{c}\quad(19) \\
\text { suburb }\end{array}$ & $\begin{array}{l}(20) \\
\text { rural } \\
\end{array}$ \\
\hline Income & & $\begin{array}{c}4.901^{* * *} \\
(0.350)\end{array}$ & $\begin{array}{c}2.960^{* * *} \\
(0.247)\end{array}$ & $\begin{array}{c}4.856^{* * *} \\
(0.219)\end{array}$ & $\begin{array}{c}2.636^{* * *} \\
(0.254)\end{array}$ & $\begin{array}{c}3.232^{* * *} \\
(0.258)\end{array}$ & $\begin{array}{c}3.965^{* * *} \\
(0.192)\end{array}$ & & & & & & & & & & $\begin{array}{c}3.689 * * * \\
(0.210)\end{array}$ & $\begin{array}{c}3.391^{* * *} \\
(0.317)\end{array}$ & & $\begin{array}{r}3.258^{* * *} \\
(0.319)\end{array}$ \\
\hline Housing costs & & $\begin{array}{c}-5.075^{* * *} \\
(0.931)\end{array}$ & $\begin{array}{c}-2.845 * * * \\
(0.579)\end{array}$ & $\begin{array}{c}-3.716^{* * * *} \\
(0.483)\end{array}$ & $\begin{array}{c}-3.548 * * * \\
(0.736)\end{array}$ & & & & & & $\begin{array}{c}-3.222 * * * \\
(0.511)\end{array}$ & & & & & & & & & $\begin{array}{c}-5.301^{* * * *} \\
(0.953)\end{array}$ \\
\hline Crime & & $\begin{array}{r}-0.561 \\
(0.0\end{array}$ & $\begin{array}{c}-0.394 * * * \\
(0.055)\end{array}$ & $\begin{array}{c}-0.539 * * * \\
(0.035)\end{array}$ & $\begin{array}{c}-0.333^{* * * *} \\
(0.038)\end{array}$ & $\begin{array}{r}-0.37 \\
(0.8\end{array}$ & $\begin{array}{r}-0.46 \\
(0.8\end{array}$ & & & $\begin{array}{c}-0.37 \\
(0.8\end{array}$ & $\begin{array}{c}-0.478 * * * \\
(0.047)\end{array}$ & & & & $\begin{array}{c}-0.396^{* * * *} \\
(0.042)\end{array}$ & & & & & $\begin{array}{c}-0.373^{\text {**** }} \\
(0.050)\end{array}$ \\
\hline Distance & & $\begin{array}{r}-0.072 \\
(0.0)\end{array}$ & $\begin{array}{c}-0.031 * * * \\
(0.006)\end{array}$ & $\begin{array}{c}-0.056^{* * *} \\
(0.005)\end{array}$ & $\begin{array}{c}-0.043^{* * * *} \\
(0.007)\end{array}$ & & & & & & $\begin{array}{c}-0.050^{* * *} \\
(0.005)\end{array}$ & & & & & & & & & $-0.048 * * *$ \\
\hline Family nearby & & & & & & & & & & & & & & & & & & & & $\begin{array}{r}1.273^{* * * *} \\
(0.114)\end{array}$ \\
\hline House square footage & & $\begin{array}{r}0.25 \\
(0.0\end{array}$ & $\begin{array}{r}0.0 \\
(0.0\end{array}$ & $\begin{array}{r}0.33 \\
(0.0\end{array}$ & $\begin{array}{r}-0.12 \\
(0.8\end{array}$ & $\begin{array}{l}0.8 \\
(0.8\end{array}$ & & & & & & & & & & & & & & -0.023 \\
\hline Financial & & $\begin{array}{r}-0.058 \\
(0.00\end{array}$ & $\begin{array}{r}-0.032 \\
(0.0\end{array}$ & $\begin{array}{r}-0.055 \\
(0.00\end{array}$ & & & & & & & & & & & & & & & & \\
\hline Taxes & & & & & & & & & & & & & & & & & & & & \\
\hline Local cultural norms & $\begin{array}{c}0.458^{* * * *} \\
(0.027)\end{array}$ & $\begin{array}{r}0.482^{\prime} \\
(0.04\end{array}$ & $\begin{array}{c}0.502 * * * \\
(0.043)\end{array}$ & $\begin{array}{r}0.456 \\
(0.0\end{array}$ & $\begin{array}{r}0.545 \\
(0.0\end{array}$ & $\begin{array}{c}0.43 \\
(0.8\end{array}$ & 0.46 & & & $\begin{array}{r}0.51 \\
(0.4\end{array}$ & $\begin{array}{c}0.433^{* * * *} \\
(0.034)\end{array}$ & & $\begin{array}{r}0.4 ! \\
(0 .\end{array}$ & $\begin{array}{r}0.4 \mathrm{C} \\
(0 .\end{array}$ & & $\begin{array}{r}0.418 \\
(0.0\end{array}$ & $\begin{array}{c}0.510^{* * * *} \\
(0.049)\end{array}$ & & $\begin{array}{c}0.449 * * * \\
(0.030)\end{array}$ & $\begin{array}{c}0.611^{* * * *} \\
(0.066)\end{array}$ \\
\hline & & & & & & & & & & & & & & & & & & & & \\
\hline & & & & & & & & & & & & & & & & & & & & \\
\hline Constant & $\begin{array}{c}-0.206^{* * *} \\
(0.019)\end{array}$ & $\begin{array}{c}-0.225^{* * *} \\
(0.025)\end{array}$ & $\begin{array}{c}-0.187 * * * \\
(0.032)\end{array}$ & $\begin{array}{c}-0.226^{* * * *} \\
(0.021)\end{array}$ & $\begin{array}{c}-0.263^{* * * *} \\
(0.026)\end{array}$ & $\begin{array}{c}-0.218^{* * * *} \\
(0.044)\end{array}$ & $\begin{array}{c}-0.203^{* * * *} \\
(0.020)\end{array}$ & $\begin{array}{c}-0.152^{* * * *} \\
(0.025)\end{array}$ & $\begin{array}{c}-0.256^{* * * *} \\
(0.028)\end{array}$ & $\begin{array}{c}-0.265^{* * * *} \\
(0.032)\end{array}$ & $\begin{array}{c}-0.202 * * * \\
(0.018)\end{array}$ & $\begin{array}{c}-0.222^{* * * *} \\
(0.026)\end{array}$ & $\begin{array}{c}-0.163^{* * * *} \\
(0.026)\end{array}$ & $\begin{array}{c}-0.183^{* * * *} \\
(0.031)\end{array}$ & $\begin{array}{c}-0.248^{* * * *} \\
(0.031)\end{array}$ & $\begin{array}{c}-0.185^{* * *} \\
(0.023)\end{array}$ & $\begin{array}{c}-0.221 * * * \\
(0.033)\end{array}$ & $\begin{array}{c}-0.187^{* * * *} \\
(0.033)\end{array}$ & $\begin{array}{c}-0.200 * * * \\
(0.025)\end{array}$ & $\begin{array}{r}-0.245^{*} \\
(0.041\end{array}$ \\
\hline & & &, 328 & 22,600 & & & & & & & 19,496 & & & 13,976 & 34,920 & 22,096 & 26,800 & 10,800 & 22,496 & 15,606 \\
\hline
\end{tabular}


Table 6: Choice model estimates (continued)

\begin{tabular}{|c|c|c|c|c|c|c|c|c|c|c|c|c|c|}
\hline Characteristic & $\begin{array}{c}(1) \\
\operatorname{Pr}(\text { move }) \geq 0.33\end{array}$ & $\begin{array}{c}(2) \\
0.03 \leq \operatorname{Pr}(\text { move }) \leq 0.32\end{array}$ & $\begin{array}{c}(3) \\
\operatorname{Pr}(\text { move }) \leq 0.02\end{array}$ & $\begin{array}{c}(4) \\
\text { tenure } \leq 5\end{array}$ & $\begin{array}{c}(5) \\
5<\text { tenure } \leq 10\end{array}$ & $\begin{array}{c}(6) \\
\text { tenure }>10\end{array}$ & $\begin{array}{c}(7) \\
\mathrm{sqft} \leq 1500\end{array}$ & $\begin{array}{c}(8) \\
\text { sqft> } \\
1500\end{array}$ & $\begin{array}{c}(9) \\
\text { price } \\
\text { saft } \leq 150\end{array}$ & $\begin{array}{c}(10) \\
\frac{\text { price }}{\text { sqft }}>150\end{array}$ & $\begin{array}{c}(11) \\
\text { mobile }\end{array}$ & $\begin{array}{l}(12) \\
\text { stuck }\end{array}$ & $\begin{array}{l}(13) \\
\text { rooted }\end{array}$ \\
\hline Income & $\begin{array}{c}4.280^{* * *} \\
(0.284)\end{array}$ & $\begin{array}{c}3.671^{* * *} \\
(0.276)\end{array}$ & $\begin{array}{c}0.264 \\
(0.253)\end{array}$ & $\begin{array}{c}4.756^{* * *} \\
(0.221)\end{array}$ & $\begin{array}{c}3.371^{* * *} \\
(0.443)\end{array}$ & $\begin{array}{c}2.833^{* * *} \\
(0.264)\end{array}$ & $\begin{array}{c}3.621^{* * *} \\
(0.270)\end{array}$ & $\begin{array}{c}3.875 * * * \\
(0.204)\end{array}$ & $\begin{array}{c}3.928^{* * *} \\
(0.270)\end{array}$ & $\begin{array}{c}3.481^{* * *} \\
(0.252)\end{array}$ & $\begin{array}{c}4.312^{* * *} \\
(0.176)\end{array}$ & $\begin{array}{c}3.617^{* * *} \\
(0.367)\end{array}$ & $\begin{array}{c}2.392 * * * \\
(0.232)\end{array}$ \\
\hline Housing costs & $\begin{array}{c}-3.547^{* * * *} \\
(0.479)\end{array}$ & $\begin{array}{c}-4.381^{* * *} \\
(0.644)\end{array}$ & $\begin{array}{l}-0.718 \\
(1.068)\end{array}$ & $\begin{array}{c}-4.894^{* * *} \\
(0.814)\end{array}$ & $\begin{array}{c}-2.936^{* * *} \\
(1.049)\end{array}$ & $\begin{array}{c}-2.299^{* * *} \\
(0.653)\end{array}$ & $\begin{array}{c}-5.168^{* * *} \\
(0.710)\end{array}$ & $\begin{array}{c}-2.930^{* * *} \\
(0.509)\end{array}$ & $\begin{array}{c}-4.291^{* * *} \\
(0.652)\end{array}$ & $\begin{array}{c}-2.907^{* * *} \\
(0.656)\end{array}$ & $\begin{array}{c}-4.785^{* * *} \\
(0.566)\end{array}$ & $\begin{array}{c}-5.634^{* * *} \\
(0.984)\end{array}$ & $\begin{array}{c}-3.543^{* * *} \\
(1.100)\end{array}$ \\
\hline Crime & $\begin{array}{c}-0.513^{* * *} \\
(0.051)\end{array}$ & $\begin{array}{c}-0.622^{* * *} \\
(0.067)\end{array}$ & $\begin{array}{l}-0.026 \\
(0.025)\end{array}$ & $\begin{array}{c}-0.509 * * * \\
(0.041)\end{array}$ & $\begin{array}{c}-0.364^{* * *} \\
(0.060)\end{array}$ & $\begin{array}{c}-0.324^{* * *} \\
(0.047)\end{array}$ & $\begin{array}{c}-0.414^{* * *} \\
(0.038)\end{array}$ & $\begin{array}{c}-0.380^{* * *} \\
(0.044)\end{array}$ & $\begin{array}{c}-0.435^{* * *} \\
(0.040)\end{array}$ & $\begin{array}{c}-0.377^{* * *} \\
(0.045)\end{array}$ & $\begin{array}{c}-0.736^{* * *} \\
(0.065)\end{array}$ & $\begin{array}{c}-0.668^{* * *} \\
(0.117)\end{array}$ & $\begin{array}{c}-0.234^{* * *} \\
(0.023)\end{array}$ \\
\hline Distance & $\begin{array}{c}-0.047^{* * *} \\
(0.006)\end{array}$ & $\begin{array}{c}-0.054^{* * *} \\
(0.008)\end{array}$ & $\begin{array}{l}-0.003 \\
(0.003)\end{array}$ & $\begin{array}{c}-0.056^{* * *} \\
(0.005)\end{array}$ & $\begin{array}{c}-0.046 * * * \\
(0.009)\end{array}$ & $\begin{array}{c}-0.042^{* * *} \\
(0.005)\end{array}$ & $\begin{array}{c}-0.053^{* * *} \\
(0.005)\end{array}$ & $\begin{array}{c}-0.044^{* * *} \\
(0.004)\end{array}$ & $\begin{array}{c}-0.051^{* * *} \\
(0.006)\end{array}$ & $\begin{array}{c}-0.044^{* * *} \\
(0.006)\end{array}$ & $\begin{array}{c}-0.036^{* * *} \\
(0.005)\end{array}$ & $\begin{array}{c}-0.041^{* * *} \\
(0.008)\end{array}$ & $\begin{array}{c}-0.029^{* * *} \\
(0.004)\end{array}$ \\
\hline Family nearby & $\begin{array}{c}1.132^{* * *} \\
(0.070)\end{array}$ & $\begin{array}{c}1.372^{* * *} \\
(0.085)\end{array}$ & $\begin{array}{c}0.182 \\
(0.174)\end{array}$ & $\begin{array}{c}1.359^{* * *} \\
(0.093)\end{array}$ & $\begin{array}{c}1.440^{* * * *} \\
(0.183)\end{array}$ & $\begin{array}{c}1.214^{* * *} \\
(0.119)\end{array}$ & $\begin{array}{c}1.184^{* * *} \\
(0.080)\end{array}$ & $\begin{array}{c}1.533^{* * *} \\
(0.092)\end{array}$ & $\begin{array}{c}1.516^{* * *} \\
(0.096)\end{array}$ & $\begin{array}{c}1.248^{* * *} \\
(0.101)\end{array}$ & $\begin{array}{c}0.824^{* * *} \\
(0.069)\end{array}$ & $\begin{array}{c}1.150^{* * *} \\
(0.145)\end{array}$ & $\begin{array}{c}1.644^{* * * *} \\
(0.161)\end{array}$ \\
\hline House square footage & $\begin{array}{l}0.134^{*} \\
(0.079)\end{array}$ & $\begin{array}{l}-0.045 \\
(0.049)\end{array}$ & $\begin{array}{c}0.004 \\
(0.007)\end{array}$ & $\begin{array}{c}0.340^{* * * *} \\
(0.050)\end{array}$ & $\begin{array}{c}0.068 \\
(0.092)\end{array}$ & $\begin{array}{l}-0.093 \\
(0.075)\end{array}$ & $\begin{array}{c}0.249^{* * *} \\
(0.047)\end{array}$ & $\begin{array}{l}-0.028 \\
(0.063)\end{array}$ & $\begin{array}{c}0.184^{* * *} \\
(0.057)\end{array}$ & $\begin{array}{c}0.087 \\
(0.073)\end{array}$ & $\begin{array}{c}0.036 \\
(0.062)\end{array}$ & $\begin{array}{l}0.247^{*} \\
(0.140)\end{array}$ & $\begin{array}{l}0.132^{* *} \\
(0.065)\end{array}$ \\
\hline Financial moving costs & $\begin{array}{c}-0.048^{* * *} \\
(0.003)\end{array}$ & $\begin{array}{c}-0.044^{* * *} \\
(0.003)\end{array}$ & $\begin{array}{l}-0.002 \\
(0.002)\end{array}$ & $\begin{array}{c}-0.054^{* * *} \\
(0.003)\end{array}$ & $\begin{array}{c}-0.039 * * * \\
(0.005)\end{array}$ & $\begin{array}{c}-0.034^{* * *} \\
(0.003)\end{array}$ & $\begin{array}{c}-0.043^{* * *} \\
(0.003)\end{array}$ & $\begin{array}{c}-0.042^{* * *} \\
(0.003)\end{array}$ & $\begin{array}{c}-0.046^{* * *} \\
(0.003)\end{array}$ & $\begin{array}{c}-0.040^{* * *} \\
(0.003)\end{array}$ & $\begin{array}{c}-0.047^{* * *} \\
(0.003)\end{array}$ & $\begin{array}{c}-0.040^{* * *} \\
(0.004)\end{array}$ & $\begin{array}{c}-0.026^{* * *} \\
(0.003)\end{array}$ \\
\hline Taxes & $\begin{array}{c}-0.045^{* * *} \\
(0.005)\end{array}$ & $\begin{array}{c}-0.054^{* * *} \\
(0.010)\end{array}$ & $\begin{array}{l}-0.004 \\
(0.003)\end{array}$ & $\begin{array}{c}-0.058^{* * *} \\
(0.007)\end{array}$ & $\begin{array}{c}-0.031^{* * *} \\
(0.006)\end{array}$ & $\begin{array}{c}-0.044^{* * *} \\
(0.011)\end{array}$ & $\begin{array}{c}-0.047^{* * *} \\
(0.007)\end{array}$ & $\begin{array}{c}-0.050^{* * *} \\
(0.009)\end{array}$ & $\begin{array}{c}-0.052^{* * *} \\
(0.009)\end{array}$ & $\begin{array}{c}-0.042^{* * *} \\
(0.008)\end{array}$ & $\begin{array}{c}-0.054^{* * *} \\
(0.009)\end{array}$ & $\begin{array}{c}-0.043^{* * *} \\
(0.013)\end{array}$ & $\begin{array}{c}-0.034^{* * *} \\
(0.009)\end{array}$ \\
\hline Local cultural norms & $\begin{array}{c}0.447^{* * *} \\
(0.031)\end{array}$ & $\begin{array}{c}0.554^{* * *} \\
(0.048)\end{array}$ & $\begin{array}{c}0.265^{* * *} \\
(0.085)\end{array}$ & $\begin{array}{c}0.519^{* * *} \\
(0.038)\end{array}$ & $\begin{array}{c}0.353^{* * *} \\
(0.048)\end{array}$ & $\begin{array}{c}0.495^{* * *} \\
(0.052)\end{array}$ & $\begin{array}{c}0.411^{* * *} \\
(0.030)\end{array}$ & $\begin{array}{c}0.517^{* * *} \\
(0.050)\end{array}$ & $\begin{array}{c}0.441^{* * *} \\
(0.041)\end{array}$ & $\begin{array}{c}0.439^{* * *} \\
(0.039)\end{array}$ & $\begin{array}{c}0.516^{* * *} \\
(0.042)\end{array}$ & $\begin{array}{c}0.441^{* * *} \\
(0.085)\end{array}$ & $\begin{array}{c}0.398^{* * *} \\
(0.050)\end{array}$ \\
\hline Nonpecuniary moving costs & $\begin{array}{c}-1.295^{* * *} \\
(0.090)\end{array}$ & $\begin{array}{c}-2.497^{* * *} \\
(0.078)\end{array}$ & $\begin{array}{c}-13.830^{* * *} \\
(0.071)\end{array}$ & $\begin{array}{c}-2.374^{* * *} \\
(0.080)\end{array}$ & $\begin{array}{c}-2.664^{* * *} \\
(0.156)\end{array}$ & $\begin{array}{c}-3.110^{* * *} \\
(0.092)\end{array}$ & $\begin{array}{c}-2.310^{* * *} \\
(0.081)\end{array}$ & $\begin{array}{c}-3.154^{* * *} \\
(0.085)\end{array}$ & $\begin{array}{c}-2.839^{* * *} \\
(0.109)\end{array}$ & $\begin{array}{c}-2.625^{* * *} \\
(0.103)\end{array}$ & $\begin{array}{c}-1.187^{* * *} \\
(0.075)\end{array}$ & $\begin{array}{c}-2.276^{* * *} \\
(0.141)\end{array}$ & $\begin{array}{c}-13.465^{* * * *} \\
(0.097)\end{array}$ \\
\hline Alternative 3 dummy & $\begin{array}{c}0.219^{* * *} \\
(0.025)\end{array}$ & $\begin{array}{c}0.292^{* * *} \\
(0.032)\end{array}$ & $\begin{array}{c}0.028 \\
(0.074)\end{array}$ & $\begin{array}{c}0.217^{* * *} \\
(0.027)\end{array}$ & $\begin{array}{c}0.219^{* * *} \\
(0.044)\end{array}$ & $\begin{array}{c}0.255^{* * *} \\
(0.037)\end{array}$ & $\begin{array}{c}0.185^{* * *} \\
(0.028)\end{array}$ & $\begin{array}{c}0.295^{* * *} \\
(0.035)\end{array}$ & $\begin{array}{c}0.179^{* * *} \\
(0.021)\end{array}$ & $\begin{array}{c}0.197^{* * *} \\
(0.041)\end{array}$ & $\begin{array}{c}0.236^{* * *} \\
(0.022)\end{array}$ & $\begin{array}{c}0.226^{* * *} \\
(0.080)\end{array}$ & $\begin{array}{c}0.213^{* * *} \\
(0.060)\end{array}$ \\
\hline Constant & $\begin{array}{c}-0.220^{* * *} \\
(0.025)\end{array}$ & $\begin{array}{c}-0.285^{* * *} \\
(0.026)\end{array}$ & $\begin{array}{l}-0.024 \\
(0.073)\end{array}$ & $\begin{array}{c}-0.227^{* * * *} \\
(0.021)\end{array}$ & $\begin{array}{c}-0.199 * * * \\
(0.037)\end{array}$ & $\begin{array}{c}-0.249^{* * * *} \\
(0.039)\end{array}$ & $\begin{array}{c}-0.178^{* * * *} \\
(0.028)\end{array}$ & $\begin{array}{c}-0.265^{* * *} \\
(0.035)\end{array}$ & $\begin{array}{c}-0.182^{* * *} \\
(0.020)\end{array}$ & $\begin{array}{c}-0.197^{* * *} \\
(0.038)\end{array}$ & $\begin{array}{c}-0.267^{* * * *} \\
(0.021)\end{array}$ & $\begin{array}{c}-0.224^{* * *} \\
(0.075)\end{array}$ & $\begin{array}{c}-0.183^{* * *} \\
(0.059)\end{array}$ \\
\hline Observations & 16,320 & 16,736 & 15,840 & 19,824 & 8,712 & 20,360 & 24,872 & 23,520 & 22,688 & 18,216 & 18,760 & 6,000 & 24,104 \\
\hline
\end{tabular}

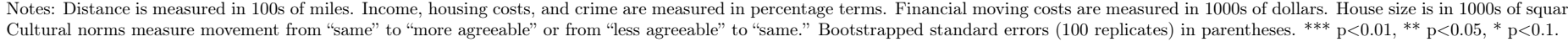


Figure 7: Distribution of median $\beta_{i}$ by small group
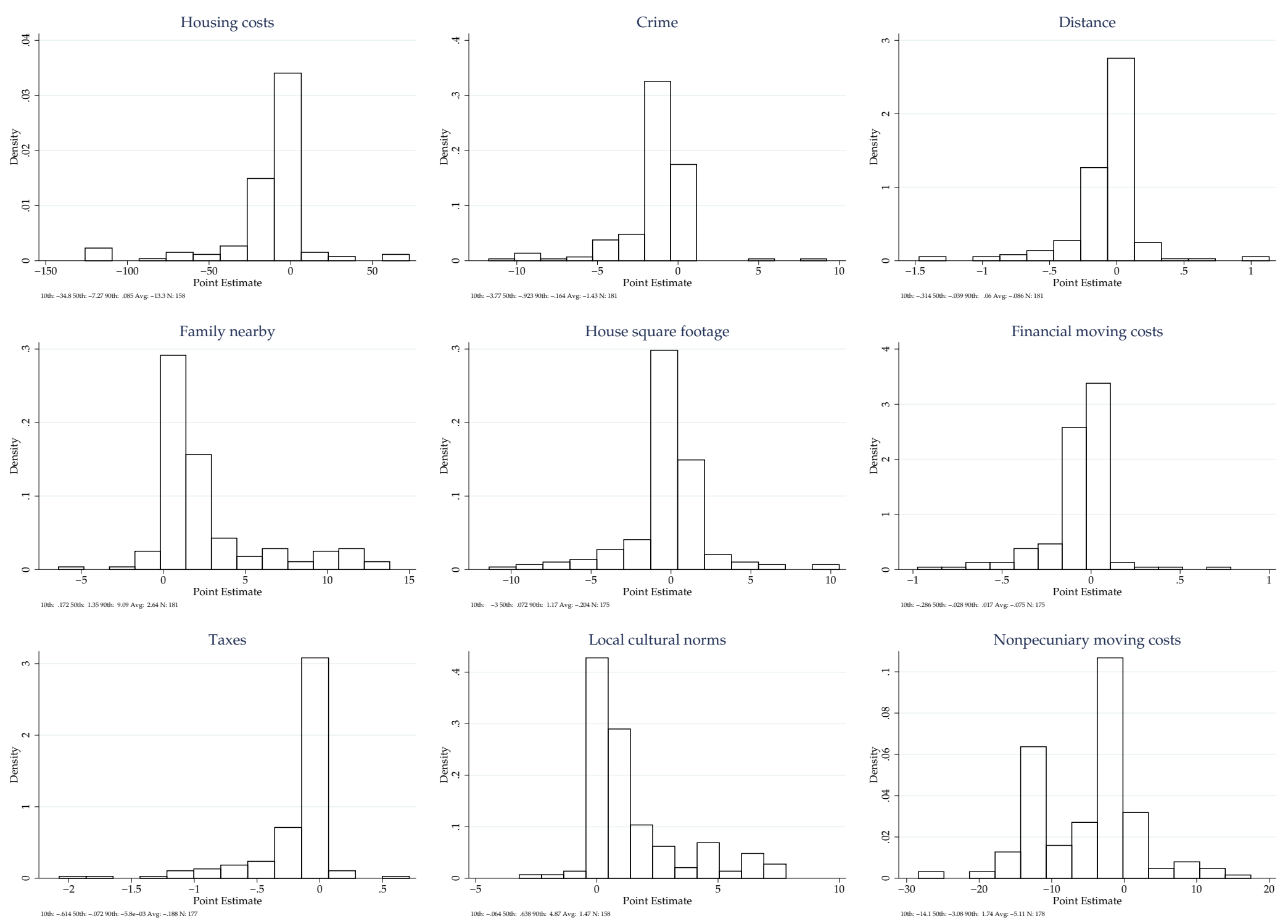
Table 7: Neighborhood choice WTP estimates (dollars

\begin{tabular}{|c|c|c|c|c|c|c|c|c|c|c|c|c|c|c|c|c|c|c|c|c|}
\hline Characteristic & $\begin{array}{l}(1) \\
\text { all }\end{array}$ & $\begin{array}{c}(2) \\
\text { female }\end{array}$ & $\begin{array}{c}(3) \\
\text { male }\end{array}$ & $\begin{array}{c}(4) \\
\text { young }\end{array}$ & $\begin{array}{l}\text { (5) } \\
\text { old }\end{array}$ & $\begin{array}{c}(6) \\
\text { not married }\end{array}$ & $\begin{array}{l}(7) \\
\text { married }\end{array}$ & $\begin{array}{c}\text { (8) } \\
\text { not coll grad } \\
\end{array}$ & $\begin{array}{c}(9) \\
\text { coll grad } \\
\end{array}$ & $\begin{array}{c}(10) \\
\text { no kids }\end{array}$ & $\begin{array}{l}(11) \\
\text { kids }\end{array}$ & $\begin{array}{c}\begin{array}{c}(12) \\
\text { healthy }\end{array} \\
\end{array}$ & $\begin{array}{c}(13) \\
\text { less healthy }\end{array}$ & $\begin{array}{l}(14) \\
\text { renter }\end{array}$ & $\begin{array}{l}(15) \\
\text { owner }\end{array}$ & $\begin{array}{l}(16) \\
\text { poor }\end{array}$ & $\begin{array}{l}\text { (17) } \\
\text { rich }\end{array}$ & $\begin{array}{l}(18) \\
\text { city }\end{array}$ & $\begin{array}{c}(19) \\
\text { suburb }\end{array}$ & $\begin{array}{l}(20) \\
\text { rural } \\
\end{array}$ \\
\hline Housing costs & $\begin{array}{c}-9,7777^{* * *} \\
(1,281)\end{array}$ & $\begin{array}{c}-9,550^{* * *} \\
(1.977)\end{array}$ & $\begin{array}{c}-9,852 * * * \\
(2,181)\end{array}$ & $\begin{array}{c}-7,221 * * * \\
(995)\end{array}$ & $\begin{array}{c}-13,629 * * * \\
(3.459)\end{array}$ & $\begin{array}{c}-12,406 * * * \\
(2.973)\end{array}$ & $\begin{array}{c}-8,5555^{* * *} \\
(1065)\end{array}$ & $\begin{array}{l}-8,093^{* * *} \\
(2651)\end{array}$ & $\begin{array}{c}-12,482 * * * \\
(1,694)\end{array}$ & $\begin{array}{c}-12,039 * * * \\
(2,404)\end{array}$ & $\begin{array}{c}-7,631 * * * \\
(1,317)\end{array}$ & $\begin{array}{c}-11,578 * * * \\
(1,980)\end{array}$ & $\begin{array}{l}-8,023^{* * * *} \\
(1834)\end{array}$ & $\begin{array}{c}-10,800 * * * \\
(2.543)\end{array}$ & & $\begin{array}{c}-9,310^{* * *} \\
(1,478)\end{array}$ & $\begin{array}{c}-10,823^{* * *} \\
(2090)\end{array}$ & & $\begin{array}{l}-9,789^{* * * *} \\
(1,477)\end{array}$ & \\
\hline Crime & $\begin{array}{c}-3,818^{* * *} \\
(189)\end{array}$ & $\begin{array}{c}-3,7933^{* * *} \\
(104)\end{array}$ & $\begin{array}{l}-4,975 * * * \\
(697)\end{array}$ & $\begin{array}{c}-3,859^{* * *} \\
(242)\end{array}$ & $\begin{array}{c}-4,486^{* * *} \\
(312)\end{array}$ & $\begin{array}{c}-3,578^{* * *} \\
(128)\end{array}$ & $\begin{array}{l}-4,435 * * * \\
(324)\end{array}$ & $\begin{array}{c}-3,7377^{* * *} \\
(150)\end{array}$ & $\begin{array}{c}-4,666^{* * *} \\
(506)\end{array}$ & $\begin{array}{l}-3,845 * * * \\
(270)\end{array}$ & $\begin{array}{c}-4,175 * * * \\
(357)\end{array}$ & $\begin{array}{c}-3,903^{* * *} \\
(282)\end{array}$ & $\begin{array}{c}-3,6733^{* * *} \\
(247)\end{array}$ & $\begin{array}{c}-3,516^{* * *} \\
(193)\end{array}$ & $\begin{array}{r}-4,12 \\
(48\end{array}$ & $\begin{array}{l}-3,0811^{* * *} \\
(98)\end{array}$ & $\begin{array}{c}-5,6555^{* * *} \\
(704)\end{array}$ & $\begin{array}{r}-3,73 \\
(47\end{array}$ & $\begin{array}{c}-4,816^{* * *} \\
(374)\end{array}$ & $\begin{array}{c}-3,565 * 3 * * * \\
(355)\end{array}$ \\
\hline Distance & $\begin{array}{l}-619^{* * *} \\
(62)\end{array}$ & $\begin{array}{l}-681 * * * \\
(34)\end{array}$ & $\begin{array}{l}-545^{* * *} \\
(86)\end{array}$ & $\begin{array}{l}-557 * * * \\
(37)\end{array}$ & $\begin{array}{c}-814^{* * * *} \\
(103)\end{array}$ & $\begin{array}{l}-642^{* * * *} \\
(34)\end{array}$ & $\begin{array}{l}-576^{* * * *} \\
(41)\end{array}$ & $\begin{array}{l}-671 * * * \\
(35)\end{array}$ & $-681^{* * *}$ & $\begin{array}{l}-690^{* * * *} \\
(63)\end{array}$ & $\begin{array}{l}-612^{* * * *} \\
(43)\end{array}$ & $\begin{array}{l}-598 * * * \\
(46)\end{array}$ & $-659^{* * *}$ & $-631 * * *$ & $\begin{array}{l}-684^{* * *} \\
(72)\end{array}$ & $\begin{array}{l}-553 * * * \\
(38)\end{array}$ & $\begin{array}{l}-745^{* * *} \\
(63)\end{array}$ & $\begin{array}{l}-620^{* * *} \\
(65)\end{array}$ & $-710^{* * * *}$ & $\begin{array}{c}-640 * * * \\
(56)\end{array}$ \\
\hline Family nearby & $\begin{array}{c}14,055 * * * \\
(598)\end{array}$ & $\begin{array}{c}14,848 * * * \\
(908)\end{array}$ & $\begin{array}{c}14,584 * * * \\
(1,011)\end{array}$ & $\begin{array}{c}11,592^{* * *} \\
(609)\end{array}$ & $\begin{array}{c}19,548^{* * *} \\
(1,433)\end{array}$ & $\begin{array}{c}12,284^{* * *} \\
(1,012)\end{array}$ & $\begin{array}{c}15,832 * * * \\
(733)\end{array}$ & $\begin{array}{c}15,669^{* * *} \\
(1,320)\end{array}$ & $\begin{array}{c}16,829 * * * \\
(916)\end{array}$ & $\begin{array}{c}14,792^{* * *} \\
(948)\end{array}$ & $\begin{array}{c}14,483^{* * *} \\
(974)\end{array}$ & $\begin{array}{c}15,044^{* * * *} \\
(833)\end{array}$ & $\begin{array}{c}13,594^{* * *} \\
(1,011)\end{array}$ & $\begin{array}{c}10,994^{* * *} \\
(719)\end{array}$ & $\begin{array}{c}16,661^{* * * *} \\
(921)\end{array}$ & $\begin{array}{c}10,289 * * * \\
(673)\end{array}$ & $\begin{array}{c}21,010^{* * *} \\
(1,053)\end{array}$ & $\begin{array}{c}12,329 * * * \\
(1,200)\end{array}$ & $\begin{array}{c}17,259 * * * \\
(1,018)\end{array}$ & $\begin{array}{c}13,971^{* * * *} \\
(1,181)\end{array}$ \\
\hline House square footage & $\begin{array}{c}1,432 * * * \\
(538)\end{array}$ & $\begin{array}{c}2,298^{* * *} \\
(480)\end{array}$ & $\begin{array}{c}295 \\
(1,075)\end{array}$ & $\begin{array}{l}3,230 * * * \\
(397)\end{array}$ & $\begin{array}{c}-2,3222^{* * *} \\
(625)\end{array}$ & $\begin{array}{l}368 \\
(1,213)\end{array}$ & $\begin{array}{l}1,588 * * \\
(630)\end{array}$ & $\begin{array}{l}2,216 * * * * \\
(627)\end{array}$ & $\begin{array}{l}512 \\
(900)\end{array}$ & $\begin{array}{l}-921 \\
(913)\end{array}$ & $\begin{array}{l}3,538 * * * \\
(483)\end{array}$ & $\begin{array}{l}1,275 \\
(843)\end{array}$ & $\begin{array}{l}1,981 * * * \\
(683)\end{array}$ & $\begin{array}{l}3,146 * * * \\
(1,154)\end{array}$ & $\begin{array}{c}69 \\
(929)\end{array}$ & $\begin{array}{l}1,896 * * * \\
(501)\end{array}$ & $\begin{array}{r}85 \\
(1,3\end{array}$ & $\begin{array}{l}1,3 \\
(88\end{array}$ & $\begin{array}{c}3,3770 * * \\
(802)\end{array}$ & $\begin{array}{c}-304 \\
(1,165)\end{array}$ \\
\hline Financial moving costs & $\begin{array}{c}-565^{* * *} \\
(13)\end{array}$ & $\begin{array}{c}-552^{* * * *} \\
(8)\end{array}$ & $\begin{array}{c}-558^{* * * *} \\
(73)\end{array}$ & $\begin{array}{c}-545^{* * *} \\
(16)\end{array}$ & $\begin{array}{c}-629 * * * \\
(27)\end{array}$ & $\begin{array}{c}-522^{* * * *} \\
(11)\end{array}$ & $\begin{array}{c}-577 * * * \\
(15)\end{array}$ & $\begin{array}{r}-544 \\
(12\end{array}$ & $\begin{array}{c}-668 * * * \\
(15)\end{array}$ & $\begin{array}{c}-559^{* * *} \\
(16)\end{array}$ & $\begin{array}{l}-589 * * * \\
(12)\end{array}$ & $\begin{array}{l}-591 * * * \\
(18)\end{array}$ & $\begin{array}{l}-534^{* * *} \\
(11)\end{array}$ & -511 & -608 & -448 & & $\begin{array}{r}-502 \\
(1\end{array}$ & $\begin{array}{c}-685^{* * *} \\
(19)\end{array}$ & $\begin{array}{c}-519^{* * *} \\
(15)\end{array}$ \\
\hline Taxes & $\begin{array}{c}-3,319^{* * *} \\
(458)\end{array}$ & $\begin{array}{c}-2,473^{* * *} \\
(428)\end{array}$ & $\begin{array}{c}-3,629^{* * *} \\
(759)\end{array}$ & $\begin{array}{c}-2,413^{* * *} \\
(194)\end{array}$ & $\begin{array}{c}-4,920^{* * *} \\
(1,179)\end{array}$ & $\begin{array}{c}-2,956^{* * *} \\
(717)\end{array}$ & $\begin{array}{c}-3,545^{* * *} \\
(613)\end{array}$ & $\begin{array}{c}-3,576^{* * *} \\
(770)\end{array}$ & $\begin{array}{c}-3,503^{* * *} \\
(666)\end{array}$ & $\begin{array}{c}-3,2966^{* * *} \\
(745)\end{array}$ & $\begin{array}{c}-2,870^{* * *} \\
(385)\end{array}$ & $\begin{array}{c}-2,996^{* * *} \\
(332)\end{array}$ & $\begin{array}{c}-4,615^{* * *} \\
(704)\end{array}$ & $\begin{array}{r}-2,566 \\
(32\end{array}$ & $\begin{array}{r}-4,166 \\
(74\end{array}$ & $\begin{array}{c}-2,375^{* * *} \\
(344)\end{array}$ & $\begin{array}{r}-5,01 \\
(83\end{array}$ & $\begin{array}{r}-2,50 \\
(36\end{array}$ & $\begin{array}{c}-3,248^{* * *} \\
(498)\end{array}$ & $\begin{array}{c}-5,141^{* * * *} \\
(907)\end{array}$ \\
\hline Local cultural norms & $\begin{array}{l}5,542 * * * \\
(308)\end{array}$ & $\begin{array}{c}4,305 * * * \\
(405)\end{array}$ & $\begin{array}{l}8,027 * * * \\
(621)\end{array}$ & $\begin{array}{c}4,322 * * * \\
(318)\end{array}$ & $\begin{array}{c}9,156 * * * \\
(796)\end{array}$ & $\begin{array}{c}5,411 * * * \\
(600)\end{array}$ & $\begin{array}{c}5,7565^{* * * *} \\
(470)\end{array}$ & $\begin{array}{l}5,315 * * * \\
(607)\end{array}$ & $\begin{array}{c}7,007^{* * *} \\
(591)\end{array}$ & $\begin{array}{c}6,830^{* * *} \\
(469)\end{array}$ & $\begin{array}{c}4,985^{* * *} \\
(385)\end{array}$ & $\begin{array}{c}5,503^{* * *} \\
(361)\end{array}$ & $\begin{array}{c}6,103^{* * *} \\
(610)\end{array}$ & $\begin{array}{c}4,335 * * * \\
(393)\end{array}$ & $\begin{array}{c}7,072^{* * * *} \\
(576)\end{array}$ & $\begin{array}{c}3,906 * * * \\
(349)\end{array}$ & $\begin{array}{c}8,593 * * * \\
(801)\end{array}$ & $\begin{array}{c}5,033^{* * *} \\
(665)\end{array}$ & $\begin{array}{c}6,095 \% * * \\
(457)\end{array}$ & $\begin{array}{c}7,388^{* * *} \\
(778)\end{array}$ \\
\hline Nonpecuniary moving costs & $\begin{array}{c}-51,448 * * * \\
(2,381)\end{array}$ & $\begin{array}{c}-39,654^{* * * *} \\
(3,547)\end{array}$ & $\begin{array}{c}-69,885^{* * * *} \\
(8,926)\end{array}$ & $\begin{array}{c}-27,763 * * * \\
(1,642)\end{array}$ & $\begin{array}{c}-133,897 * * * \\
(19,583)\end{array}$ & $\begin{array}{c}-55,844^{* * *} \\
(7,290)\end{array}$ & $\begin{array}{c}-52,759^{* * * *} \\
(3,521)\end{array}$ & $\begin{array}{c}-62,221 * * * \\
(7,792)\end{array}$ & $\begin{array}{c}-57,636^{* * * *} \\
(4,093)\end{array}$ & $\begin{array}{c}-63,067 * * * \\
(5,643)\end{array}$ & $\begin{array}{c}-43,788 * * * * \\
(3,899)\end{array}$ & $\begin{array}{c}-50,395 * * * \\
(3,600)\end{array}$ & $\begin{array}{c}-56,413 * * * \\
(6,893)\end{array}$ & $\begin{array}{c}-26,612^{* * *} \\
(1,946)\end{array}$ & $\begin{array}{c}-71,207^{* * * *} \\
(6,354)\end{array}$ & $\begin{array}{c}-32,606 * * * * \\
(3,423)\end{array}$ & $\begin{array}{c}-82,521 * * * \\
(6,987)\end{array}$ & $\begin{array}{c}-37,795^{* * * *} \\
(4,901)\end{array}$ & $\begin{array}{c}-61,625^{* * *} \\
(4,664)\end{array}$ & $\begin{array}{c}-57,845^{* *}, \\
(8,173)\end{array}$ \\
\hline Observations & 48,896 & 23,568 & 25,328 & 22,600 & 26,296 & 17,936 & 30,960 & 20,760 & 28,136 & 29,400 & 19,496 & 28,360 & 20,520 & 13,976 & 34,920 & 22,096 & 26,800 & 10,800 & 22,496 & 15,600 \\
\hline
\end{tabular}

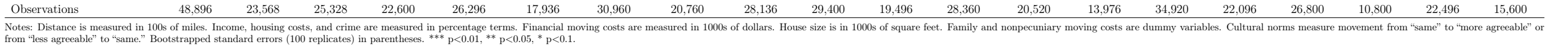


Table 8: Neighborhood choice WTP estimates (dollars; continued)

\begin{tabular}{|c|c|c|c|c|c|c|c|c|c|c|c|c|c|}
\hline Characteristic & $\begin{array}{c}(1) \\
\operatorname{Pr}(\text { move }) \geq 0.33\end{array}$ & $\begin{array}{c}(2) \\
0.03 \leq \operatorname{Pr}(\text { move }) \leq 0.32\end{array}$ & $\begin{array}{c}(3) \\
\operatorname{Pr}(\text { move }) \leq 0.02\end{array}$ & $\begin{array}{c}(4) \\
\text { tenure } \leq 5\end{array}$ & $\begin{array}{c}(5) \\
5<\text { tenure } \leq 10\end{array}$ & $\begin{array}{c}(6) \\
\text { tenure }>10\end{array}$ & $\begin{array}{c}(7) \\
\text { sqft } \leq 1500\end{array}$ & $\begin{array}{c}(8) \\
\text { sqft }>1500\end{array}$ & $\begin{array}{c}(9) \\
\frac{\text { price }}{\text { sqft }} \leq 150\end{array}$ & $\begin{array}{c}(10) \\
\text { price } \\
\frac{\text { sqft }}{}>150 \\
\end{array}$ & $\begin{array}{c}(11) \\
\text { mobile }\end{array}$ & $\begin{array}{c}(12) \\
\text { stuck }\end{array}$ & $\begin{array}{l}(13) \\
\text { rooted }\end{array}$ \\
\hline Housing costs & $\begin{array}{c}-7,601 * * * \\
(1,108)\end{array}$ & $\begin{array}{c}-12,094^{* * *} \\
(2,090)\end{array}$ & & $\begin{array}{c}-9,857^{* * *} \\
(1,878)\end{array}$ & $\begin{array}{c}-8,287^{* * *} \\
(3,054)\end{array}$ & $\begin{array}{c}-7,988^{* * *} \\
(2,445)\end{array}$ & $\begin{array}{c}-12,958^{* * *} \\
(2,290)\end{array}$ & $\begin{array}{c}-8,399^{* * *} \\
(1,457)\end{array}$ & $\begin{array}{c}-10,213^{* * *} \\
(1,733)\end{array}$ & $\begin{array}{c}-9,741^{* * *} \\
(2,299)\end{array}$ & $\begin{array}{c}-10,970^{* * *} \\
(1,415)\end{array}$ & $\begin{array}{c}-14,899^{* * *} \\
(3,169)\end{array}$ & $\begin{array}{c}-15,338 \\
(-)\end{array}$ \\
\hline Crime & $\begin{array}{c}-4,038^{* * *} \\
(456)\end{array}$ & $\begin{array}{c}-6,205^{* * *} \\
(807)\end{array}$ & $\begin{array}{c}-3,438^{* * *} \\
(19)\end{array}$ & $\begin{array}{c}-3,681^{* * *} \\
(323)\end{array}$ & $\begin{array}{c}-3,746^{* * *} \\
(507)\end{array}$ & $\begin{array}{c}-4,134^{* * *} \\
(627)\end{array}$ & $\begin{array}{c}-3,598^{* * *} \\
(206)\end{array}$ & $\begin{array}{c}-3,992^{* * *} \\
(458)\end{array}$ & $\begin{array}{c}-3,693^{* * *} \\
(296)\end{array}$ & $\begin{array}{c}-4,620 * * * \\
(475)\end{array}$ & $\begin{array}{c}-6,141^{* * *} \\
(597)\end{array}$ & $\begin{array}{c}-6,193^{* * *} \\
(1,169)\end{array}$ & $-3,476$ \\
\hline Distance & $\begin{array}{c}-515^{* * *} \\
(59)\end{array}$ & $\begin{array}{c}-737^{* * *} \\
(92)\end{array}$ & $\begin{array}{c}-638^{* * *} \\
(133)\end{array}$ & $\begin{array}{c}-570^{* * *} \\
(40)\end{array}$ & $\begin{array}{c}-667^{* * *} \\
(108)\end{array}$ & $\begin{array}{c}-742^{* * *} \\
(56)\end{array}$ & $\begin{array}{c}-646^{* * *} \\
(49)\end{array}$ & $\begin{array}{c}-647^{* * *} \\
(55)\end{array}$ & $\begin{array}{c}-603^{* * *} \\
(56)\end{array}$ & $\begin{array}{c}-754^{* * *} \\
(92)\end{array}$ & $\begin{array}{c}-409^{* * *} \\
(50)\end{array}$ & $\begin{array}{c}-517^{* * *} \\
(91)\end{array}$ & -610 \\
\hline Family nearby & $\begin{array}{c}10,832^{* * *} \\
(646)\end{array}$ & $\begin{array}{c}15,519^{* * *} \\
(1,076)\end{array}$ & $\begin{array}{c}24,381^{* * *} \\
(231)\end{array}$ & $\begin{array}{c}11,876^{* * *} \\
(782)\end{array}$ & $\begin{array}{c}16,743^{* * *} \\
(1,972)\end{array}$ & $\begin{array}{c}17,455^{* * *} \\
(1,647)\end{array}$ & $\begin{array}{c}12,162^{* * *} \\
(890)\end{array}$ & $\begin{array}{c}18,563^{* * *} \\
(861)\end{array}$ & $\begin{array}{c}14,835^{* * *} \\
(964)\end{array}$ & $\begin{array}{c}17,849^{* * *} \\
(1,317)\end{array}$ & $\begin{array}{c}8,513^{* * *} \\
(545)\end{array}$ & $\begin{array}{c}12,352^{* * *} \\
(1,558)\end{array}$ & 24,591 \\
\hline House square footage & $\begin{array}{c}1,438^{*} \\
(833)\end{array}$ & $\begin{array}{l}-612 \\
(697)\end{array}$ & $\begin{array}{c}677 \\
(903)\end{array}$ & $\begin{array}{c}3,296^{* * *} \\
(458)\end{array}$ & $\begin{array}{c}959 \\
(1,242)\end{array}$ & $\begin{array}{c}-1,671 \\
(1,417)\end{array}$ & $\begin{array}{c}2,896^{* * *} \\
(493)\end{array}$ & $\begin{array}{c}-406 \\
(930)\end{array}$ & $\begin{array}{c}2,124 * * * \\
(610)\end{array}$ & $\begin{array}{c}1,457 \\
(1,201)\end{array}$ & $\begin{array}{c}403 \\
(691)\end{array}$ & $\begin{array}{l}2,999^{*} \\
(1,592)\end{array}$ & $\begin{array}{c}2,662 \\
(-)\end{array}$ \\
\hline Financial moving costs & $\begin{array}{c}-521^{* * *} \\
(13)\end{array}$ & $\begin{array}{c}-597^{* * *} \\
(26)\end{array}$ & $\begin{array}{c}-357^{* * *} \\
(84)\end{array}$ & $\begin{array}{c}-549^{* * *} \\
(14)\end{array}$ & $\begin{array}{c}-557^{* * *} \\
(32)\end{array}$ & $\begin{array}{c}-601^{* * *} \\
(18)\end{array}$ & $\begin{array}{c}-523^{* * *} \\
(13)\end{array}$ & $\begin{array}{c}-617^{* * *} \\
(24)\end{array}$ & $\begin{array}{c}-541^{* * *} \\
(14)\end{array}$ & $\begin{array}{c}-686^{* * *} \\
(28)\end{array}$ & $\begin{array}{c}-531^{* * *} \\
(22)\end{array}$ & $\begin{array}{c}-509^{* * *} \\
(28)\end{array}$ & $\begin{array}{l}-537 \\
(-)\end{array}$ \\
\hline Taxes & $\begin{array}{c}-2,541^{* * *} \\
(285)\end{array}$ & $\begin{array}{c}-3,780^{* * *} \\
(711)\end{array}$ & $\begin{array}{c}-3,586^{* * *} \\
(770)\end{array}$ & $\begin{array}{c}-3,022^{* * *} \\
(376)\end{array}$ & $\begin{array}{c}-2,264^{* * *} \\
(402)\end{array}$ & $\begin{array}{c}-4,064^{* * *} \\
(1,034)\end{array}$ & $\begin{array}{c}-2,895^{* * *} \\
(503)\end{array}$ & $\begin{array}{c}-3,819^{* * *} \\
(707)\end{array}$ & $\begin{array}{c}-3,162^{* * *} \\
(573)\end{array}$ & $\begin{array}{c}-3,720^{* * *} \\
(782)\end{array}$ & $\begin{array}{c}-3,181^{* * *} \\
(511)\end{array}$ & $\begin{array}{c}-2,798^{* * *} \\
(809)\end{array}$ & $\begin{array}{c}-3,641 \\
(-)\end{array}$ \\
\hline Local cultural norms & $\begin{array}{c}4,620^{* * *} \\
(344)\end{array}$ & $\begin{array}{c}6,970^{* * *} \\
(643)\end{array}$ & $\begin{array}{l}31,020^{*} \\
(17,210)\end{array}$ & $\begin{array}{c}4,940^{* * *} \\
(317)\end{array}$ & $\begin{array}{c}4,793^{* * *} \\
(660)\end{array}$ & $\begin{array}{c}8,031^{* * *} \\
(850)\end{array}$ & $\begin{array}{c}4,681^{* * *} \\
(370)\end{array}$ & $\begin{array}{c}7,094^{* * * *} \\
(613)\end{array}$ & $\begin{array}{c}4,920^{* * *} \\
(485)\end{array}$ & $\begin{array}{c}7,018^{* * *} \\
(690)\end{array}$ & $\begin{array}{c}5,522^{* * *} \\
(407)\end{array}$ & $\begin{array}{c}5,207^{* * *} \\
(925)\end{array}$ & $\begin{array}{l}7,588 \\
(-)\end{array}$ \\
\hline Nonpecuniary moving costs & $\begin{array}{c}-16,464^{* * *} \\
(1,282)\end{array}$ & $\begin{array}{c}-48,476^{* * *} \\
(5,480)\end{array}$ & $\begin{array}{c}-2.71688 \mathrm{e}+27 \\
(1.36001 \mathrm{e}+29)\end{array}$ & $\begin{array}{c}-30,931^{* * *} \\
(1,437)\end{array}$ & $\begin{array}{c}-57,965^{* * *} \\
(10,779)\end{array}$ & $\begin{array}{c}-100,046^{* * *} \\
(15,385)\end{array}$ & $\begin{array}{c}-38,931 \text { *** } \\
(3,911)\end{array}$ & $\begin{array}{c}-71,399^{* * *} \\
(5,383)\end{array}$ & $\begin{array}{c}-49,131^{* * *} \\
(4,816)\end{array}$ & $\begin{array}{c}-66,676^{* * *} \\
(6,167)\end{array}$ & $\begin{array}{c}-15,509^{* * *} \\
(1,092)\end{array}$ & $\begin{array}{c}-39,739^{* * *} \\
(5,942)\end{array}$ & $\begin{array}{c}-13,709,910 \\
(-)\end{array}$ \\
\hline Observations & 16,320 & 16,736 & 15,840 & 19,824 & 8,712 & 20,360 & 24,872 & 23,520 & 22,688 & 18,216 & 18,760 & 6,000 & 24,104 \\
\hline
\end{tabular}


Table 9: Neighborhood choice WTP estimates (percentage of income)

\begin{tabular}{|c|c|c|c|c|c|c|c|c|c|c|c|c|c|c|c|c|c|c|c|c|}
\hline Characteristic & $\begin{array}{l}(1) \\
\text { all } \\
\end{array}$ & $\begin{array}{c}(2) \\
\text { female }\end{array}$ & $\begin{array}{c}(3) \\
\text { male }\end{array}$ & $\begin{array}{c}(4) \\
\text { young }\end{array}$ & $\begin{array}{l}(5) \\
\text { old } \\
\end{array}$ & $\begin{array}{c}(6) \\
\text { not married } \\
\end{array}$ & $\begin{array}{c}(7) \\
\text { married }\end{array}$ & $\begin{array}{c}(8) \\
\text { not coll grad }\end{array}$ & $\begin{array}{c}(9) \\
\text { coll grad } \\
\end{array}$ & $\begin{array}{c}(10) \\
\text { no kids }\end{array}$ & $\begin{array}{l}\text { (11) } \\
\text { kids }\end{array}$ & $\begin{array}{c}\begin{array}{c}(12) \\
\text { healthy }\end{array} \\
\text { hel }\end{array}$ & $\begin{array}{c}(13) \\
\text { less healthy }\end{array}$ & $\begin{array}{l}(14) \\
\text { renter }\end{array}$ & $\begin{array}{c}(15) \\
\text { owner }\end{array}$ & $\begin{array}{l}(16) \\
\text { poor }\end{array}$ & $\begin{array}{l}(17) \\
\text { rich }\end{array}$ & $\begin{array}{l}(18) \\
\text { city }\end{array}$ & $\begin{array}{l}(19) \\
\text { suburb } \\
\end{array}$ & $\begin{array}{l}(20) \\
\text { rural }\end{array}$ \\
\hline Housing costs & $\begin{array}{c}-20.13^{* * *} \\
(2.64)\end{array}$ & $\begin{array}{c}-20.78^{* * *} \\
(4.30)\end{array}$ & $\begin{array}{c}-19.15^{* * *} \\
(4.24)\end{array}$ & $\begin{array}{c}-14.97 * * * \\
(2.06)\end{array}$ & $\begin{array}{c}-27.81 * * * \\
(7.06)\end{array}$ & $\begin{array}{c}-28.61^{* * *} \\
(6.86)\end{array}$ & $\begin{array}{c}-16.43 * * * \\
(2.05)\end{array}$ & $\begin{array}{c}-17.87^{* * *} \\
(5.85)\end{array}$ & $\begin{array}{c}-21.08^{* * *} \\
(2.86)\end{array}$ & $\begin{array}{c}-25.84^{* * *} \\
(5.16)\end{array}$ & $\begin{array}{c}-14.89^{* * * *} \\
(2.57)\end{array}$ & $\begin{array}{c}-21.92^{* * * *} \\
(3.75)\end{array}$ & $\begin{array}{c}-18.02^{* * *} \\
(4.12)\end{array}$ & $\begin{array}{c}-25.35 * * * \\
(5.97)\end{array}$ & $\begin{array}{c}-18.18 * * * \\
(2.66)\end{array}$ & $\begin{array}{c}-24.93^{* * * *} \\
(3.96)\end{array}$ & $\begin{array}{c}-16.28^{* * *} \\
(3.14)\end{array}$ & $\begin{array}{l}-17.82^{* * * *} \\
(4.60)\end{array}$ & $\begin{array}{c}-16.39^{* * * *} \\
(2.47)\end{array}$ & $\begin{array}{c}-34.54^{* * * *} \\
(8.11)\end{array}$ \\
\hline Crime & $\begin{array}{c}-7.86^{* * * *} \\
(0.39)\end{array}$ & $\begin{array}{c}-8.25^{* * *} \\
(0.23)\end{array}$ & $\begin{array}{c}-9.67^{* * * *} \\
(1.35)\end{array}$ & $\begin{array}{c}-8.00^{* * * *} \\
(0.50)\end{array}$ & $\begin{array}{c}-9.15^{* * *} \\
(0.64)\end{array}$ & $\begin{array}{c}-8.25^{* * *} \\
(0.30)\end{array}$ & $\begin{array}{c}-8.52^{* * *} \\
(0.62)\end{array}$ & $\begin{array}{c}-8.25^{* * *} \\
(0.33)\end{array}$ & $\begin{array}{c}-7.88^{* * * *} \\
(0.86)\end{array}$ & $\begin{array}{c}-8.25^{* * *} \\
(0.58)\end{array}$ & $\begin{array}{c}-8.14^{* * *} \\
(0.70)\end{array}$ & $\begin{array}{c}-7.39^{* * * *} \\
(0.53)\end{array}$ & $\begin{array}{c}-8.25^{* * *} \\
(0.55)\end{array}$ & $\begin{array}{c}-8.25^{* * *} \\
(0.45)\end{array}$ & $\begin{array}{c}-7.94^{* * *} \\
(0.93)\end{array}$ & $\begin{array}{c}-8.25^{* * * *} \\
(0.26)\end{array}$ & $\begin{array}{c}-8.50^{* * * *} \\
(1.06)\end{array}$ & $\begin{array}{c}-8.93 * * * \\
(1.13)\end{array}$ & $\begin{array}{c}-8.06^{* * *} \\
(0.63)\end{array}$ & $\begin{array}{c}-8.25^{* * * *} \\
(0.82)\end{array}$ \\
\hline Distance & $\begin{array}{c}-1.28^{* * * *} \\
(0.13)\end{array}$ & $\begin{array}{c}-1.48^{* * * *} \\
(0.07)\end{array}$ & $\begin{array}{c}-1.06^{* * *} \\
(0.17)\end{array}$ & $\begin{array}{c}-1.15^{* * * *} \\
(0.08)\end{array}$ & $\begin{array}{c}-1.66^{* * *} \\
(0.21)\end{array}$ & $\begin{array}{c}-1.48^{* * * *} \\
(0.08)\end{array}$ & $\begin{array}{c}-1.11^{* * *} \\
(0.08)\end{array}$ & $\begin{array}{c}-1.48^{* * * *} \\
(0.08)\end{array}$ & $\begin{array}{c}-1.15^{* * *} \\
(0.07)\end{array}$ & $\begin{array}{c}-1.48^{* * *} \\
(0.13)\end{array}$ & $\begin{array}{c}-1.19^{* * * *} \\
(0.08)\end{array}$ & $\begin{array}{c}-1.13^{* * * *} \\
(0.09)\end{array}$ & $\begin{array}{c}-1.48^{* * *} \\
(0.10)\end{array}$ & $\begin{array}{c}-1.48^{* * *} \\
(0.13)\end{array}$ & $\begin{array}{c}-1.32^{* * * *} \\
(0.14)\end{array}$ & $\begin{array}{c}-1.48^{* * * *} \\
(0.10)\end{array}$ & $\begin{array}{c}-1.12^{* * *} \\
(0.10)\end{array}$ & $\begin{array}{c}-1.48^{* * * *} \\
(0.15)\end{array}$ & $\begin{array}{c}-1.19^{* * * *} \\
(0.09)\end{array}$ & $\begin{array}{c}-1.48^{* * * *} \\
(0.13)\end{array}$ \\
\hline Family nearby & $\begin{array}{c}28.99^{* * *} \\
(1.23)\end{array}$ & $\begin{array}{c}32.30^{* * * *} \\
(1.97)\end{array}$ & $\begin{array}{c}28.35 * * * \\
(1.96)\end{array}$ & $\begin{array}{c}24.03^{* * * *} \\
(1.26)\end{array}$ & $\begin{array}{c}39.88^{* * * *} \\
(2.92)\end{array}$ & $\begin{array}{c}28.33^{* * * *} \\
(2.33)\end{array}$ & $\begin{array}{c}30.40^{* * * *} \\
(1.41)\end{array}$ & $\begin{array}{c}34.60^{* * * *} \\
(2.91)\end{array}$ & $\begin{array}{c}28.43^{* * * *} \\
(1.55)\end{array}$ & $\begin{array}{c}31.75 * * * \\
(2.04)\end{array}$ & $\begin{array}{c}28.25^{* * * *} \\
(1.90)\end{array}$ & $\begin{array}{c}28.48^{* * * *} \\
(1.58)\end{array}$ & $\begin{array}{c}30.55^{* * *} \\
(2.27)\end{array}$ & $\begin{array}{c}25.80^{* * * *} \\
(1.69)\end{array}$ & $\begin{array}{c}32.09 * * * \\
(1.77)\end{array}$ & $\begin{array}{c}27.55^{* * *} \\
(1.80)\end{array}$ & $\begin{array}{c}31.60^{* * * *} \\
(1.58)\end{array}$ & $\begin{array}{c}29.47 * * * \\
(2.87)\end{array}$ & $\begin{array}{c}28.89 * * * \\
(1.70)\end{array}$ & $\begin{array}{c}32.34^{* * *} \\
(2.73)\end{array}$ \\
\hline House square footage & $\begin{array}{c}2.95 * * * \\
(1.11)\end{array}$ & $\begin{array}{c}5.00 * * * \\
(1.04)\end{array}$ & $\begin{array}{l}0.57 \\
(2.09)\end{array}$ & $\begin{array}{c}6.70 * * * \\
(0.82)\end{array}$ & $\begin{array}{c}-4.74 * * * \\
(1.28)\end{array}$ & $\begin{array}{l}0.85 \\
(2.80)\end{array}$ & $\begin{array}{l}3.05^{* * *} \\
(1.21)\end{array}$ & $\begin{array}{l}4.89 * * * \\
(1.39)\end{array}$ & $\begin{array}{l}0.86 \\
(1.52)\end{array}$ & $\begin{array}{l}-1.98 \\
(1.96)\end{array}$ & $\begin{array}{c}6.90 * * * \\
(0.94)\end{array}$ & $\begin{array}{l}2.41 \\
(1.60)\end{array}$ & $\begin{array}{c}4.45 * * * \\
(1.53)\end{array}$ & $\begin{array}{c}7.38^{* * * *} \\
(2.71)\end{array}$ & $\begin{array}{l}0.13 \\
(1.79)\end{array}$ & $\begin{array}{c}5.08 * * * \\
(1.34)\end{array}$ & $\begin{array}{l}1.28 \\
(2.05)\end{array}$ & $\begin{array}{l}3.25 \\
(2.11)\end{array}$ & $\begin{array}{c}5.64 * * * \\
(1.34)\end{array}$ & $\begin{array}{l}-0.70 \\
(2.70)\end{array}$ \\
\hline Financial moving costs & $\begin{array}{c}-1.16^{* * *} \\
(0.03)\end{array}$ & $\begin{array}{c}-1.20^{* * *} \\
(0.02)\end{array}$ & $\begin{array}{c}-1.09 * * * \\
(0.14)\end{array}$ & $\begin{array}{c}-1.13^{* * * *} \\
(0.03)\end{array}$ & $\begin{array}{c}-1.28^{* * * *} \\
(0.06)\end{array}$ & $\begin{array}{c}-1.20^{* * *} \\
(0.02)\end{array}$ & $\begin{array}{c}-1.11^{* * *} \\
(0.03)\end{array}$ & $\begin{array}{c}-1.20^{* * *} \\
(0.03)\end{array}$ & $\begin{array}{c}-1.13^{* * *} \\
(0.03)\end{array}$ & $\begin{array}{c}-1.20^{* * *} \\
(0.04)\end{array}$ & $\begin{array}{c}-1.15^{* * * *} \\
(0.02)\end{array}$ & $\begin{array}{c}-1.12^{* * *} \\
(0.03)\end{array}$ & $\begin{array}{c}-1.20^{* * * *} \\
(0.02)\end{array}$ & $\begin{array}{c}-1.20^{* * *} \\
(0.03)\end{array}$ & $\begin{array}{c}-1.17^{* * * *} \\
(0.04)\end{array}$ & $\begin{array}{c}-1.22^{* * * *} \\
(0.02)\end{array}$ & $\begin{array}{c}-1.11^{* * * *} \\
(0.03)\end{array}$ & $\begin{array}{c}-1.20^{* * * *} \\
(0.04)\end{array}$ & $\begin{array}{c}-1.15^{* * * *} \\
(0.03)\end{array}$ & $\begin{array}{c}-1.20^{* * * *} \\
(0.03)\end{array}$ \\
\hline Taxes & $\begin{array}{c}-6.83^{* * *} \\
(0.94)\end{array}$ & $\begin{array}{c}-5.38^{* * * *} \\
(0.93)\end{array}$ & $\begin{array}{c}-7.05^{* * * *} \\
(1.47)\end{array}$ & $\begin{array}{c}-5.00^{* * * *} \\
(0.40)\end{array}$ & $\begin{array}{c}-10.04^{* * * *} \\
(2.41)\end{array}$ & $\begin{array}{c}-6.82^{* * * *} \\
(1.65)\end{array}$ & $\begin{array}{c}-6.81^{* * *} \\
(1.18)\end{array}$ & $\begin{array}{c}-7.90^{* * * *} \\
(1.70)\end{array}$ & $\begin{array}{c}-5.92^{* * * *} \\
(1.13)\end{array}$ & $\begin{array}{c}-7.07^{* * *} \\
(1.60)\end{array}$ & $\begin{array}{c}-5.60^{* * * *} \\
(0.75)\end{array}$ & $\begin{array}{c}-5.67^{* * * *} \\
(0.63)\end{array}$ & $\begin{array}{c}-10.37^{* * *} \\
(1.58)\end{array}$ & $\begin{array}{c}-6.02^{* * *} \\
(0.77)\end{array}$ & $\begin{array}{c}-8.03^{* * * *} \\
(1.44)\end{array}$ & $\begin{array}{c}-6.36^{* * *} \\
(0.92)\end{array}$ & $\begin{array}{c}-7.54^{* * *} \\
(1.25)\end{array}$ & $\begin{array}{c}-6.00^{* * * *} \\
(0.86)\end{array}$ & $\begin{array}{c}-5.44^{* * *} \\
(0.83)\end{array}$ & $\begin{array}{c}-11.90^{* * * *} \\
(2.10)\end{array}$ \\
\hline Local cultural norms & $\begin{array}{c}11.41^{* * *} \\
(0.63)\end{array}$ & $\begin{array}{c}9.37 * * * \\
(0.88)\end{array}$ & $\begin{array}{c}15.60^{* * * *} \\
(1.21)\end{array}$ & $\begin{array}{c}8.96^{* * * *} \\
(0.66)\end{array}$ & $\begin{array}{c}18.68 * * * \\
(1.62)\end{array}$ & $\begin{array}{c}12.48 * * * \\
(1.38)\end{array}$ & $\begin{array}{c}11.05^{* * *} \\
(0.90)\end{array}$ & $\begin{array}{c}11.74^{* * *} \\
(1.34)\end{array}$ & $\begin{array}{c}11.88^{* * *} \\
(1.00)\end{array}$ & $\begin{array}{c}14.66 * * * \\
(1.01)\end{array}$ & $\begin{array}{c}9.72 * * * \\
(0.75)\end{array}$ & $\begin{array}{c}10.42^{* * * *} \\
(0.68)\end{array}$ & $\begin{array}{c}13.71^{* * *} \\
(1.37)\end{array}$ & $\begin{array}{c}10.17^{* * *} \\
(0.92)\end{array}$ & $\begin{array}{c}13.62^{* * * *} \\
(1.11)\end{array}$ & $\begin{array}{c}10.46 * * * \\
(0.94)\end{array}$ & $\begin{array}{c}12.92^{2 * * *} \\
(1.20)\end{array}$ & $\begin{array}{c}12.03^{* * *} \\
(1.59)\end{array}$ & $\begin{array}{c}10.20^{* * * *} \\
(0.77)\end{array}$ & $\begin{array}{c}17.10^{* * * *} \\
(1.80)\end{array}$ \\
\hline Nonpecuniary moving costs & $\begin{array}{c}-105.92^{* * * *} \\
(4.90)\end{array}$ & $\begin{array}{c}-86.28^{* * * *} \\
(7.72)\end{array}$ & $\begin{array}{c}-135.85 * * * \\
(17.35)\end{array}$ & $\begin{array}{c}-57.56^{* * * *} \\
(3.40)\end{array}$ & $\begin{array}{c}-273.19^{* * * *} \\
(39.96)\end{array}$ & $\begin{array}{c}-128.78 * * * \\
(16.81)\end{array}$ & $\begin{array}{c}-101.32 * * * \\
(6.76)\end{array}$ & $\begin{array}{c}-137.39 * * * \\
(17.21)\end{array}$ & $\begin{array}{c}-97.36 \text { **** } \\
(6.91)\end{array}$ & $\begin{array}{c}-135.36^{* * *} \\
(12.11)\end{array}$ & $\begin{array}{c}-85.41 \text { **** } \\
(7.60)\end{array}$ & $\begin{array}{c}-95.40^{* * * *} \\
(6.82)\end{array}$ & $\begin{array}{c}-126.72^{* * * *} \\
(15.48)\end{array}$ & $\begin{array}{c}-62.46 \text { *** } \\
(4.57)\end{array}$ & $\begin{array}{c}-137.16^{* * * *} \\
(12.24)\end{array}$ & $\begin{array}{c}-87.32 * * * * \\
(9.17)\end{array}$ & $\begin{array}{c}-124.11^{* * *} \\
(10.51)\end{array}$ & $\begin{array}{c}-90.33 * * * \\
(11.71)\end{array}$ & $\begin{array}{c}-103.17^{* * *} \\
(7.81)\end{array}$ & $\begin{array}{c}-133.89 * * * * \\
(18.92)\end{array}$ \\
\hline Observations & 48,896 & 23,568 & 25,328 & 22,600 & 26,296 & 17,936 & 30,960 & 20,760 & 28,136 & 29,400 & 19,496 & 28,360 & 20,520 & 13,976 & 34,920 & 22,096 & 26,800 & 10,800 & 22,496 & 15,600 \\
\hline
\end{tabular}


Table 10: Neighborhood choice WTP estimates (percentage of income; continued)

\begin{tabular}{|c|c|c|c|c|c|c|c|c|c|c|c|c|c|}
\hline Characteristic & $\begin{array}{c}(1) \\
\operatorname{Pr}(\text { move }) \geq 0.33\end{array}$ & $\begin{array}{c}(2) \\
0.03 \leq \operatorname{Pr}(\text { move }) \leq 0.32\end{array}$ & $\begin{array}{c}(3) \\
\operatorname{Pr}(\text { move }) \leq 0.02\end{array}$ & $\begin{array}{c}(4) \\
\text { tenure } \leq 5\end{array}$ & $\begin{array}{c}(5) \\
5<\text { tenure } \leq 10\end{array}$ & $\begin{array}{c}(6) \\
\text { tenure }>10\end{array}$ & $\begin{array}{c}(7) \\
\mathrm{sqft} \leq 1500\end{array}$ & $\begin{array}{c}(8) \\
\text { sqft }>1500\end{array}$ & $\begin{array}{c}(9) \\
\text { price } \\
\text { ssft } \leq 150\end{array}$ & $\begin{array}{c}(10) \\
\frac{\text { price }}{\text { sqft }}>150\end{array}$ & $\begin{array}{c}(11) \\
\text { mobile }\end{array}$ & $\begin{array}{l}(12) \\
\text { stuck }\end{array}$ & $\begin{array}{l}(13) \\
\text { rooted }\end{array}$ \\
\hline Housing costs & $\begin{array}{c}-16.31^{* * *} \\
(2.38)\end{array}$ & $\begin{array}{c}-24.30^{* * *} \\
(4.20)\end{array}$ & $\begin{array}{l}-64.21 \\
(113.40)\end{array}$ & $\begin{array}{l}-20.64^{* * *} \\
(3.93)\end{array}$ & $\begin{array}{c}-17.21^{* * *} \\
(6.34)\end{array}$ & $\begin{array}{c}-15.94^{* * *} \\
(4.88)\end{array}$ & $\begin{array}{l}-29.72^{* * *} \\
(5.25)\end{array}$ & $\begin{array}{c}-14.78^{* * *} \\
(2.57)\end{array}$ & $\begin{array}{c}-22.04^{* * *} \\
(3.74)\end{array}$ & $\begin{array}{c}-16.44^{* * *} \\
(3.88)\end{array}$ & $\begin{array}{c}-22.42^{* * *} \\
(2.89)\end{array}$ & $\begin{array}{c}-32.85^{* * *} \\
(6.99)\end{array}$ & $\begin{array}{c}-31.00 \\
(-)\end{array}$ \\
\hline Crime & $\begin{array}{c}-8.67^{* * *} \\
(0.98)\end{array}$ & $\begin{array}{c}-12.47^{* * *} \\
(1.62)\end{array}$ & $\begin{array}{c}-7.03^{* * *} \\
(0.04)\end{array}$ & $\begin{array}{c}-7.71^{* * *} \\
(0.68)\end{array}$ & $\begin{array}{c}-7.78^{* * *} \\
(1.05)\end{array}$ & $\begin{array}{c}-8.25^{* * *} \\
(1.25)\end{array}$ & $\begin{array}{l}-8.25^{* * *} \\
(0.47)\end{array}$ & $\begin{array}{c}-7.03^{* * *} \\
(0.81)\end{array}$ & $\begin{array}{c}-7.97^{* * *} \\
(0.64)\end{array}$ & $\begin{array}{c}-7.80^{* * *} \\
(0.80)\end{array}$ & $\begin{array}{c}-12.55^{* * *} \\
(1.22)\end{array}$ & $\begin{array}{c}-13.65^{* * *} \\
(2.58)\end{array}$ & $\begin{array}{c}-7.03 \\
(-)\end{array}$ \\
\hline Distance & $\begin{array}{c}-1.11^{* * *} \\
(0.13)\end{array}$ & $\begin{array}{c}-1.48^{* * *} \\
(0.19)\end{array}$ & $\begin{array}{c}-1.30^{* * *} \\
(0.27)\end{array}$ & $\begin{array}{c}-1.19^{* * * *} \\
(0.08)\end{array}$ & $\begin{array}{c}-1.39^{* * *} \\
(0.22)\end{array}$ & $\begin{array}{c}-1.48^{* * *} \\
(0.11)\end{array}$ & $\begin{array}{c}-1.48^{* * *} \\
(0.11)\end{array}$ & $\begin{array}{c}-1.14^{* * *} \\
(0.10)\end{array}$ & $\begin{array}{c}-1.30^{* * *} \\
(0.12)\end{array}$ & $\begin{array}{c}-1.27^{* * *} \\
(0.16)\end{array}$ & $\begin{array}{c}-0.84^{* * *} \\
(0.10)\end{array}$ & $\begin{array}{c}-1.14^{* * *} \\
(0.20)\end{array}$ & $\begin{array}{c}-1.23 \\
(-)\end{array}$ \\
\hline Family nearby & $\begin{array}{c}23.25^{* * *} \\
(1.39)\end{array}$ & $\begin{array}{c}31.19^{* * *} \\
(2.16)\end{array}$ & $\begin{array}{c}49.83^{* * *} \\
(0.47)\end{array}$ & $\begin{array}{c}24.86 * * * \\
(1.64)\end{array}$ & $\begin{array}{c}34.76^{* * * *} \\
(4.09)\end{array}$ & $\begin{array}{c}34.84^{* * *} \\
(3.29)\end{array}$ & $\begin{array}{c}27.89^{* * *} \\
(2.04)\end{array}$ & $\begin{array}{c}32.67 * * * \\
(1.51)\end{array}$ & $\begin{array}{c}32.02^{* * *} \\
(2.08)\end{array}$ & $\begin{array}{c}30.13 * * * \\
(2.22)\end{array}$ & $\begin{array}{c}17.40^{* * *} \\
(1.11)\end{array}$ & $\begin{array}{c}27.23^{* * *} \\
(3.44)\end{array}$ & $\begin{array}{l}49.70 \\
(-)\end{array}$ \\
\hline House square footage & $\begin{array}{l}3.09^{*} \\
(1.79)\end{array}$ & $\begin{array}{l}-1.23 \\
(1.40)\end{array}$ & $\begin{array}{c}1.38 \\
(1.84)\end{array}$ & $\begin{array}{c}6.90^{* * * *} \\
(0.96)\end{array}$ & $\begin{array}{c}1.99 \\
(2.58)\end{array}$ & $\begin{array}{l}-3.33 \\
(2.83)\end{array}$ & $\begin{array}{c}6.64^{* * *} \\
(1.13)\end{array}$ & $\begin{array}{l}-0.72 \\
(1.64)\end{array}$ & $\begin{array}{c}4.58^{* * *} \\
(1.32)\end{array}$ & $\begin{array}{c}2.46 \\
(2.03)\end{array}$ & $\begin{array}{c}0.82 \\
(1.41)\end{array}$ & $\begin{array}{l}6.61^{*} \\
(3.51)\end{array}$ & $\begin{array}{l}5.38 \\
(-)\end{array}$ \\
\hline Financial moving costs & $\begin{array}{c}-1.12^{* * *} \\
(0.03)\end{array}$ & $\begin{array}{c}-1.20^{* * *} \\
(0.05)\end{array}$ & $\begin{array}{c}-0.73^{* * *} \\
(0.17)\end{array}$ & $\begin{array}{c}-1.15^{* * *} \\
(0.03)\end{array}$ & $\begin{array}{c}-1.16^{* * *} \\
(0.07)\end{array}$ & $\begin{array}{c}-1.20^{* * *} \\
(0.04)\end{array}$ & $\begin{array}{c}-1.20^{* * *} \\
(0.03)\end{array}$ & $\begin{array}{c}-1.09^{* * *} \\
(0.04)\end{array}$ & $\begin{array}{c}-1.17^{* * *} \\
(0.03)\end{array}$ & $\begin{array}{c}-1.16^{* * *} \\
(0.05)\end{array}$ & $\begin{array}{c}-1.09^{* * *} \\
(0.04)\end{array}$ & $\begin{array}{c}-1.12^{* * *} \\
(0.06)\end{array}$ & $\begin{array}{c}-1.09 \\
(-)\end{array}$ \\
\hline Taxes & $\begin{array}{c}-5.45^{* * *} \\
(0.61)\end{array}$ & $\begin{array}{c}-7.60^{* * *} \\
(1.43)\end{array}$ & $\begin{array}{c}-7.33^{* * *} \\
(1.57)\end{array}$ & $\begin{array}{c}-6.33^{* * *} \\
(0.79)\end{array}$ & $\begin{array}{c}-4.70^{* * * *} \\
(0.83)\end{array}$ & $\begin{array}{c}-8.11^{* * * *} \\
(2.06)\end{array}$ & $\begin{array}{c}-6.64^{* * *} \\
(1.15)\end{array}$ & $\begin{array}{c}-6.72^{* * *} \\
(1.24)\end{array}$ & $\begin{array}{c}-6.82 * * * \\
(1.24)\end{array}$ & $\begin{array}{c}-6.28 * * * \\
(1.32)\end{array}$ & $\begin{array}{c}-6.50^{* * *} \\
(1.04)\end{array}$ & $\begin{array}{c}-6.17^{* * *} \\
(1.78)\end{array}$ & $\begin{array}{c}-7.36 \\
(-)\end{array}$ \\
\hline Local cultural norms & $\begin{array}{c}9.91^{* * *} \\
(0.74)\end{array}$ & $\begin{array}{c}14.01^{* * * *} \\
(1.29)\end{array}$ & $\begin{array}{l}63.40^{*} \\
(35.17)\end{array}$ & $\begin{array}{c}10.34^{* * *} \\
(0.66)\end{array}$ & $\begin{array}{c}9.95^{* * *} \\
(1.37)\end{array}$ & $\begin{array}{c}16.03^{* * *} \\
(1.70)\end{array}$ & $\begin{array}{c}10.74^{* * *} \\
(0.85)\end{array}$ & $\begin{array}{c}12.49^{* * *} \\
(1.08)\end{array}$ & $\begin{array}{c}10.62^{* * *} \\
(1.05)\end{array}$ & $\begin{array}{c}11.85^{* * *} \\
(1.16)\end{array}$ & $\begin{array}{c}11.29 * * * \\
(0.83)\end{array}$ & $\begin{array}{c}11.48^{* * *} \\
(2.04)\end{array}$ & $\begin{array}{c}15.34 \\
(-)\end{array}$ \\
\hline Nonpecuniary moving costs & $\begin{array}{c}-35.34^{* * *} \\
(2.75)\end{array}$ & $\begin{array}{c}-97.42^{* * *} \\
(11.01)\end{array}$ & $\begin{array}{c}-5.55 \mathrm{e}+24 \\
(2.78 \mathrm{e}+26)\end{array}$ & $\begin{array}{c}-64.76^{* * *} \\
(3.01)\end{array}$ & $\begin{array}{c}-120.35^{* * *} \\
(22.38)\end{array}$ & $\begin{array}{c}-199.71^{* * *} \\
(30.71)\end{array}$ & $\begin{array}{c}-89.29^{* * *} \\
(8.97)\end{array}$ & $\begin{array}{c}-125.66^{* * *} \\
(9.47)\end{array}$ & $\begin{array}{c}-106.04^{* * *} \\
(10.39)\end{array}$ & $\begin{array}{c}-112.56^{* * *} \\
(10.41)\end{array}$ & $\begin{array}{c}-31.70^{* * *} \\
(2.23)\end{array}$ & $\begin{array}{c}-87.61^{* * *} \\
(13.10)\end{array}$ & $\begin{array}{c}-27,711.34 \\
(-)\end{array}$ \\
\hline Observations & 16,320 & 16,736 & 15,840 & 19,824 & 8,712 & 20,360 & 24,872 & 23,520 & 22,688 & 18,216 & 18,760 & 6,000 & 24,104 \\
\hline
\end{tabular}

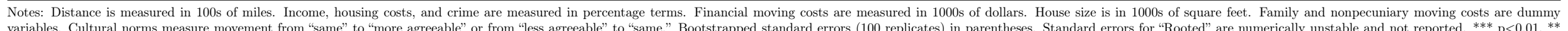

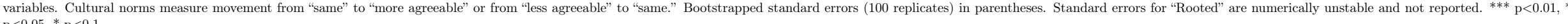


Figure 8: Distribution of median $W T P_{i}$ by small group
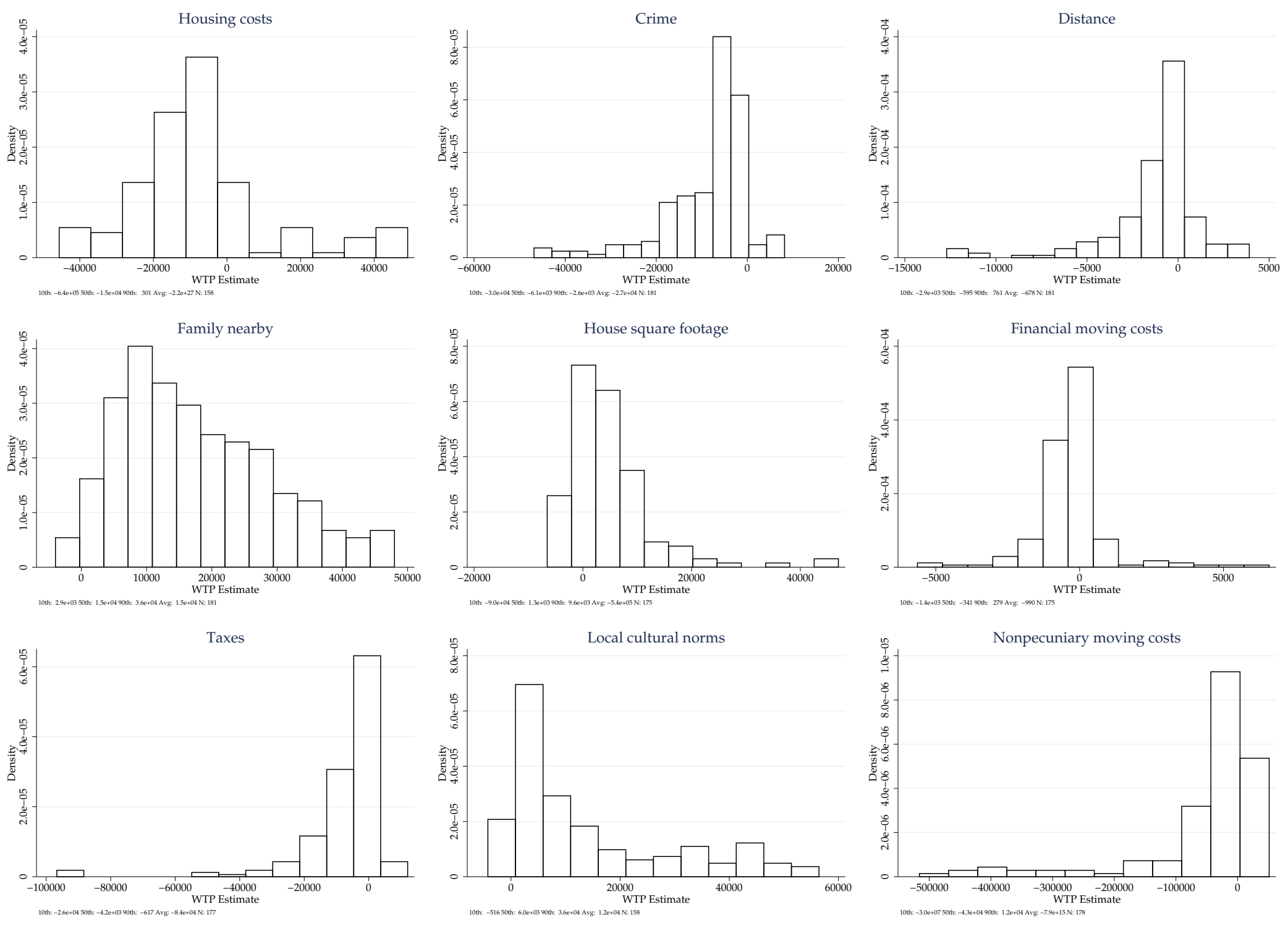


\section{Online Appendix}

\section{A Data appendix}

Table A1: Distribution of scenarios per person

\begin{tabular}{lcc}
\hline Number of scenarios & Number of individuals & Percent of sample \\
\hline 8 & 878 & 44.16 \\
16 & 873 & 43.91 \\
24 & 237 & 11.92 \\
\hline Total & 1,988 & 100.00 \\
\hline
\end{tabular}

Note: This table lists the distribution of scenarios per person. Individuals in the January wave answer up to 8 scenarios, while those in the September wave answer up to 16 scenarios. About $12 \%$ of the sample is included in both waves and can answer up to 24 scenarios.

Figure A1: Detailed reasons for moving, 1999-2018

(a) Family and Employment

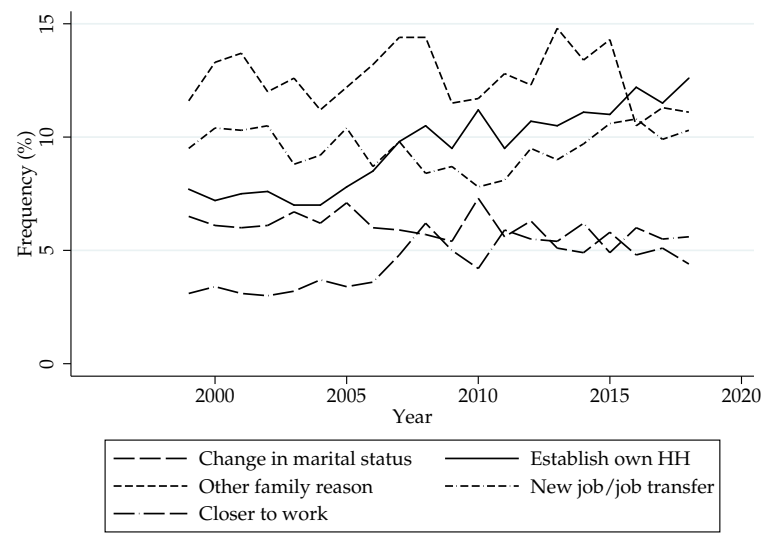

(b) Housing

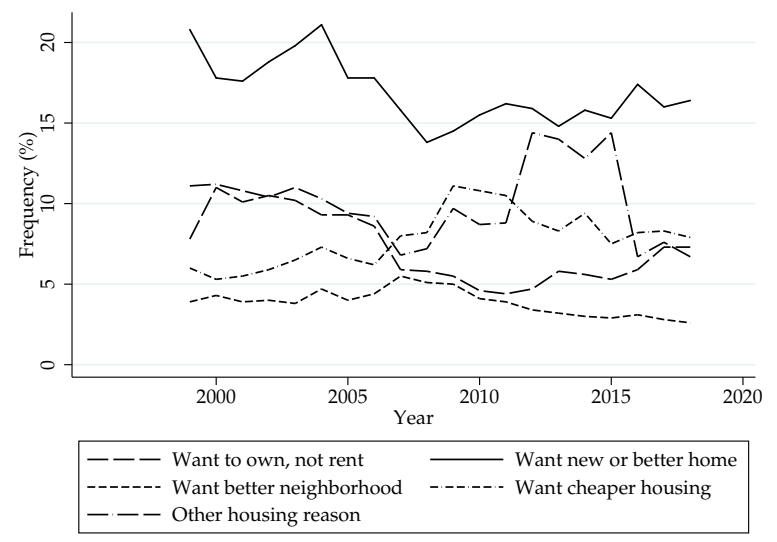

Source: US Census Bureau Current Population Survey (CPS). https://www . census.gov/data/tables/time-series/demo/geographic-mobility/historic.html 
Figure A2: Distribution of subjective choice probabilities, by SCE wave and choice alternative

(a) January, Alt 1

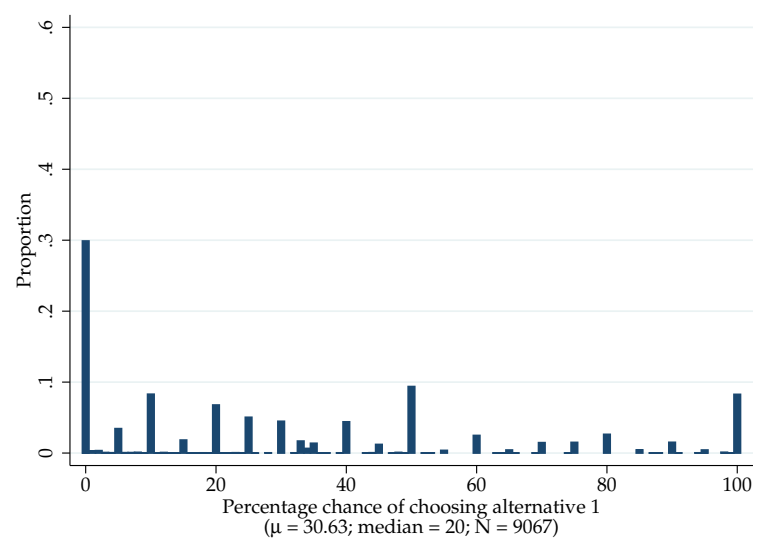

(c) January, Alt 2

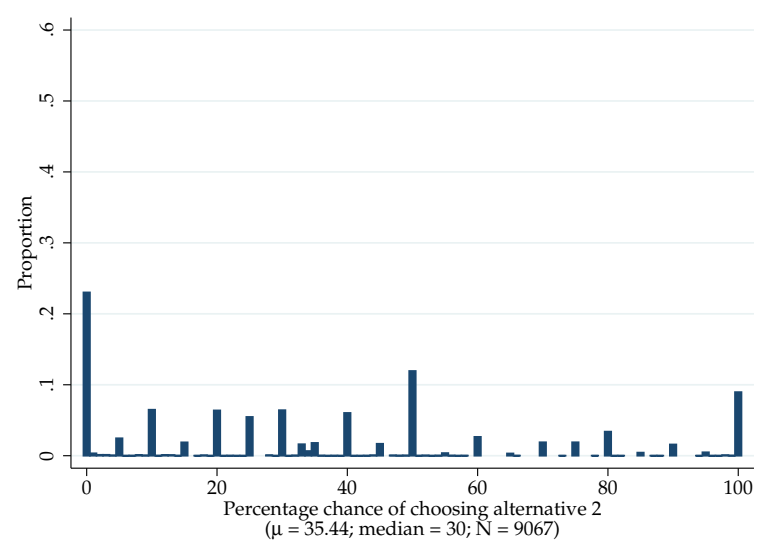

(e) January, Alt 3

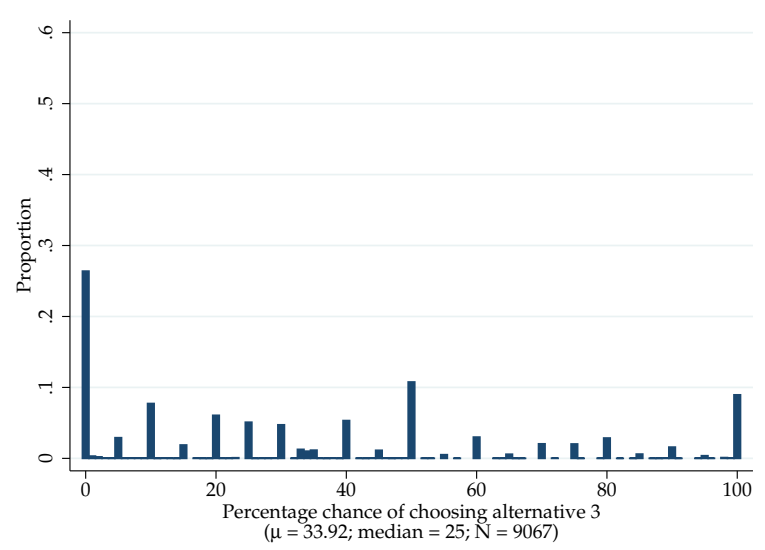

(b) September, Alt1

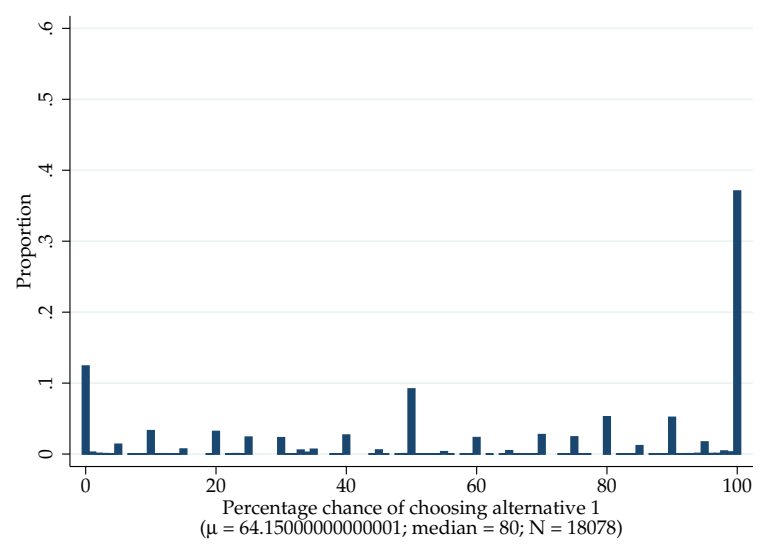

(d) September, Alt 2

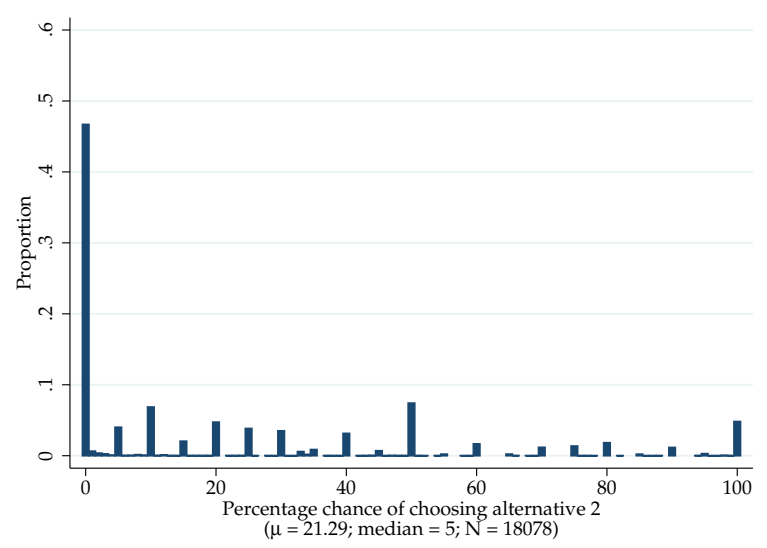

(f) September, Alt 3

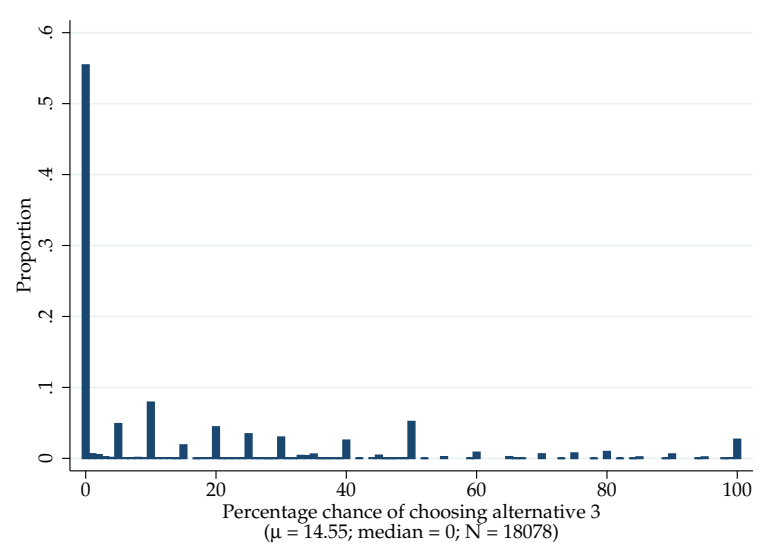

Source: Survey of Consumer Expectations collected in January and September 2018. 
Table A2: Choice model estimates (January wave only)

\begin{tabular}{|c|c|c|c|c|c|c|c|c|c|c|c|c|c|c|c|c|c|c|c|c|c|c|c|}
\hline VARIABLES & $\begin{array}{l}\text { (1) } \\
\text { all }\end{array}$ & $\begin{array}{c}(2) \\
\text { female }\end{array}$ & $\begin{array}{l}(3) \\
\text { male }\end{array}$ & $\begin{array}{l}(4) \\
\text { young }\end{array}$ & $\begin{array}{l}\text { (5) } \\
\text { old }\end{array}$ & $\begin{array}{c}(6) \\
\text { not married }\end{array}$ & $\begin{array}{c}(7) \\
\text { married }\end{array}$ & $\begin{array}{c}\text { (8) } \\
\text { not coll grad }\end{array}$ & $\begin{array}{c}9) \\
\text { coll grad }\end{array}$ & $\begin{array}{c}\begin{array}{c}(10) \\
\text { no kids }\end{array} \\
\text { nat }\end{array}$ & $\begin{array}{l}\text { (11) } \\
\text { kids }\end{array}$ & $\begin{array}{c}\begin{array}{c}(12) \\
\text { healthy }\end{array} \\
\end{array}$ & $\begin{array}{c}(13) \\
\text { less healthy }\end{array}$ & $\begin{array}{c}\begin{array}{c}(14) \\
\text { renter }\end{array} \\
\end{array}$ & $\begin{array}{c}(15) \\
\text { owner }\end{array}$ & $\begin{array}{l}(16) \\
\text { poor }\end{array}$ & $\begin{array}{l}\text { (17) } \\
\text { rich }\end{array}$ & $\begin{array}{l}(18) \\
\text { city }\end{array}$ & $\begin{array}{c}\begin{array}{c}(19) \\
\text { suburb }\end{array} \\
\text { subs }\end{array}$ & $\begin{array}{l}(20) \\
\text { rural }\end{array}$ & $\begin{array}{l}(21) \\
\text { mobile }\end{array}$ & $\begin{array}{l}\begin{array}{l}(22) \\
\text { stuck }\end{array} \\
\end{array}$ & $\begin{array}{c}(23) \\
\text { rooted }\end{array}$ \\
\hline income & $6.482^{* * *}$ & $7.392^{* * *}$ & $5.746^{* * *}$ & $6.280^{* * *}$ & $6.827^{* * *}$ & $6.064^{* * *}$ & $7.167^{* * *}$ & $5.518^{* * *}$ & $7.494^{* * *}$ & $6.525^{* * *}$ & $5.847 * * *$ & $6.217^{* * *}$ & $6.694^{* * *}$ & $6.630^{* * *}$ & $6.986 * * *$ & $5.726^{* * * *}$ & $7.255^{* * *}$ & $5.306^{*}$ & 6.630 & $6.734^{* * *}$ & $5.746^{\circ}$ & $7.242 * * *$ & 7.218 \\
\hline homecost & $\begin{aligned} & (0.353) * \\
-7.284^{* * *} & (058)\end{aligned}$ & $\begin{array}{c}(0.847) \\
-7.843^{* * *}\end{array}$ & $\begin{array}{l}(0.785) \\
-5.932^{* * *} \\
(051)\end{array}$ & $\begin{array}{l}(0.5577) \\
-7.331^{* * *} \\
\end{array}$ & $\begin{array}{l}(0.899) \\
-6.279^{* * *} \\
0\end{array}$ & $\begin{array}{c}(0.912) \\
-6.370^{* * *}\end{array}$ & $\begin{array}{l}(0.664) \\
-7.765^{* * *}\end{array}$ & $\begin{array}{l}(0.769) \\
-7.110^{* * *}\end{array}$ & $\begin{array}{c}(0.575) \\
-7.195^{* * *}\end{array}$ & $\begin{array}{c}(0.680) \\
-6.931^{* * *}\end{array}$ & $\begin{array}{c}(0.705) \\
-6.935^{* * * *}\end{array}$ & $\begin{array}{c}(0.512) \\
-7.622^{* * *}\end{array}$ & $\begin{array}{r}(0.611) \\
-6.024^{* * *}\end{array}$ & $\begin{array}{l}(0.680) \\
-7.088^{* * *}\end{array}$ & $\begin{array}{l}(0.556) \\
-7.135 * * *\end{array}$ & $\begin{array}{l}(0.741) \\
-7.002^{* * *}\end{array}$ & $\begin{array}{l}(0.843) \\
-7.264^{* * *}\end{array}$ & $\begin{array}{c}(0.867) \\
-6.239^{* * *}\end{array}$ & $\begin{array}{c}(0.656) \\
-6.398 * * *\end{array}$ & $\begin{array}{l}857) \\
29 * * *\end{array}$ & 7899) & $\begin{array}{c}(0.935) \\
-9.353^{* * *}\end{array}$ & $\begin{array}{c}(1.158) \\
-6.521^{* * *}\end{array}$ \\
\hline crime & $\begin{array}{c}-1.013^{* * *} \\
(0.050)\end{array}$ & $\begin{array}{c}-1.049^{* * *} \\
(0.110)\end{array}$ & $\begin{array}{c}(0.9734) \\
(0.054)\end{array}$ & $\begin{array}{c}(0.483) \\
-0.960^{* * *} \\
(0.055)\end{array}$ & $\begin{array}{c}-1.0615) \\
(0.080 * * \\
(0.98)\end{array}$ & $\begin{array}{c}(0.732) \\
-0.912^{* * *} \\
(0.078)\end{array}$ & $\begin{array}{c}(1.001) \\
-1.083 * * \\
(0.093)\end{array}$ & $\begin{array}{c}(0.977) \\
-0.942^{* * *} \\
(0.080)\end{array}$ & $\begin{array}{c}(0.754) \\
-1.081 * * * \\
(0.119)\end{array}$ & $\begin{array}{c}(0.786) \\
-1.046 * * \\
(0.074)\end{array}$ & $\begin{array}{c}(0.624) \\
-0.997^{* * *} \\
(0.091)\end{array}$ & $\begin{array}{c}(0.718) \\
-1.039 * * \\
(0.090)\end{array}$ & $\begin{array}{c}(0.837) \\
-0.946 * * \\
(0.047)\end{array}$ & $\begin{array}{c}(0.674) \\
-0.946 * * \\
(0.067)\end{array}$ & $\begin{array}{c}(0.619) \\
-1.048^{* * *} \\
(0.047)\end{array}$ & $\begin{array}{c}(0.570) \\
-0.977^{* * *} \\
(0.049)\end{array}$ & $\begin{array}{c}(0.820) \\
-1.034^{* * *} \\
(0.093)\end{array}$ & $\begin{array}{c}(1.132) \\
-0.851 * * \\
(0.144)\end{array}$ & $\begin{array}{c}(1.000) \\
-1.003 * * \\
(0.102)\end{array}$ & $\begin{array}{c}(0.920) \\
-1.135 * * * \\
(0.255)\end{array}$ & $\begin{array}{c}(0.524) \\
-0.906^{* * *} \\
(0.062)\end{array}$ & $\begin{array}{c}(1.002) \\
-1.183^{* * *} \\
(0.199)\end{array}$ & $\begin{array}{c}(1.219) \\
-1.134^{* * *}\end{array}$ \\
\hline dist & $\begin{array}{c}-0.083^{* * *} \\
(0.013)\end{array}$ & $\begin{array}{c}-0.106 * * * * \\
(0.012)\end{array}$ & $\begin{array}{c}-0.082^{* * * *} \\
(0.016)\end{array}$ & $\begin{array}{c}-0.088 * * * \\
(0.011)\end{array}$ & $\begin{array}{c}-0.129^{* * *} \\
(0.019)\end{array}$ & $\begin{array}{c}-0.1011^{* * *} \\
(0.017)\end{array}$ & $\begin{array}{c}-0.094 * * * \\
(0.013)\end{array}$ & $\begin{array}{c}-0.089^{* * *} \\
(0.010)\end{array}$ & $\begin{array}{c}-0.094^{* * * *} \\
(0.015)\end{array}$ & $\begin{array}{c}-0.114^{* * *} \\
(0.010)\end{array}$ & $\begin{array}{c}-0.074^{* * *} \\
(0.014)\end{array}$ & $\begin{array}{c}-0.077^{* * * *} \\
(0.008)\end{array}$ & $\begin{array}{c}-0.1111^{* * * *} \\
(0.006)\end{array}$ & $\begin{array}{c}-0.0955^{* * *} \\
(0.011)\end{array}$ & $\begin{array}{c}-0.094 * * * \\
(0.014)\end{array}$ & $\begin{array}{c}-0.098^{* * *} \\
(0.014)\end{array}$ & $\begin{array}{c}-0.0988^{* * *} \\
(0.015)\end{array}$ & $\begin{array}{c}-0.068 * * * \\
(0.015)\end{array}$ & $\begin{array}{c}-0.084^{* * *} \\
(0.013)\end{array}$ & $\begin{array}{c}-0.115^{* * * *} \\
(0.013)\end{array}$ & $\begin{array}{c}-0.067^{* * * *} \\
(0.010)\end{array}$ & $\begin{array}{c}-0.0888^{* * *} \\
(0.015)\end{array}$ & $\begin{array}{c}-0.185^{* * * *} \\
(0.031)\end{array}$ \\
\hline family & $\begin{array}{c}0.955^{* * *} \\
(0.071)\end{array}$ & $\begin{array}{c}1.128^{* * *} \\
(0.136)\end{array}$ & $\begin{array}{c}0.852^{* * *} \\
(0.120)\end{array}$ & $\begin{array}{c}0.814^{* * *} \\
(0.069)\end{array}$ & $\begin{array}{c}1.1777^{* * *} \\
(0.128)\end{array}$ & $\begin{array}{c}0.769 * * * \\
(0.116)\end{array}$ & $\begin{array}{c}1.060^{* * *} \\
(0.095)\end{array}$ & $\begin{array}{c}0.700^{* * *} \\
(0.110)\end{array}$ & $\begin{array}{c}1.128^{* * *} \\
(0.100)\end{array}$ & $\begin{array}{c}0.961^{* * *} \\
(0.107)\end{array}$ & $\begin{array}{c}0.855 * * * \\
(0.101)\end{array}$ & $\begin{array}{c}0.888^{* * *} \\
(0.076)\end{array}$ & $\begin{array}{c}1.096^{* * *} \\
(0.070)\end{array}$ & $\begin{array}{c}0.8411^{* * *} \\
(0.135)\end{array}$ & $\begin{array}{c}1.059^{* * *} \\
(0.114)\end{array}$ & $\begin{array}{c}0.726^{* * *} \\
(0.097)\end{array}$ & $\begin{array}{c}1.080^{* * *} \\
(0.111)\end{array}$ & $\begin{array}{c}0.733 * * * \\
(0.126)\end{array}$ & $\begin{array}{c}0.954 * * * \\
(0.105)\end{array}$ & $\begin{array}{c}1.079^{* * *} \\
(0.123)\end{array}$ & $\begin{array}{c}0.827 * * \\
(0.104)\end{array}$ & $\begin{array}{c}0.997^{* * *} \\
(0.111)\end{array}$ & $\begin{array}{c}1.425^{* * *} \\
(0.190)\end{array}$ \\
\hline size & $\begin{array}{c}0.008 \\
(0.052)\end{array}$ & $\begin{array}{c}0.059 \\
(0.077)\end{array}$ & $\begin{array}{l}-0.001 \\
(0.086)\end{array}$ & $\begin{array}{c}0.230^{* * *} \\
(0.067)\end{array}$ & $\begin{array}{l}-0.033 \\
(0.031)\end{array}$ & $\begin{array}{l}-0.020 \\
(0.038)\end{array}$ & $\begin{array}{c}0.058 \\
(0.081)\end{array}$ & $\begin{array}{c}0.113^{* *} \\
(0.057)\end{array}$ & $\begin{array}{l}0.006 \\
(0.054)\end{array}$ & $\begin{array}{l}-0.024 \\
(0.036)\end{array}$ & $\begin{array}{c}0.051 \\
(0.105)\end{array}$ & $\begin{array}{c}0.009 \\
(0.030)\end{array}$ & $\begin{array}{l}0.079 \\
(0.090)\end{array}$ & $\begin{array}{c}0.329^{* * *} \\
(0.077)\end{array}$ & $\begin{array}{l}0.015 \\
(0.036)\end{array}$ & $\begin{array}{l}0.030 \\
(0.048)\end{array}$ & $\begin{array}{l}0.048 \\
(0.052)\end{array}$ & $\begin{array}{c}0.075 \\
(0.084)\end{array}$ & $\begin{array}{c}0.038 \\
(0.086)\end{array}$ & $\begin{array}{l}-0.023 \\
(0.045)\end{array}$ & $\begin{array}{l}-0.020 \\
(0.036)\end{array}$ & $\begin{array}{c}0.362^{* * *} \\
(0.109)\end{array}$ & $\begin{array}{l}-0.035 \\
(0.060)\end{array}$ \\
\hline mvcost & $\begin{array}{c}-0.048^{* * * *} \\
(0.003)\end{array}$ & $\begin{array}{c}-0.051 * * * \\
(0.009)\end{array}$ & $\begin{array}{c}-0.056^{* * * *} \\
(0.007)\end{array}$ & $\begin{array}{c}-0.060^{* * * *} \\
(0.007)\end{array}$ & $\begin{array}{c}-0.061^{* * *} \\
(0.009)\end{array}$ & $\begin{array}{c}-0.046^{* * * *} \\
(0.007)\end{array}$ & $\begin{array}{c}-0.056^{* * *} \\
(0.009)\end{array}$ & $\begin{array}{c}-0.051^{* * * *} \\
(0.005)\end{array}$ & $\begin{array}{c}-0.057 * * * \\
(0.007)\end{array}$ & $\begin{array}{c}-0.053^{* * *} \\
(0.005)\end{array}$ & $\begin{array}{c}-0.048^{* * * *} \\
(0.011)\end{array}$ & $\begin{array}{c}-0.048 * * * \\
(0.004)\end{array}$ & $\begin{array}{c}-0.058^{* * *} \\
(0.006)\end{array}$ & $\begin{array}{c}-0.069 * * * \\
(0.008)\end{array}$ & $\begin{array}{c}-0.054^{* * *} \\
(0.006)\end{array}$ & $\begin{array}{c}-0.049 * * * \\
(0.005)\end{array}$ & $\begin{array}{c}-0.054^{* * *} \\
(0.007)\end{array}$ & $\begin{array}{c}-0.045^{* * *} \\
(0.009)\end{array}$ & $\begin{array}{c}-0.052^{* * *} \\
(0.008)\end{array}$ & $\begin{array}{c}-0.053^{* * *} * \\
(0.008)\end{array}$ & $\begin{array}{c}-0.045 * * * \\
(0.005)\end{array}$ & $\begin{array}{c}-0.073 * * \\
(0.012)\end{array}$ & $\begin{array}{c}-0.066^{* * *} \\
(0.010)\end{array}$ \\
\hline taxes & $\begin{array}{c}-0.130^{* * * *} \\
(0.007)\end{array}$ & $\begin{array}{c}-0.145^{* * * *} \\
(0.015)\end{array}$ & $\begin{array}{c}-0.123 * * * \\
(0.014)\end{array}$ & $\begin{array}{c}-0.123^{* * * *} \\
(0.010)\end{array}$ & $\begin{array}{c}-0.154^{* * * *} \\
(0.015)\end{array}$ & $\begin{array}{c}-0.116^{* * *} \\
(0.012)\end{array}$ & $\begin{array}{c}-0.138 * * * \\
(0.013)\end{array}$ & $\begin{array}{c}-0.139 * * * \\
(0.009)\end{array}$ & $\begin{array}{c}-0.134 * * * \\
(0.011)\end{array}$ & $\begin{array}{c}-0.129 * * * \\
(0.014)\end{array}$ & $\begin{array}{c}-0.139 * * * \\
(0.011)\end{array}$ & $\begin{array}{c}-0.118^{* * * *} \\
(0.013)\end{array}$ & $\begin{array}{c}-0.153^{* * * *} \\
(0.015)\end{array}$ & $\begin{array}{c}-0.116^{* * * *} \\
(0.010)\end{array}$ & $\begin{array}{c}-0.147^{* * *} \\
(0.010)\end{array}$ & $\begin{array}{c}-0.132 * * * \\
(0.016)\end{array}$ & $\begin{array}{c}-0.140^{* * * *} \\
(0.012)\end{array}$ & $\begin{array}{c}-0.110^{* * * *} \\
(0.015)\end{array}$ & $\begin{array}{c}-0.124^{* * * *} \\
(0.009)\end{array}$ & $\begin{array}{c}-0.201 * * * \\
(0.020)\end{array}$ & $\begin{array}{c}-0.107 * * * \\
(0.013)\end{array}$ & $\begin{array}{c}-0.132 * * * \\
(0.021)\end{array}$ & $\begin{array}{c}-0.153^{* * *} \\
(0.018)\end{array}$ \\
\hline norms & $\begin{array}{c}0.646^{* * *} \\
(0.032)\end{array}$ & $\begin{array}{c}0.599^{* * *} \\
(0.069)\end{array}$ & $\begin{array}{c}0.737 * * * \\
(0.063)\end{array}$ & $\begin{array}{c}0.541^{* * *} \\
(0.051)\end{array}$ & $\begin{array}{c}0.811^{* * *} \\
(0.048)\end{array}$ & $\begin{array}{c}0.6433^{* * *} \\
(0.062)\end{array}$ & $\begin{array}{c}0.681^{* * *} \\
(0.054)\end{array}$ & $\begin{array}{c}0.526^{* * *} \\
(0.053)\end{array}$ & $\begin{array}{c}0.772^{* * *} \\
(0.047)\end{array}$ & $\begin{array}{c}0.741^{* * *} \\
(0.048)\end{array}$ & $\begin{array}{c}0.560^{* * *} \\
(0.075)\end{array}$ & $\begin{array}{c}0.650 * * * \\
(0.050)\end{array}$ & $\begin{array}{c}0.670^{* * *} \\
(0.051)\end{array}$ & $\begin{array}{c}0.607 * * * \\
(0.064)\end{array}$ & $\begin{array}{c}0.726^{* * *} \\
(0.062)\end{array}$ & $\begin{array}{c}0.534^{* * *} \\
(0.063)\end{array}$ & $\begin{array}{c}0.782^{* * *} \\
(0.062)\end{array}$ & $\begin{array}{c}0.576^{* * * *} \\
(0.077)\end{array}$ & $\begin{array}{c}0.670^{* * *} \\
(0.049)\end{array}$ & $\begin{array}{c}0.849^{* * *} \\
(0.126)\end{array}$ & $\begin{array}{c}0.613^{* * *} \\
(0.055)\end{array}$ & $\begin{array}{c}0.627^{* * *} \\
(0.096)\end{array}$ & $\begin{array}{c}0.758^{* * *} \\
(0.079)\end{array}$ \\
\hline o.moved & 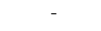 & 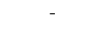 & & 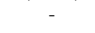 & . & - & 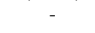 & $=0$ & & - & 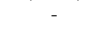 & 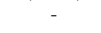 & 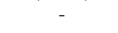 & . & & 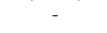 & 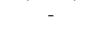 & . & & 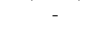 & - & - & 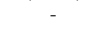 \\
\hline 3.altnum & $\begin{array}{c}0.311^{* * *} \\
(0.025)\end{array}$ & $\begin{array}{c}0.337 * * * \\
(0.056)\end{array}$ & $\begin{array}{c}0.415 * * * \\
(0.058)\end{array}$ & $\begin{array}{c}0.328 * * \\
(0.049)\end{array}$ & $\begin{array}{c}0.438 * * * \\
(0.085)\end{array}$ & $\begin{array}{c}0.290 * * * \\
(0.055)\end{array}$ & $\begin{array}{c}0.378 * * * \\
(0.089)\end{array}$ & $\begin{array}{c}0.305 * * \\
(0.050)\end{array}$ & $\begin{array}{c}0.376 * * * \\
(0.069)\end{array}$ & $\begin{array}{c}0.355 * * * \\
(0.058)\end{array}$ & $\begin{array}{c}0.318 * * * \\
(0.075)\end{array}$ & $\begin{array}{c}0.327^{* * *} \\
(0.038)\end{array}$ & $\begin{array}{c}0.364^{* * *} \\
(0.052)\end{array}$ & $\begin{array}{c}0.335 * * * \\
(0.060)\end{array}$ & $\begin{array}{c}0.373^{* * *} \\
(0.062)\end{array}$ & $\begin{array}{c}0.317^{* * *} \\
(0.051)\end{array}$ & $\begin{array}{c}0.376 * * * \\
(0.081)\end{array}$ & $\begin{array}{c}0.268^{* * *} \\
(0.049)\end{array}$ & $\begin{array}{c}0.377^{* * *} \\
(0.047)\end{array}$ & $\begin{array}{c}0.345^{* * *} \\
(0.085)\end{array}$ & $\begin{array}{c}0.296 * * * \\
(0.040)\end{array}$ & $\begin{array}{c}0.401 * * * \\
(0.060)\end{array}$ & $\begin{array}{c}0.488 * * * \\
(0.096)\end{array}$ \\
\hline Constant & $\begin{array}{c}-0.286^{* * * *} \\
(0.021)\end{array}$ & $\begin{array}{c}-0.279 * * * \\
(0.032)\end{array}$ & $\begin{array}{c}-0.336^{* * *} \\
(0.034)\end{array}$ & $\begin{array}{c}-0.246 * * * \\
(0.021)\end{array}$ & $\begin{array}{c}-0.380 \text { *** } \\
(0.061)\end{array}$ & $\begin{array}{c}-0.285 * * * \\
(0.043)\end{array}$ & $\begin{array}{c}-0.307 * * * \\
(0.040)\end{array}$ & $\begin{array}{c}-0.247^{* * * *} \\
(0.031)\end{array}$ & $\begin{array}{c}-0.338 * * * * \\
(0.036)\end{array}$ & $\begin{array}{c}-0.329 * * * \\
(0.036)\end{array}$ & $\begin{array}{c}-0.263^{* * * *} \\
(0.027)\end{array}$ & $\begin{array}{c}-0.285^{* * * *} \\
(0.028)\end{array}$ & $\begin{array}{c}-0.311 * * * \\
(0.030)\end{array}$ & $\begin{array}{c}-0.250 * * * \\
(0.030)\end{array}$ & $\begin{array}{c}-0.319 * * * \\
(0.038)\end{array}$ & $\begin{array}{c}-0.278 * * * \\
(0.037)\end{array}$ & $\begin{array}{c}-0.301 * * * * \\
(0.035)\end{array}$ & $\begin{array}{c}-0.233^{* * * *} \\
(0.027)\end{array}$ & $\begin{array}{c}-0.295^{* * * *} \\
(0.027)\end{array}$ & $\begin{array}{c}-0.328 * * * \\
(0.051)\end{array}$ & $\begin{array}{c}-0.281 * * * \\
(0.031)\end{array}$ & $\begin{array}{c}-0.285^{* * *} \\
(0.031)\end{array}$ & $\begin{array}{c}-0.413 * * * \\
(0.046)\end{array}$ \\
\hline Observations & 17,808 & 8,672 & 9,136 & 8,272 & 9,536 & 6,480 & 11,328 & 7,920 & 9,888 & 10,672 & 7,136 & 10,416 & 7,376 & 5,056 & 12,752 & 7,824 & 9,984 & 3,952 & 8,320 & 5,536 & 7,168 & 2,288 & 8,352 \\
\hline
\end{tabular}




\section{B Survey instrument}

Our data were collected in January 2018 and September 2018 using supplemental questions to the Survey of Consumer Expectations. The SCE core questionnaire can be found here. Some supplemental questions were asked in both January and September, while others were specific to each.

\section{B.1 Supplemental questions asked in both waves}

Qmv1. How many years have you lived at your current primary residence (that is, the place where you usually live)?

year $(\mathrm{s})$

Qmv1a. What is the approximate size of your current primary residence? square feet

Qmv2. Which of the following best describes where you live? Please select only one.

1. City center/urban area

2. Suburb less than 20 miles from a city center

3. Suburb 20 miles or more from a city center

4. In a small town

5. In a rural area

6. Other

[If $A g e>4+Q m v 1]$ Qmv3. Where did you live before moving to your current residence? Please select only one.

I lived in:

1. The same state and county where I currently reside

2. The same state but a different county than were I currently reside

3. A different state than where I currently reside

4. Another country

[If $Q m \boldsymbol{m} 3=3]$ Qmv4. In which state was your previous primary residence? 
Qmv7. We would now like you to think about your future moving plans. What is the percent chance that over the next 2 years (January 2018 to January 2020) you will move to a different primary residence?

Please enter your answer by clicking on the scale below or entering your response in the box to the right of the scale.

Percent

[If $\left(Q m v^{7}>=1\right)$ ] Qmv14. If you were to move to a different primary residence over the next 2 years, what is the percent chance that this home would be in: lanswers need to add to 100]

Within 10 miles of where you currently reside

Between 10 and 100 miles of where you currently reside

Between 100 and 500 miles of where you currently reside

More than 500 miles of where you currently reside percent percent , percent percent

[If $\left(Q m v^{7}>=1\right)$ ] Qmv15. And if you were to move to a different primary residence over the next 2 years, what is the percent chance that you or your spouse/partner would buy (as opposed to rent) your new home?

Please enter your answer by clicking on the scale below or entering your response in the box to the right of the scale.

Percent

Asked at the very end of the survey: Qmv11. To what extent do you agree or disagree with the following statements?

In order to avoid unemployment I would be willing to move within America.

\begin{tabular}{|c|c|c|c|c|}
\hline $\begin{array}{c}1 . \\
\begin{array}{c}\text { Strongly } \\
\text { disagree }\end{array}\end{array}$ & $\begin{array}{c}2 . \\
\text { Somewhat } \\
\text { disagree }\end{array}$ & $\begin{array}{c}3 . \text { Neither } \\
\text { agree nor } \\
\text { disagree }\end{array}$ & $\begin{array}{c}4 . \\
\text { Somewhat } \\
\text { agree }\end{array}$ & $\begin{array}{c}5 . \\
\text { Strongly } \\
\text { agree }\end{array}$ \\
\hline
\end{tabular}

[on same screen/ Even more so than a few decades ago, moving is the best way for many people to improve their lives

\begin{tabular}{|c|c|c|c|c|}
\hline $\begin{array}{c}\text { Strongly } \\
\text { disagree }\end{array}$ & $\begin{array}{c}2 . \\
\text { Somewhat } \\
\text { disagree }\end{array}$ & $\begin{array}{c}\text { 3. Neither } \\
\text { agree nor } \\
\text { disagree }\end{array}$ & $\begin{array}{c}4 . \\
\text { Somewhat } \\
\text { agree }\end{array}$ & $\begin{array}{c}5 . \\
\text { Strongly } \\
\text { agree }\end{array}$ \\
\hline
\end{tabular}

[on same screen] Even more so than a few decades ago, to pursue better job opportunities one needs to move

\begin{tabular}{|c|c|c|c|c|}
\hline $\begin{array}{c}\text { Strongly } \\
\text { disagree }\end{array}$ & $\begin{array}{c}2 . \\
\text { Somewhat } \\
\text { disagree }\end{array}$ & $\begin{array}{c}\text { 3. Neither } \\
\text { agree nor } \\
\text { disagree }\end{array}$ & $\begin{array}{c}4 . \\
\text { Somewhat } \\
\text { agree }\end{array}$ & $\begin{array}{c}5 . \\
\text { Strongly } \\
\text { agree }\end{array}$ \\
\hline
\end{tabular}

Qmv12. In terms of your ability and willingness to move, which of the following best 
describes your situation? Please select only one.

- Mobile - am open to, and able to move if an opportunity comes along

- Stuck - would like to move but am trapped in place and unable to move

- Rooted - am strongly embedded in my community and don't want to move

\section{B.2 January-only questions}

Qmv10. Here are some reasons for why people may not want to move. Please indicate the importance to you of each of these reasons for not moving to a different primary residence over the next 2 years?

If a factor does not apply to you, rate the factor as not important at all. 


\begin{tabular}{|c|c|c|c|c|c|}
\hline & $\begin{array}{l}\text { Not at all } \\
\text { important }\end{array}$ & $\begin{array}{c}\text { A little } \\
\text { important }\end{array}$ & $\begin{array}{l}\text { Somewhat } \\
\text { important }\end{array}$ & $\begin{array}{c}\text { Very } \\
\text { important }\end{array}$ & $\begin{array}{l}\text { Extremely } \\
\text { important }\end{array}$ \\
\hline \multicolumn{6}{|l|}{$\begin{array}{l}\text { I like my current home / no reason to } \\
\text { move }\end{array}$} \\
\hline \multicolumn{6}{|l|}{ Can't afford the high costs of moving } \\
\hline \multicolumn{6}{|l|}{$\begin{array}{l}\text { Can't afford to buy a home in the places I } \\
\text { would like to move to }\end{array}$} \\
\hline \multicolumn{6}{|l|}{ Difficult to find a new place to move into } \\
\hline \multicolumn{6}{|l|}{$\begin{array}{l}\text { I cannot get the price I want for my } \\
\text { current home or sell for enough to pay off } \\
\text { my whole mortgage balance }\end{array}$} \\
\hline \multicolumn{6}{|l|}{$\begin{array}{l}\text { Have locked in a very low mortgage } \\
\text { interest rate and don't want to lose it }\end{array}$} \\
\hline \multicolumn{6}{|l|}{ Difficult to qualify for a new mortgage } \\
\hline \multicolumn{6}{|l|}{ I like my current job } \\
\hline \multicolumn{6}{|l|}{ Hard to find a job elsewhere } \\
\hline \multicolumn{6}{|l|}{$\begin{array}{l}\text { Iif married/have partner] Hard for spouse } \\
\text { to find a job elsewhere }\end{array}$} \\
\hline \multicolumn{6}{|l|}{ Am not licensed to work in other states } \\
\hline \multicolumn{6}{|l|}{$\begin{array}{l}\text { My work experience would be less } \\
\text { valuable / count for less elsewhere }\end{array}$} \\
\hline \multicolumn{6}{|l|}{$\begin{array}{l}\text { May lose Medicaid coverage if I move to } \\
\text { another state }\end{array}$} \\
\hline \multicolumn{6}{|l|}{$\begin{array}{l}\text { May lose unemployment or other welfare } \\
\text { benefits or receive less when moving out } \\
\text { of state }\end{array}$} \\
\hline \multicolumn{6}{|l|}{$\begin{array}{l}\text { Depend financially on local network or } \\
\text { local friends, family and church groups }\end{array}$} \\
\hline \multicolumn{6}{|l|}{ Have too much student debt } \\
\hline \multicolumn{6}{|l|}{$\begin{array}{l}\text { Have too much other debts or have not } \\
\text { saved enough }\end{array}$} \\
\hline \multicolumn{6}{|l|}{ Health reasons } \\
\hline \multicolumn{6}{|l|}{ Have children in school } \\
\hline \multicolumn{6}{|l|}{ Good quality of local school } \\
\hline \multicolumn{6}{|l|}{ Closeness to family and children } \\
\hline \multicolumn{6}{|l|}{$\begin{array}{l}\text { I like the neighborhood and climate where } \\
\text { I currently live }\end{array}$} \\
\hline \multicolumn{6}{|l|}{$\begin{array}{l}\text { Am very involved in local } \\
\text { community/church or share local cultural } \\
\text { values }\end{array}$} \\
\hline $\begin{array}{l}\text { Worry about higher crime rates in other } \\
\text { locations }\end{array}$ & & & & & \\
\hline
\end{tabular}

Qmv11. And here are some reasons for why people may want to move. Please indicate the importance to you of each of these reasons for moving to a different primary residence over the next 2 years?

If a factor does not apply to you, rate the factor as not important at all. 


\begin{tabular}{|c|c|c|c|c|c|}
\hline & $\begin{array}{l}\text { Not at all } \\
\text { important }\end{array}$ & $\begin{array}{c}\text { A little } \\
\text { important }\end{array}$ & $\begin{array}{l}\text { Somewhat } \\
\text { important }\end{array}$ & $\begin{array}{c}\text { Very } \\
\text { important }\end{array}$ & $\begin{array}{l}\text { Extremely } \\
\text { important }\end{array}$ \\
\hline \multicolumn{6}{|l|}{$\begin{array}{l}\text { Expect to be forced out current home by } \\
\text { landlord, bank other financial institution, or } \\
\text { government }\end{array}$} \\
\hline \multicolumn{6}{|l|}{ I do not like my current home } \\
\hline \multicolumn{6}{|l|}{ To upgrade to a larger or a better quality home } \\
\hline \multicolumn{6}{|l|}{ To reduce housing costs } \\
\hline \multicolumn{6}{|l|}{$\begin{array}{l}\text { To change from owning to renting OR renting } \\
\text { to owning }\end{array}$} \\
\hline \multicolumn{6}{|l|}{ A new job or job transfer } \\
\hline \multicolumn{6}{|l|}{$\begin{array}{l}\text { [if married/have partner] A new job or job } \\
\text { transfer of spouse/partner }\end{array}$} \\
\hline \multicolumn{6}{|l|}{ To attend an educational institution } \\
\hline \multicolumn{6}{|l|}{ To reduce commuting time to work/school } \\
\hline \multicolumn{6}{|l|}{ To look for a job } \\
\hline \multicolumn{6}{|l|}{$\begin{array}{l}\text { My work experience would be more valuable / } \\
\text { count for more elsewhere }\end{array}$} \\
\hline \multicolumn{6}{|l|}{$\begin{array}{l}\text { May gain Medicaid coverage if I move to } \\
\text { another state }\end{array}$} \\
\hline \multicolumn{6}{|l|}{$\begin{array}{l}\text { May gain unemployment or other welfare } \\
\text { benefits or receive more when moving out of } \\
\text { state }\end{array}$} \\
\hline \multicolumn{6}{|l|}{$\begin{array}{l}\text { Change in household or family size, including } \\
\text { marriage, divorce, separation, death, or child } \\
\text { birth or adoption }\end{array}$} \\
\hline \multicolumn{6}{|l|}{ Crowding, conflict, or violence in the household } \\
\hline \multicolumn{6}{|l|}{ Health reasons } \\
\hline \multicolumn{6}{|l|}{ Have too much student debt } \\
\hline \multicolumn{6}{|l|}{ Have too much other debts } \\
\hline \multicolumn{6}{|l|}{$\begin{array}{l}\text { To be closer to family and friends (including } \\
\text { for health reasons, economic reasons, or for any } \\
\text { other reasons) }\end{array}$} \\
\hline \multicolumn{6}{|l|}{$\begin{array}{l}\text { To be in a more desirable neighborhood or } \\
\text { climate }\end{array}$} \\
\hline \multicolumn{6}{|l|}{ To be in a safer neighborhood } \\
\hline \multicolumn{6}{|l|}{$\begin{array}{l}\text { To be in a better school district/have access to } \\
\text { better schools }\end{array}$} \\
\hline \multicolumn{6}{|l|}{$\begin{array}{l}\text { To have better access to public transportation, } \\
\text { such as bus, subway, or commuter train service. }\end{array}$} \\
\hline \multicolumn{6}{|l|}{$\begin{array}{l}\text { Access to public services like libraries, } \\
\text { playgrounds, and community centers }\end{array}$} \\
\hline \multicolumn{6}{|l|}{$\begin{array}{l}\text { Better access to amenities like restaurants, } \\
\text { theaters, shopping, and doctors' offices }\end{array}$} \\
\hline Cultural values in other places are too different & & & & & \\
\hline
\end{tabular}

We will next describe a set of different events or circumstances and would like you to think of how these may change your moving plans over the next two years.

[Randomize into 4 groups with group 1 answering block $A 1$ and B1, group 2 answering block A2 and B1, group 3 answering block A1 and B2 and group 4 answering block A2 and B2] 
For blocks A1 and A2 show at the top of each screen the following: Earlier you

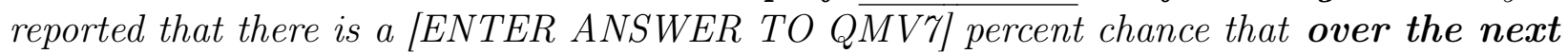
2 years (January 2018 to January 2020) you will move to a different primary residence.

\section{Block A1}

[show 14a-14b sequentially on same screen]

Qmv14a. Suppose that you won a lottery payout of $\$ 50,000$. What is the percent chance you would move to a new location over the next two years?

Please enter your answer by clicking on the scale below or entering your response in the box to the right of the scale.

\section{Percent}

Qmv14b. Suppose instead that you won a lottery payout of $\$ 500,000$. What is the percent chance you would move to a new location over the next two years?

Please enter your answer by clicking on the scale below or entering your response in the box to the right of the scale.

Percent

[show 15a-15d sequentially on same screen]

[If currently employed]

Qmv15a. Assume that during the next two years your employer relocates and offers you the option to keep your current job at a new location some 100-500 miles away, which would require you to move. Assume that the new location is very comparable to your current one, and that your cost-of-living adjusted wage is the same at this new location. What is the percent chance you would move to this new location over the next two years?

Please enter your answer by clicking on the scale below or entering your response in the box to the right of the scale.

Percent

[If currently employed]

Qmv15b. If the new location was instead more than 500 miles away, what is the percent chance you would move to this new location over the next two years?

Please enter your answer by clicking on the scale below or entering your response in the box to the right of the scale.

Percent

[If currently employed]

Qmv15c. If the new location was 100-500 miles away from where you currently live but your employer offered a $\mathbf{2 0 \%}$ salary increase, what is the percent chance you would move to this new location over the next two years?

Please enter your answer by clicking on the scale below or entering your response in the box to the right of the scale.

Percent 
[If currently employed]

Qmv15d. What if the new location was 100-500 miles away from where you currently live but your employer offered a $\mathbf{5 0 \%}$ salary increase, what is the percent chance you would move to this new location over the next two years?

Please enter your answer by clicking on the scale below or entering your response in the box to the right of the scale.

Percent

[show 16a-16c sequentially on same screen]

[If married/have partner and spouse employed]

Qmv16a. [if self currently employed] Now suppose instead that during the next two years /if self NOT currently employed/ Suppose that during the next two years your spouse's employer relocates and offers your spouse the option to keep his/her current job at a new location some 100-500 miles away, which would require you to move. Assume that the new location is very comparable to your current one, and that your spouse's cost-of-living adjusted wage is the same at this new location. What is the percent chance you would move to this new location over the next two years?

Please enter your answer by clicking on the scale below or entering your response in the box to the right of the scale.

Percent

[If married/have partner and spouse employed]

Qmv16b. What if your spouse's employer offered a $20 \%$ salary increase, what is the percent chance you would move to this new location over the next two years?

Please enter your answer by clicking on the scale below or entering your response in the box to the right of the scale.

Percent

[If married/have partner and spouse employed]

Qmv16c. And what if your spouse's employer offered a $50 \%$ salary increase, what is the percent chance you would move to this new location over the next two years?

Please enter your answer by clicking on the scale below or entering your response in the box to the right of the scale.

Percent

[show 17 on separate screen]

Qmv17. Now suppose instead that, if you moved at least 100 miles away from your current location, your extended family and friends who live in the current location would be able to move with you to the new location. What is the percent chance you would move to this new location over the next two years?

Please enter your answer by clicking on the scale below or entering your response in the box to the right of the scale.

Percent 


\section{Block A2}

[show 18a-18c sequentially on same screen]

Qmv18a. Suppose that you were given $\$ 5,000$ to put towards a move to a location that is 100-500 miles away from where you currently live. You could use this money for "box and truck" moving costs, termination of rental/mortgage agreements, or any other miscellaneous expenses incurred during relocation. What is the percent chance you would move to this new location over the next two years?

Please enter your answer by clicking on the scale below or entering your response in the box to the right of the scale.

Percent

Qmv18b. Now suppose instead that you were given $\$ \mathbf{1 0 , 0 0 0}$ to put towards a move to a location that is 100-500 miles away from where you currently live. You could use this money for "box and truck" moving costs, termination of rental/mortgage agreements, or any other miscellaneous expenses incurred during relocation. What is the percent chance you would move to this new location over the next two years?

Please enter your answer by clicking on the scale below or entering your response in the box to the right of the scale.

Percent

Qmv18c. Suppose again that you were given $\$ 10,000$ to put towards a move to a location that is instead more than $\mathbf{5 0 0}$ miles away from where you currently live. What is the percent chance you would move to this new location over the next two years?

Please enter your answer by clicking on the scale below or entering your response in the box to the right of the scale.

Percent

[show 19 a on separate screen]

[If own home]

Qmv19a. Now suppose instead that, if you moved at least 100 miles away from your current location, you would be able to sell your current home for at least as much as you purchased it for. What is the percent chance you would move to this new location over the next two years?

Please enter your answer by clicking on the scale below or entering your response in the box to the right of the scale.

Percent

[show $19 b$ on separate screen]

[If own home]

Qmv19b. Now suppose instead that, if you moved at least 100 miles away from your current location, you would be able to keep your exact dwelling and lot. (i.e. if it were possible to literally pick up and move your dwelling and lot to the new location). What is the percent chance you would move to this new location over the next two years?

Please enter your answer by clicking on the scale below or entering your response in the 
box to the right of the scale.

Percent

[show 19 c on separate screen]

[If own home]

Qmv19c. Now suppose instead that, if you moved at least 100 miles away from your current location, you would have the option to keep your same mortgage interest rate if you bought a new home in the new location. What is the percent chance you would move to this new location over the next two years?

Please enter your answer by clicking on the scale below or entering your response in the box to the right of the scale.

Percent

[show 19d on separate screen]

Qmv19d. Now suppose instead that, if you moved at least 100 miles away from your current location, your healthcare practitioner network would move with you to the new location. What is the percent chance you would move to this new location over the next two years?

Please enter your answer by clicking on the scale below or entering your response in the box to the right of the scale.

Percent

[show 19e on separate screen]

Qmv19e. Now suppose instead that, if you moved at least 100 miles away from your current location, your local schools would also move with you to the new location. What is the percent chance you would move to this new location over the next two years?

Please enter your answer by clicking on the scale below or entering your response in the box to the right of the scale.

Percent

\section{Block B1}

Qmv20. Suppose that you were forced to move today to a location some 200-500 miles away, and you had to decide which neighborhood to live in. You intend to stay there for at least 3 years. [if own home: Assume that you were able to sell your current primary residence today and pay off your outstanding mortgage (if you have one)].

In each of the 4 scenarios below, you will be shown hypothetical neighborhood characteristics, with each neighborhood characterized by:

Cost of housing

Local crime rate

Your household's income prospects 


\section{All neighborhoods are otherwise identical in all other aspects.}

In each scenario, you are given a choice among three neighborhoods and you will be asked for the percent chance (or chances out of 100) of choosing each. The chance of each alternative should be a number between 0 and 100 and the chances given to the three alternatives should add up to 100.

[show each scenario on new screen]

Scenario 1

$\begin{array}{llll}\text { Neighborhood } & \begin{array}{l}\text { Housing costs } \\ \text { compared to } \\ \text { current } \\ \text { location }\end{array} & \begin{array}{l}\text { Crime rate } \\ \text { compared to } \\ \text { current } \\ \text { location }\end{array} & \begin{array}{l}\text { Household } \\ \text { income } \\ \text { compared to } \\ \text { current } \\ \text { location }\end{array} \\ \text { A } & 10 \% \text { higher } & \begin{array}{l}\text { same } \\ \text { double }\end{array} & \begin{array}{l}\text { same } \\ \text { B }\end{array} \\ \text { C } & 10 \% \text { higher } \\ 6 \% \text { lower } & \text { half } & 6 \% \text { higher }\end{array}$

What is the percent chance that you choose to live in each neighborhood? [answers need to add to 100]

A _ percent chance

$\mathrm{B}$ __ percent chance

$\mathrm{C} \_$percent chance

Scenario 2

$\begin{array}{llll}\text { Neighborhood } & \begin{array}{l}\text { Housing costs } \\ \text { compared to } \\ \text { current } \\ \text { location }\end{array} & \begin{array}{l}\text { Crime rate } \\ \text { compared to } \\ \text { current } \\ \text { location }\end{array} & \begin{array}{l}\text { Household } \\ \text { income } \\ \text { compared to } \\ \text { current } \\ \text { location }\end{array} \\ \text { A } & \begin{array}{l}8 \% \text { higher } \\ \text { B }\end{array} & \text { half } & \begin{array}{l}5 \% \text { higher } \\ \text { C }\end{array} \\ 10 \% \text { higher } & \text { same } & 5 \% \text { higher } \\ \text { same }\end{array}$

What is the percent chance that you choose to live in each neighborhood? [answers need to add to 100]

A _ percent chance

$\mathrm{B}$ _ percent chance

$\mathrm{C} \_$percent chance

Scenario 3 


$\begin{array}{llll}\text { Neighborhood } & \begin{array}{l}\text { Housing costs } \\ \text { compared to } \\ \text { current } \\ \text { location }\end{array} & \begin{array}{l}\text { Crime rate } \\ \text { compared to } \\ \text { current } \\ \text { location }\end{array} & \begin{array}{l}\text { Household } \\ \text { income } \\ \text { compared to } \\ \text { current } \\ \text { location }\end{array} \\ \text { A } & \text { same } & \text { double } & 5 \% \text { lower } \\ \text { B } & 5 \% \text { lower } & \text { same } & \text { same } \\ \text { C } & 5 \% \text { higher } & \text { half } & \text { same }\end{array}$

What is the percent chance that you choose to live in each neighborhood? [answers need to add to 100]
A _ percent chance
$\mathrm{B}$ _ percent chance
$\mathrm{C}$ _ percent chance

\section{Scenario 4}

$\begin{array}{llll}\text { Neighborhood } & \begin{array}{l}\text { Housing costs } \\ \text { compared to } \\ \text { current } \\ \text { location }\end{array} & \begin{array}{l}\text { Crime rate } \\ \text { compared to } \\ \text { current } \\ \text { location }\end{array} & \begin{array}{l}\text { Household } \\ \text { income } \\ \text { compared to } \\ \text { current } \\ \text { location }\end{array} \\ \text { A } & \text { same } & \text { half } & 3 \% \text { lower } \\ \text { B } & \text { same } & \text { same } & \text { same } \\ \text { C } & 5 \% \text { higher } & \text { half } & 5 \% \text { higher }\end{array}$

What is the percent chance that you choose to live in each neighborhood? [answers need to add to 100]
A _ percent chance
$\mathrm{B}$ _ percent chance
$\mathrm{C}$ _ percent chance

Qmv21. Suppose again that you were forced to move today to a location some distance away, and you had to decide which neighborhood to live in. You intend to stay there for at least 3 years. [if own home: Assume that you were able to sell your current primary residence today and pay off your outstanding mortgage (if you have one)].

In each of the 4 scenarios below, you will be shown hypothetical neighborhood characteristics, with each neighborhood characterized by:

Your household's income prospects

Distance from your current location

Family and friends who live in current location moving with you to new location

All neighborhoods are otherwise identical in all other aspects, including costs of housing. 
In each scenario, you are given a choice among three neighborhoods and you will be asked for the percent chance (or chances out of 100) of choosing each. The chance of each alternative should be a number between 0 and 100 and the chances given to the three alternatives should add up to 100 .

[show each scenario on new screen]

Scenario 1

$\begin{array}{llll}\text { Neighborhood } & \begin{array}{l}\text { Household } \\ \text { income } \\ \text { compared to } \\ \text { current } \\ \text { location }\end{array} & \begin{array}{l}\text { Distance } \\ \text { (miles) from } \\ \text { current } \\ \text { location }\end{array} & \begin{array}{l}\text { Family and } \\ \text { friends move } \\ \text { to new } \\ \text { location }\end{array} \\ \text { A } & \begin{array}{l}\text { 10\% higher } \\ \text { same }\end{array} & 500 & \text { No } \\ \text { C } & 10 \% \text { lower } & 500 & \text { No } \\ \end{array}$

What is the percent chance that you choose to live in each neighborhood? [answers need to add to 100]

A _ percent chance

$\mathrm{B}$ _ percent chance

$\mathrm{C} \ldots$ percent chance

\section{Scenario 2}

$\begin{array}{llll}\text { Neighborhood } & \begin{array}{l}\text { Household } \\ \text { income } \\ \text { compared to } \\ \text { current } \\ \text { location }\end{array} & \begin{array}{l}\text { Distance } \\ \text { (miles) from } \\ \text { current } \\ \text { location }\end{array} & \begin{array}{l}\text { Family and } \\ \text { friends move } \\ \text { to new } \\ \text { location }\end{array} \\ \text { A } & 5 \% \text { lower } & 500 & \text { Yes } \\ \text { B } & \text { same } & 500 & \text { No } \\ \text { C } & 5 \% \text { lower } & 50 & \text { No }\end{array}$

What is the percent chance that you choose to live in each neighborhood? [answers need to add to 100]
A _ _ percent chance
$\mathrm{B}$ __ percent chance
$\mathrm{C}$ __ percent chance

\section{Scenario 3}

$\begin{array}{llll}\text { Neighborhood } & \begin{array}{l}\text { Household } \\ \text { income } \\ \text { compared to } \\ \text { current } \\ \text { location }\end{array} & \begin{array}{l}\text { Distance } \\ \text { (miles) from } \\ \text { current } \\ \text { location }\end{array} & \begin{array}{l}\text { Family and } \\ \text { friends move } \\ \text { to new } \\ \text { location }\end{array} \\ \text { A } & \begin{array}{l}5 \% \text { lower } \\ 10 \% \text { higher }\end{array} & 100 & \text { Yes } \\ \text { B } & 500 & \text { No } \\ \text { C } & 15 \% \text { higher } & 1000 & \text { No }\end{array}$


What is the percent chance that you choose to live in each neighborhood? [answers need to add to 100]
A _ percent chance
$\mathrm{B}$ _ percent chance
$\mathrm{C}$ _ percent chance

\section{Scenario 4}

\begin{tabular}{|c|c|c|c|}
\hline Neighborhood & $\begin{array}{l}\text { Household } \\
\text { income } \\
\text { compared to } \\
\text { current } \\
\text { location }\end{array}$ & $\begin{array}{l}\text { Distance } \\
\text { (miles) from } \\
\text { current } \\
\text { location }\end{array}$ & $\begin{array}{l}\text { Family and } \\
\text { friends move } \\
\text { to new } \\
\text { location }\end{array}$ \\
\hline A & same & 100 & Yes \\
\hline B & $2 \%$ higher & 500 & Yes \\
\hline $\mathrm{C}$ & $5 \%$ higher & 100 & No \\
\hline
\end{tabular}

What is the percent chance that you choose to live in each neighborhood? [answers need to add to 100]
A _ percent chance
$\mathrm{B}$ _ percent chance
$\mathrm{C}$ _ percent chance

\section{Block B2}

Qmv23. Suppose that you were forced to move today to a location some 200-500 miles away, and you had to decide which neighborhood to live in. You intend to stay there for at least 3 years. [if own home: Assume that you were able to sell your current primary residence today and pay off your outstanding mortgage (if you have one)].

In each of the 4 scenarios below, you will be shown hypothetical neighborhood characteristics, with each neighborhood characterized by:

Your household's income prospects

Home quality as measured by size of home (square foot)

Your costs of moving to new location

All neighborhoods are otherwise identical in all other aspects, including costs of housing.

[show each scenario on new screen]

Scenario 1 


$\begin{array}{llll}\text { Neighborhood } & \begin{array}{l}\text { Household } \\ \text { income } \\ \text { compared to } \\ \text { current } \\ \text { location }\end{array} & \begin{array}{l}\text { Home size (sq } \\ \mathbf{f t} \text { ) compared } \\ \text { to current } \\ \text { dwelling }\end{array} & \begin{array}{l}\text { "Box and } \\ \text { Truck" } \\ \text { moving costs }\end{array} \\ \text { A } & \begin{array}{l}\text { 8\% higher } \\ \text { same }\end{array} & \begin{array}{l}500 \text { smaller } \\ \text { same }\end{array} & \$ 10,000 \\ \text { C } & 8 \% \text { lower } & 1000 \text { larger } & \$ 10,000\end{array}$

What is the percent chance that you choose to live in each neighborhood? [answers need to add to 100]
A _ percent chance
$\mathrm{B}$ _ percent chance
$\mathrm{C}$ __ percent chance

\section{Scenario 2}

$\begin{array}{llll}\text { Neighborhood } & \begin{array}{l}\text { Household } \\ \text { income } \\ \text { compared to } \\ \text { current }\end{array} & \begin{array}{l}\text { Home size (sq } \\ \text { ft) compared } \\ \text { to current } \\ \text { dwelling }\end{array} & \begin{array}{l}\text { "Box and } \\ \text { Truck" } \\ \text { moving costs }\end{array} \\ \text { location } & \text { 50 smaller } & \$ 1,500 \\ \text { A } & \begin{array}{l}4 \% \text { higher } \\ \text { same }\end{array} & \text { same } & \$ 4,000 \\ \text { C } & 4 \% \text { lower } & 1000 \text { larger } & \$ 6,500\end{array}$

What is the percent chance that you choose to live in each neighborhood? [answers need to add to 100]
A _ percent chance
$\mathrm{B}$ _ percent chance
$\mathrm{C}$ _ percent chance

Scenario 3

$\begin{array}{llll}\text { Neighborhood } & \begin{array}{l}\text { Household } \\ \text { income } \\ \text { compared to } \\ \text { current }\end{array} & \begin{array}{l}\text { Home size (sq } \\ \text { ft) compared } \\ \text { to current } \\ \text { dwelling }\end{array} & \begin{array}{l}\text { "Box and } \\ \text { Truck" } \\ \text { moving costs }\end{array} \\ \text { A } & \begin{array}{l}5 \% \text { lower } \\ 10 \% \text { higher }\end{array} & \begin{array}{l}\text { 1000 larger } \\ \text { same }\end{array} & \$ 4,000 \\ \text { C } & 15 \% \text { higher } & \text { same } & \$ 14,000\end{array}$

What is the percent chance that you choose to live in each neighborhood? [answers need to add to 100]
A _ percent chance
$\mathrm{B}$ _ percent chance 
$\mathrm{C} \_$percent chance

Scenario 4

$\begin{array}{llll}\text { Neighborhood } & \begin{array}{l}\text { Household } \\ \text { income } \\ \text { compared to } \\ \text { current } \\ \text { location }\end{array} & \begin{array}{l}\text { Home size (sq } \\ \text { ft) compared } \\ \text { to current } \\ \text { dwelling }\end{array} & \begin{array}{l}\text { "Box and } \\ \text { Truck" } \\ \text { moving costs }\end{array} \\ \text { A } & \text { same } & 500 \text { larger } & \$ 2,000 \\ \text { B } & 5 \% \text { higher } & 1000 \text { larger } & \$ 8,000 \\ \text { C } & \text { same } & \$ 15,000\end{array}$

What is the percent chance that you choose to live in each neighborhood? [answers need to add to 100]
A _ percent chance
$\mathrm{B} \_$percent chance
$\mathrm{C} \_$percent chance

Qmv24. Suppose again that you were forced to move today to a location some 200-500 miles away, and you had to decide which neighborhood to live in. You intend to stay there for at least 3 years. [if homeowner: Assume that you were able to sell your current primary residence today and pay off your outstanding mortgage].

In each of the 4 scenarios below, you will be shown hypothetical neighborhood characteristics, with each neighborhood characterized by:

Your household's income prospects

State and local taxes

Cultural values and norms

All neighborhoods are otherwise identical in all other aspects, including costs of housing.

Scenario 1

Neighborhood

B

C

Household
income
compared to
current
location
$10 \%$ higher
same
$10 \%$ lower

State \& local
taxes
compared to
current
location
$5 \%$ higher
$5 \%$ lower
same

Cultural values \& norms compared to current location

less agreeable to my values same more agreeable to my values 
What is the percent chance that you choose to live in each neighborhood? [answers need to add to 100]
A _ percent chance
$\mathrm{B}$ _ percent chance
$\mathrm{C}$ _ percent chance

\section{Scenario 2}

$\begin{array}{llll}\text { Neighborhood } & \begin{array}{l}\text { Household } \\ \text { income } \\ \text { compared to } \\ \text { current } \\ \text { location }\end{array} & \begin{array}{l}\text { State \& local } \\ \text { taxes } \\ \text { compared to } \\ \text { current } \\ \text { location } \\ \text { same }\end{array} & \begin{array}{l}\text { Cultural values \& } \\ \text { norms compared to } \\ \text { current location }\end{array} \\ \text { A } & \text { same } & 5 \% \text { higher } & \begin{array}{l}\text { less agreeable to my } \\ \text { values } \\ \text { more agreeable to my } \\ \text { values } \\ \text { same }\end{array} \\ \text { B } & 5 \% \text { lower } & \text { same } & \end{array}$

What is the percent chance that you choose to live in each neighborhood? [answers need to add to 100]

A _ percent chance

$\mathrm{B}$ _ percent chance

$\mathrm{C}$ _ percent chance

Scenario 3

\begin{tabular}{|c|c|c|c|}
\hline Neighborhood & $\begin{array}{l}\text { Household } \\
\text { income } \\
\text { compared to } \\
\text { current } \\
\text { location }\end{array}$ & $\begin{array}{l}\text { State \& local } \\
\text { taxes } \\
\text { compared to } \\
\text { current } \\
\text { location }\end{array}$ & $\begin{array}{l}\text { Cultural values \& } \\
\text { norms compared to } \\
\text { current location }\end{array}$ \\
\hline A & $5 \%$ lower & $5 \%$ higher & $\begin{array}{l}\text { less agreeable to my } \\
\text { values }\end{array}$ \\
\hline B & $10 \%$ higher & $5 \%$ lower & same \\
\hline $\mathrm{C}$ & $15 \%$ higher & same & $\begin{array}{l}\text { more agreeable to my } \\
\text { values }\end{array}$ \\
\hline
\end{tabular}

What is the percent chance that you choose to live in each neighborhood? [answers need to add to 100]

A _ percent chance

$\mathrm{B}$ _ percent chance

$\mathrm{C}$ _ percent chance

Scenario 4 


$\begin{array}{llll}\text { Neighborhood } & \begin{array}{l}\text { Household } \\ \text { income } \\ \text { compared to } \\ \text { current } \\ \text { location } \\ \text { same }\end{array} & \begin{array}{l}\text { State \& local } \\ \text { taxes } \\ \text { compared to } \\ \text { current } \\ \text { location } \\ \text { same }\end{array} & \begin{array}{l}\text { Cultural values \& } \\ \text { norms compared to } \\ \text { current location }\end{array} \\ \text { A } & \text { same } & 5 \% \text { lower } & \begin{array}{l}\text { more agreeable to my } \\ \text { values } \\ \text { same } \\ \text { less agreeable to my } \\ \text { v }\end{array} \\ 5 \% \text { higher } & 5 \% \text { higher } & \begin{array}{l}\text { values } \\ \text { C }\end{array}\end{array}$

What is the percent chance that you choose to live in each neighborhood? [answers need to add to 100]

A _ percent chance

$\mathrm{B}$ _ percent chance

$\mathrm{C}$ _ percent chance

[End of Block B2]

\section{B.3 September-only questions}

Qmv0. Do you or your spouse/partner own your primary residence? By primary residence, we mean the place where you usually live. Please select only one.

1. Yes

2. No

Qmv5. Do you currently live within 50 miles of an immediate or extended family member? Please select only one.

1. Yes

2. No

Qmv6. How would you rate the cultural values and norms of people in your neighborhood/town (relative to your own values and norms)

\begin{tabular}{|c|c|c|c|c|}
\hline $\begin{array}{c}\text { 1. Highly } \\
\text { disagree- } \\
\text { able }\end{array}$ & $\begin{array}{c}2 . \\
\text { Somewhat } \\
\text { disagree- } \\
\text { able }\end{array}$ & $\begin{array}{c}3 . \text { Neither } \\
\text { agreeable } \\
\text { nor dis- } \\
\text { agreeable }\end{array}$ & $\begin{array}{c}4 . \\
\text { Somewhat } \\
\text { agreeable }\end{array}$ & $\begin{array}{c}\text { 5. Highly } \\
\text { agreeable }\end{array}$ \\
\hline
\end{tabular}

Qmv6a. Approximately what percentage of their income do households on average spend on combined state and local income, sales and property taxes where you currently reside? $\%$ 
We will next describe a set of different events or circumstances and would like you to think of how these may change your moving plans over the next two years. [Randomize into 2 groups with group 1 answering Cases 1,3,4,6, group 2 answering Cases 1,2,3,5]

Case 1. Suppose that you [and your household] were offered a few different opportunities to move over the next two years, and you had to decide whether to take any of the offers or to continue living at your current location. The offers to move are contingent on you staying there for at least 3 years. Note that in some scenarios the conditions in your current location (such as household income and the crime rate) may change as well. [if own; Assume that, if you were to move, you would be able to sell your current primary residence today and pay off your outstanding mortgage (if you have one)]. Neighborhood A represents your current location.

In each of the 4 scenarios below, you will be shown three locations to live in where each is characterized by:

Distance between this location and your current location

The crime rate in the area compared to the current crime rate in the area you live today

Your household's income prospects compared to your current income

Suppose that the locations are otherwise identical in all other aspects to your current location, including the cost of housing.

In each scenario, you are given a choice among three neighborhoods and you will be asked for the percent chance (or chances out of 100) of choosing each.

What is the percent chance that you choose to live in each neighborhood?

The chance of each alternative should be a number between 0 and 100 and the chances given to the three alternatives should add up to 100 .

\section{Scenario 1}

$\begin{array}{ll}\text { Neighborhood } & \begin{array}{l}\text { Distance } \\ \text { (miles) from }\end{array} \\ \text { current } \\ \text { location }\end{array}$

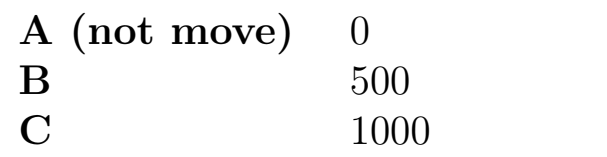

$\begin{array}{ll}\begin{array}{l}\text { Crime rate } \\ \text { compared to } \\ \text { current crime } \\ \text { rate }\end{array} & \begin{array}{l}\text { Household income } \\ \text { compared to current } \\ \text { income }\end{array} \\ \text { same } & \text { same } \\ \text { double } & 20 \% \text { higher } \\ \text { half } & 10 \% \text { higher }\end{array}$

What is the percent chance that you choose to live in each neighborhood? [answers need to add to 100]
A _ percent chance
$\mathrm{B}$ _ percent chance
$\mathrm{C}$ _ percent chance

\section{Scenario 2}




$\begin{array}{llll}\text { Neighborhood } & \begin{array}{l}\text { Distance } \\ \text { (miles) from } \\ \text { current } \\ \text { location }\end{array} & \begin{array}{l}\text { Crime rate } \\ \text { compared to } \\ \text { current crime } \\ \text { rate }\end{array} & \begin{array}{l}\text { Household income } \\ \text { compared to current } \\ \text { income }\end{array} \\ \text { A (not move) } & 0 & \text { same } & \text { same } \\ \text { B } & 500 & \text { same } & 5 \% \text { higher } \\ \text { C } & 500 & \text { half } & \text { same }\end{array}$

What is the percent chance that you choose to live in each neighborhood? [answers need to add to 100]

$\mathrm{A} \_$percent chance
$\mathrm{B} \_$percent chance
$\mathrm{C} \_$percent chance

Scenario 3

$\begin{array}{llll}\text { Neighborhood } & \begin{array}{l}\text { Distance } \\ \text { (miles) from } \\ \text { current } \\ \text { location }\end{array} & \begin{array}{l}\text { Crime rate } \\ \text { compared to } \\ \text { current crime } \\ \text { rate }\end{array} & \begin{array}{l}\text { Household income } \\ \text { compared to current } \\ \text { income }\end{array} \\ \text { A (not move) } & 0 & \text { same } & 15 \% \text { lower } \\ \text { B } & 500 & \text { half } & 10 \% \text { lower } \\ \text { C } & 1000 & \text { double } & 5 \% \text { higher }\end{array}$

What is the percent chance that you choose to live in each neighborhood? [answers need to add to 100]

$\mathrm{A} \_$percent chance
$\mathrm{B} \_$percent chance
$\mathrm{C} \_$percent chance

Scenario 4

$\begin{array}{llll}\text { Neighborhood } & \begin{array}{l}\text { Distance } \\ \text { (miles) from } \\ \text { current } \\ \text { location }\end{array} & \begin{array}{l}\text { Crime rate } \\ \text { compared to } \\ \text { current crime } \\ \text { rate }\end{array} & \begin{array}{l}\text { Household income } \\ \text { compared to current } \\ \text { income }\end{array} \\ \text { A (not move) } & 0 & \text { same } & 20 \% \text { lower } \\ \text { B } & 500 & \text { half } & \text { same } \\ \text { C } & 1000 & \text { half } & 5 \% \text { higher }\end{array}$

What is the percent chance that you choose to live in each neighborhood? [answers need to add to 100]

A _ percent chance

$\mathrm{B}$ __ percent chance

$\mathrm{C}$ _ percent chance 
Case 2. Suppose again that you [and your household] were offered a few different opportunities to move over the next two years, and you had to decide whether to take any of the offers or to continue living at your current location. The offers to move are contingent on you staying there for at least 3 years. Note that in some scenarios the conditions in your current location (such as household income) may change as well. [if own; Assume that, if you were to move, you would be able to sell your current primary residence today and pay off your outstanding mortgage (if you have one)]. Neighborhood A represents your current location.

In each of the 4 scenarios below, you will be shown three locations to live in where each is characterized by:

Distance from your current location

A subsidy to cover your costs of moving to new location

Your household's income prospects

Suppose that the locations are otherwise identical in all other aspects to your current location, including the cost of housing.

In each scenario, you are given a choice among three neighborhoods and you will be asked for the percent chance (or chances out of 100) of choosing each.

What is the percent chance that you choose to live in each neighborhood?

The chance of each alternative should be a number between 0 and 100 and the chances given to the three alternatives should add up to 100 .

\section{Scenario 1}

$\begin{array}{llll}\text { Neighborhood } & \begin{array}{l}\text { Distance } \\ \text { (miles) from } \\ \text { current } \\ \text { location }\end{array} & \begin{array}{l}\text { "Box and } \\ \text { Truck" } \\ \text { moving costs }\end{array} & \begin{array}{l}\text { Household income } \\ \text { compared to current } \\ \text { income }\end{array} \\ \text { A (not move) } & 0 & \$ 0 & \text { same } \\ \text { B } & 500 & \$ 10,000 & 20 \% \text { higher } \\ \text { C } & 1000 & \$ 15,000 & 20 \% \text { higher }\end{array}$

What is the percent chance that you choose to live in each neighborhood? [answers need to add to 100]

A _ percent chance

$\mathrm{B}$ _ percent chance

$\mathrm{C} \_$percent chance

\section{Scenario 2}




$\begin{array}{llll}\text { Neighborhood } & \begin{array}{l}\text { Distance } \\ \text { (miles) from } \\ \text { current } \\ \text { location }\end{array} & \begin{array}{l}\text { "Box and } \\ \text { Truck" } \\ \text { moving costs }\end{array} & \begin{array}{l}\text { Household income } \\ \text { compared to current } \\ \text { income }\end{array} \\ \text { A (not move) } & 0 & \$ 0 & \text { same } \\ \text { B } & 500 & \$ 15,000 & \text { same } \\ \text { C } & 1000 & \$ 15,000 & 10 \% \text { higher }\end{array}$

What is the percent chance that you choose to live in each neighborhood? [answers need to add to 100]

A _ percent chance

$\mathrm{B}$ _ percent chance

$\mathrm{C} \_$percent chance

\section{Scenario 3}

$\begin{array}{llll}\text { Neighborhood } & \begin{array}{l}\text { Distance } \\ \text { (miles) from } \\ \text { current } \\ \text { location }\end{array} & \begin{array}{l}\text { "Box and } \\ \text { Truck" } \\ \text { moving costs }\end{array} & \begin{array}{l}\text { Household income } \\ \text { compared to current } \\ \text { income }\end{array} \\ \text { A (not move) } & 0 & \$ 0 & \text { same } \\ \text { B } & 500 & \$ 15,000 & 15 \% \text { higher } \\ \text { C } & 300 & \$ 10,000 & 5 \% \text { higher }\end{array}$

What is the percent chance that you choose to live in each neighborhood? [answers need to add to 100]

$\mathrm{A} \_$percent chance
$\mathrm{B} \_$percent chance
$\mathrm{C} \_$percent chance

Scenario 4

$\begin{array}{llll}\text { Neighborhood } & \begin{array}{l}\text { Distance } \\ \text { (miles) from } \\ \text { current } \\ \text { location }\end{array} & \begin{array}{l}\text { "Box and } \\ \text { Truck" } \\ \text { moving costs }\end{array} & \begin{array}{l}\text { Household income } \\ \text { compared to current } \\ \text { income }\end{array} \\ \text { A (not move) } & 0 & \$ 0 & \text { same } \\ \text { B } & 500 & \$ 30,000 & 30 \% \text { higher } \\ \text { C } & 1000 & \$ 10,000 & 10 \% \text { higher }\end{array}$

What is the percent chance that you choose to live in each neighborhood? [answers need to add to 100]
A _ percent chance
$\mathrm{B}$ _ percent chance
$\mathrm{C}$ _ percent chance 
Case 3. Suppose again that you [and your household] were offered a few different opportunities to move over the next two years, and you had to decide whether to take any of the offers or to continue living at your current location. The offers to move are contingent on you staying there for at least 3 years. Note that in some scenarios the conditions in your current location (such as household income and whether your family and friends live nearby) may change as well (for example because you or your family and friends move to a different location). [if own; Assume that, if you were to move, you would be able to sell your current primary residence today and pay off your outstanding mortgage (if you have one)]. Neighborhood A represents your current location.

In each of the 4 scenarios below, you will be shown three locations to live in where each is characterized by:

Distance from your current location

Family and friends live nearby this location

Your household's income prospects

Suppose that the locations are otherwise identical in all other aspects to your current location, including the cost of housing.

In each scenario, you are given a choice among three neighborhoods and you will be asked for the percent chance (or chances out of 100) of choosing each.

What is the percent chance that you choose to live in each neighborhood?

The chance of each alternative should be a number between 0 and 100 and the chances given to the three alternatives should add up to 100 .

\section{Scenario 1}

$\begin{array}{llll}\text { Neighborhood } & \begin{array}{l}\text { Distance } \\ \text { (miles) from } \\ \text { current } \\ \text { location }\end{array} & \begin{array}{l}\text { Family and } \\ \text { friends live in } \\ \text { this location }\end{array} & \begin{array}{l}\text { Household income } \\ \text { compared to current } \\ \text { income }\end{array} \\ \text { A (not move) } & 0 & \text { No } & 10 \% \text { lower } \\ \text { B } & 1000 & \text { Yes } & \text { same } \\ \text { C } & 1000 & \text { No } & 10 \% \text { higher }\end{array}$

What is the percent chance that you choose to live in each neighborhood? [answers need to add to 100]

A _ percent chance

$\mathrm{B}$ __ percent chance

$\mathrm{C} \_$_ percent chance

\section{Scenario 2}




$\begin{array}{llll}\text { Neighborhood } & \begin{array}{l}\text { Distance } \\ \text { (miles) from } \\ \text { current } \\ \text { location }\end{array} & \begin{array}{l}\text { Family and } \\ \text { friends live in } \\ \text { this location }\end{array} & \begin{array}{l}\text { Household income } \\ \text { compared to current } \\ \text { income }\end{array} \\ \text { A (not move) } & 0 & \text { Yes } & 10 \% \text { lower } \\ \text { B } & 500 & \text { Yes } & 50 \% \text { higher } \\ \text { C } & 100 & \text { No } & 20 \% \text { higher }\end{array}$

What is the percent chance that you choose to live in each neighborhood? [answers need to add to 100]
A _ percent chance
$\mathrm{B}$ _ percent chance
$\mathrm{C}$ _ percent chance

Scenario 3

$\begin{array}{llll}\text { Neighborhood } & \begin{array}{l}\text { Distance } \\ \text { (miles) from } \\ \text { current } \\ \text { location }\end{array} & \begin{array}{l}\text { Family and } \\ \text { friends live in } \\ \text { this location }\end{array} & \begin{array}{l}\text { Household income } \\ \text { compared to current } \\ \text { income }\end{array} \\ \text { A (not move) } & 0 & \text { No } & 5 \% \text { lower } \\ \text { B } & 250 & \text { Yes } & 10 \% \text { higher } \\ \text { C } & 10 & \text { Yes } & 20 \% \text { lower }\end{array}$

What is the percent chance that you choose to live in each neighborhood? [answers need to add to 100]
A _ percent chance
$\mathrm{B}$ _ percent chance
$\mathrm{C}$ _ percent chance

Scenario 4

$\begin{array}{llll}\text { Neighborhood } & \begin{array}{l}\text { Distance } \\ \text { (miles) from } \\ \text { current } \\ \text { location }\end{array} & \begin{array}{l}\text { Family and } \\ \text { friends live in } \\ \text { this location }\end{array} & \begin{array}{l}\text { Household income } \\ \text { compared to current } \\ \text { income }\end{array} \\ \text { A (not move) } & 0 & \text { Yes } & 15 \% \text { lower } \\ \text { B } & 350 & \text { Yes } & \begin{array}{l}\text { same } \\ 100 \% \text { higher (i.e. } \\ \text { d }\end{array} \\ 500 & \text { No } & \text { double) }\end{array}$

What is the percent chance that you choose to live in each neighborhood? [answers need to add to 100]
A _ percent chance
$\mathrm{B}$ _ percent chance
$\mathrm{C}$ _ percent chance 
Case 4. Suppose again that you [and your household] were offered a few different opportunities to move over the next two years, and you had to decide whether to take any of the offers or to continue living at your current location. The offers to move are contingent on you staying there for at least 3 years. Note that in some scenarios the conditions in your current location (such as household income or cultural values and norms in your neighborhood/town) may change as well. [if own; Assume that, if you were to move, you would be able to sell your current primary residence today and pay off your outstanding mortgage (if you have one)]. Neighborhood A represents your current location.

In each of the 4 scenarios below, you will be shown three locations to live in where each is characterized by:

Distance from your current location

Cultural values and norms

Cost of housing

Suppose that the locations are otherwise identical in all other aspects to your current location, except that in addition to the differences shown below both neighborhood $B$ and $C$ your household income will be $10 \%$ higher than your current income.

In each scenario, you are given a choice among three neighborhoods and you will be asked for the percent chance (or chances out of 100) of choosing each.

What is the percent chance that you choose to live in each neighborhood?

The chance of each alternative should be a number between 0 and 100 and the chances given to the three alternatives should add up to 100 .

\section{Scenario 1}

$\begin{array}{ll}\text { Neighborhood } & \begin{array}{l}\text { Distance } \\ \text { (miles) from }\end{array} \\ \text { current } \\ \text { location }\end{array}$

A (not move) 0

B

C 500

\begin{tabular}{|c|c|}
\hline $\begin{array}{l}\text { Cultural } \\
\text { values and } \\
\text { norms } \\
\text { compared to } \\
\text { current neigh- } \\
\text { borhood/town }\end{array}$ & $\begin{array}{l}\text { Housing costs } \\
\text { compared to current } \\
\text { location }\end{array}$ \\
\hline same & same \\
\hline $\begin{array}{l}\text { more agreeable } \\
\text { to my values }\end{array}$ & $10 \%$ lower \\
\hline same & $20 \%$ lower \\
\hline
\end{tabular}

What is the percent chance that you choose to live in each neighborhood? [answers need to add to 100]

A _ percent chance

$\mathrm{B}$ __ percent chance

$\mathrm{C}$ _ percent chance

\section{Scenario 2}




$\begin{array}{llll}\text { Neighborhood } & \begin{array}{l}\text { Distance } \\ \text { (miles) from } \\ \text { current } \\ \text { location }\end{array} & \begin{array}{l}\text { Cultural } \\ \text { values and } \\ \text { norms } \\ \text { compared to } \\ \text { current neigh- } \\ \text { borhood } / \text { town }\end{array} & \begin{array}{l}\text { Housing costs } \\ \text { compared to current } \\ \text { location }\end{array} \\ \text { A (not move) } & 0 & \begin{array}{l}\text { same } \\ \text { more agreeable } \\ \text { to my values }\end{array} & \begin{array}{l}\text { same } \\ \text { B }\end{array} \\ \text { S } & 500 & \text { same lower } & 30 \% \text { higher }\end{array}$

What is the percent chance that you choose to live in each neighborhood? [answers need to add to 100]
A _ percent chance
$\mathrm{B}$ _ percent chance
$\mathrm{C}$ _ percent chance

\section{Scenario 3}

$\begin{array}{llll}\text { Neighborhood } & \begin{array}{l}\text { Distance } \\ \text { (miles) from } \\ \text { current } \\ \text { location }\end{array} & \begin{array}{l}\text { Cultural } \\ \text { values and } \\ \text { norms } \\ \text { compared to } \\ \text { current neigh- } \\ \text { borhood } / \text { town }\end{array} & \begin{array}{l}\text { Housing costs } \\ \text { compared to current } \\ \text { location }\end{array} \\ \text { same } & \text { same } \\ \text { more agreeable } & 50 \% \text { lower } \\ \text { B (not move) } & 0 & \begin{array}{l}\text { to my values } \\ \text { less agreeable to } \\ \text { my values }\end{array} & \text { same } \\ \text { C } & 600 & & \end{array}$

What is the percent chance that you choose to live in each neighborhood? [answers need to add to 100]
A _ percent chance
$\mathrm{B}$ _ percent chance
$\mathrm{C}$ _ percent chance

\section{Scenario 4}




$\begin{array}{llll}\text { Neighborhood } & \begin{array}{l}\text { Distance } \\ \text { (miles) from } \\ \text { current } \\ \text { location }\end{array} & \begin{array}{l}\text { Cultural } \\ \text { values and } \\ \text { norms } \\ \text { compared to } \\ \text { current neigh- } \\ \text { borhood } / \text { town } \\ \text { same }\end{array} & \begin{array}{l}\text { Housing costs } \\ \text { compared to current } \\ \text { location }\end{array} \\ \text { A (not move) } & 0 & \begin{array}{l}\text { less agreeable to } \\ \text { my values } \\ \text { more agreeable }\end{array} & 20 \% \text { lower } \\ \text { B } & 500 & \text { to my values } & \\ \text { C } & 300 & & \end{array}$

What is the percent chance that you choose to live in each neighborhood? [answers need to add to 100]

$\mathrm{A}$ _ percent chance
$\mathrm{B}$ _ percent chance
$\mathrm{C}$ _ percent chance

Case 5. Suppose again that you [and your household] were offered a few different opportunities to move over the next two years, and you had to decide whether to take any of the offers or to continue living at your current location. The offers to move are contingent on you staying there for at least 3 years. Note that in some scenarios the conditions in your current location (such as household income) may change as well. [if own; Assume that, if you were to move, you would be able to sell your current primary residence today and pay off your outstanding mortgage (if you have one)]. Neighborhood A represents your current location.

In each of the 4 scenarios below, you will be shown three locations to live in where each is characterized by:

Your household's income prospects

Home size

Your costs of moving to new location

Suppose that the locations are otherwise identical in all other aspects to your current location, and assume that neighborhoods B and C are both about 250 miles away your current location.

In each scenario, you are given a choice among three neighborhoods and you will be asked for the percent chance (or chances out of 100) of choosing each.

What is the percent chance that you choose to live in each neighborhood?

The chance of each alternative should be a number between 0 and 100 and the chances given to the three alternatives should add up to 100 . 
Scenario 1

$\begin{array}{llll}\text { Neighborhood } & \begin{array}{l}\text { Houshold } \\ \text { income } \\ \text { compared to } \\ \text { current } \\ \text { income }\end{array} & \begin{array}{l}\text { Home size (sq } \\ \text { ft) compared } \\ \text { to current } \\ \text { dwelling }\end{array} & \begin{array}{l}\text { "Box and truck" } \\ \text { moving costs }\end{array} \\ \text { A (not move) } & \text { same } & \text { same } & \$ 0 \\ \text { B } & 8 \% \text { higher } & 500 \text { smaller } & \$ 2,000 \\ \text { C } & 8 \% \text { lower } & 1000 \text { larger } & \$ 10,000\end{array}$

What is the percent chance that you choose to live in each neighborhood? [answers need to add to 100]

A _ percent chance

$\mathrm{B}$ __ percent chance

$\mathrm{C}$ _ percent chance

Scenario 2

$\begin{array}{llll}\text { Neighborhood } & \begin{array}{l}\text { Houshold } \\ \text { income } \\ \text { compared to } \\ \text { current } \\ \text { income }\end{array} & \begin{array}{l}\text { Home size (sq } \\ \text { ft) compared } \\ \text { to current } \\ \text { dwelling }\end{array} & \begin{array}{l}\text { "Box and truck" } \\ \text { moving costs }\end{array} \\ \text { same } & \text { same } & \$ 0 \\ \text { A (not move) } & 2 \% \text { higher } & 500 \text { smaller } & \$ 2,000 \\ \text { B } & 12 \% \text { higher } & 500 \text { smaller } & \$ 10,000\end{array}$

What is the percent chance that you choose to live in each neighborhood? [answers need to add to 100]

A _ percent chance

$\mathrm{B}$ _ percent chance

$\mathrm{C}$ _ percent chance

Scenario 3

$\begin{array}{llll}\text { Neighborhood } & \begin{array}{l}\text { Houshold } \\ \text { income } \\ \text { compared to } \\ \text { current } \\ \text { income }\end{array} & \begin{array}{l}\text { Home size (sq } \\ \text { ft) compared } \\ \text { to current } \\ \text { dwelling }\end{array} & \begin{array}{l}\text { "Box and truck" } \\ \text { moving costs }\end{array} \\ \text { same } & \text { same } & \$ 0 \\ \text { A (not move) } & \begin{array}{l}10 \% \text { higher } \\ \text { B }\end{array} & \begin{array}{l}1000 \text { larger } \\ \text { C }\end{array} & \$ 15,000 \\ & 10 \% \text { higher } & 500 \text { larger } & \$ 4,000\end{array}$

What is the percent chance that you choose to live in each neighborhood? [answers need to add to 100]

A _ percent chance 
$\mathrm{B}$ _ percent chance

$\mathrm{C}$ _ percent chance

\section{Scenario 4}

$\begin{array}{llll}\text { Neighborhood } & \begin{array}{l}\text { Houshold } \\ \text { income } \\ \text { compared to } \\ \text { current } \\ \text { income }\end{array} & \begin{array}{l}\text { Home size (sq } \\ \text { ft) compared } \\ \text { to current } \\ \text { dwelling }\end{array} & \begin{array}{l}\text { "Box and truck" } \\ \text { moving costs }\end{array} \\ \text { A (not move) } & \text { same } & \$ 0 \\ \text { B } & 8 \% \text { higher } & 200 \text { smaller } & \$ 6,000 \\ \text { C } & 8 \% \text { lower } & 100 \text { larger } & \$ 6,000\end{array}$

What is the percent chance that you choose to live in each neighborhood? [answers need to add to 100]

A _ percent chance

$\mathrm{B}$ _ percent chance

$\mathrm{C} \ldots$ percent chance

Case 6. Suppose again that you [and your household] were offered a few different opportunities to move over the next two years, and you had to decide whether to take any of the offers or to continue living at your current location. The offers to move are contingent on you staying there for at least 3 years. Note that in some scenarios the conditions in your current location (such as household income and state and local tax rates) may change as well. [if own; Assume that, if you were to move, you would be able to sell your current primary residence today and pay off your outstanding mortgage (if you have one)]. Neighborhood A represents your current location.

In each of the 4 scenarios below, you will be shown three locations to live in where each is characterized by:

Distance from current location

State \& local income, sales, and property taxes (as a percentage of income) compared to current location

Your household's income prospects

\section{Suppose that the locations are otherwise identical in all other aspects to your current location.}

In each scenario, you are given a choice among three neighborhoods and you will be asked for the percent chance (or chances out of 100) of choosing each.

What is the percent chance that you choose to live in each neighborhood?

The chance of each alternative should be a number between 0 and 100 and the chances given to the three alternatives should add up to 100 . 
Scenario 1

$\begin{array}{llll}\text { Neighborhood } & \begin{array}{l}\text { Distance } \\ \text { (miles) from } \\ \text { current } \\ \text { location }\end{array} & \begin{array}{l}\text { State \& local } \\ \text { tax rate } \\ \text { compared to } \\ \text { current rate }\end{array} & \begin{array}{l}\text { Before-tax household } \\ \text { income compared to } \\ \text { current income }\end{array} \\ \text { A (not move) } & 0 & 5 \text { percent higher } & \text { same } \\ \text { B } & 150 & \text { same } & 10 \% \text { higher } \\ \text { C } & 250 & \text { same } & 10 \% \text { lower }\end{array}$

What is the percent chance that you choose to live in each neighborhood? [answers need to add to 100]

A _ percent chance

$\mathrm{B}$ __ percent chance

$\mathrm{C}$ _ percent chance

\section{Scenario 2}

$\begin{array}{llll}\text { Neighborhood } & \begin{array}{l}\text { Distance } \\ \text { (miles) from } \\ \text { current }\end{array} & \begin{array}{l}\text { State \& local } \\ \text { tax rate } \\ \text { compared to } \\ \text { current rate }\end{array} & \begin{array}{l}\text { Before-tax household } \\ \text { income compared to } \\ \text { current income }\end{array} \\ \text { A (not move) } & 0 & \text { same } & \text { same } \\ \text { B } & 150 & 5 \text { percent lower } & \text { same } \\ \text { C } & 550 & 5 \text { percent lower } & 10 \% \text { higher }\end{array}$

What is the percent chance that you choose to live in each neighborhood? [answers need to add to 100]
A _ percent chance
$\mathrm{B}$ _ percent chance
$\mathrm{C}$ _ percent chance

Scenario 3

$\begin{array}{llll}\text { Neighborhood } & \begin{array}{l}\text { Distance } \\ \text { (miles) from } \\ \text { current } \\ \text { location }\end{array} & \begin{array}{l}\text { State \& local } \\ \text { tax rate } \\ \text { compared to } \\ \text { current rate }\end{array} & \begin{array}{l}\text { Before-tax household } \\ \text { income compared to } \\ \text { current income }\end{array} \\ \text { A (not move) } & 0 & \begin{array}{l}\text { same } \\ 10 \text { percent } \\ \text { higher }\end{array} & \begin{array}{l}\text { same } \\ 15 \% \text { higher }\end{array} \\ \text { B } & 250 & \text { same } & 5 \% \text { higher }\end{array}$

What is the percent chance that you choose to live in each neighborhood? [answers need to add to 100]

A _ percent chance

B _ percent chance 
C _ _ percent chance

Scenario 4

$\begin{array}{ll}\text { Neighborhood } & \begin{array}{l}\text { Distance } \\ \text { (miles) from } \\ \text { current } \\ \text { location }\end{array} \\ \text { A (not move) } & 0 \\ \text { B } & 550 \\ \text { C } & 100\end{array}$

State \& local Before-tax household

tax rate

compared to

income compared to

current rate

same same

5 percent lower $10 \%$ higher

5 percent higher $10 \%$ higher

What is the percent chance that you choose to live in each neighborhood? [answers need to add to 100]

A _ percent chance

$\mathrm{B}$ __ percent chance

$\mathrm{C} \_$percent chance 